\title{
New Square-Pyramidal Oxovanadium (IV) Complexes Derived from Polydentate Ligand $\left(\mathrm{L}^{1}\right)$
}

\author{
Azza A. Hassoon ${ }^{1}$, Najlaa S. Al-Radadi², Nagwa Nawar ${ }^{1}$, Mohsen M. Mostafa ${ }^{{ }^{*}}$ \\ ${ }^{1}$ Chemistry Department, Faculty of Science, Mansoura University, Egypt \\ ${ }^{2}$ Chemistry Department, Faculty of Science, Taibah University, Al-Madinah, Saudia Arabia \\ Email: "amohsenmostafa@yahoo.com
}

Received 5 October 2015; accepted 12 January 2016; published 15 January 2016

Copyright (C) 2016 by authors and Scientific Research Publishing Inc.

This work is licensed under the Creative Commons Attribution International License (CC BY). http://creativecommons.org/licenses/by/4.0/

(c) (i) Open Access

\begin{abstract}
New series of oxovanadium (IV) complexes isolated from 2,4,6-tris-(2-pyridyl)-1,3,5-triazine ( $\mathrm{L}^{1}$ ) are incorporated and portrayed using spectroscopic (IR, UV-Vis, ESR, mass spectrometric), magnetic moment, thermal and cyclic voltammetry measurements. The results demonstrate that $\mathrm{L}^{1}$ acts in various styles of chelation with $\left.\left[\mathrm{V}_{3} \mathrm{O}_{3}\left(\mathrm{~L}^{1}\right)\left(\mathrm{SO}_{4}\right)_{3}(\mathrm{EtOH})_{1 / 2}\left(\mathrm{H}_{2} \mathrm{O}\right)_{3 / 2}\right] 1\right)$, [VO( $\left.\mathrm{L}^{1}\right)(2,4$-pentadionate)] $\left.\left.\mathrm{Cl} \cdot 4 \mathrm{HCl} 2),\left[\mathrm{V}_{2} \mathrm{O}_{2}\left(\mathrm{~L}^{1}\right)\left(\mathrm{SO}_{4}\right)_{2}(\mathrm{EtOH})_{5 / 2}\right] 3\right),\left[\mathrm{V}_{2} \mathrm{O}_{2}\left(\mathrm{~L}^{1}\right)\left(\mathrm{SO}_{4}\right)_{2}(\mathrm{EtOH})_{3 / 2}\left(\mathrm{H}_{2} \mathrm{O}\right)_{1 / 2}\right] 4\right),\left[\mathrm{VO}\left(\mathrm{L}^{1}\right) \mathrm{SO}_{4}\right.$ $\left.\left.\left(\mathrm{H}_{2} \mathrm{O}\right)_{3 / 2}\right] \cdot 2.5 \mathrm{H}_{2} \mathrm{O} 5\right)$ and $\left[\mathrm{V}_{2} \mathrm{O}_{2}\left(\mathrm{~L}^{1}\right)\left(\mathrm{SO}_{4}\right)_{2}\left(\mathrm{H}_{2} \mathrm{O}\right)\right] \cdot \mathrm{H}_{2} \mathrm{O}$ 6). The values of magnetic moments and spectral studies suggest a square-pyramidal geometry around the $V$ (IV) ion for all complexes. The molar conductance values suggest that the complexes are non-electrolyte, except the [VO $\left(\mathrm{L}^{1}\right)(2,4-$ pentadionate)] $\mathrm{Cl} \cdot 4 \mathrm{HCl}$. Molecular modeling calculates the bond length, bond angle, chemical reactivity, energy components (Kcal/mol) and binding energy (Kcal/mol) for the isolated complexes. The in vitro antibacterial studies of these complexes screened against pathogenic bacteria prove them as growth inhibiting agents. Antitumor activity is carried out in vitro on human mammary gland (breast) MCF-7 and cervical cancer cell-HeLa has shown that $\left[\mathrm{VO}\left(\mathrm{L}^{1}\right) \mathrm{SO}_{4}\left(\mathrm{H}_{2} \mathrm{O}\right)_{3 / 2}\right] \cdot 2.5 \mathrm{H}_{2} \mathrm{O}$ and $\left[\mathrm{VO}\left(\mathrm{L}^{1}\right)(2,4\right.$-pentadionate $\left.)\right] \mathrm{Cl} \cdot 4 \mathrm{HCl}$ complexes display the highest powerful activity between all of the investigated complexes.
\end{abstract}

\section{Keywords}

Oxovanadium (IV) Complexes, Antimicrobial Activity, Cytotoxic Activity, Breast Cancer

\section{Introduction}

Vanadium complexes have various biological activities, for example, an insulin-like activity [1]-[2] and the de-

*Corresponding author.

How to cite this paper: Hassoon, A.A., Al-Radadi, N.S., Nawar, N. and Mostafa, M.M. (2016) New Square-Pyramidal Oxovanadium (IV) Complexes Derived from Polydentate Ligand ( $\mathrm{L}^{1}$ ). Open Journal of Inorganic Chemistry, 6, 23-65. 
crease of hyperlipidemia and hypertension. Vanadium has a decent therapeutic potential, moreover, dietary organization restrains synthetically actuated mammary carcinogenesis [3]. Likewise, it is found that concentrations of vanadium, evaluated by X-ray energy fluorescence are observed to be fundamentally higher in malignant bosom tissue contrasted with typical bosom tissue [4]. The complexes of $\mathbf{L}^{\mathbf{1}}$ are utilized in various applications like luminescent materials [5], electrocatalytical [6], photocatalytic reactions, biocatalytic activity as antitumor agents [7] and as a catalyst [8] [9]. Additionally, they have been utilized for the formation of coordination polymers and networks [9]. Metal complexes have risen as viable alternatives to organic molecules as therapeutic agents in the course of recent decades [10]-[13]. Our goal in this paper is to synthesize and characterize six $\mathrm{V}^{4+}$ complexes by (IR, UV-vis, mass and ESR), magnetic and thermal measurements. The outcomes propose that $\mathbf{L}^{\mathbf{1}}$ coordinates in different ways in all complexes through one nitrogen of triazine and nitrogen atoms of pyridine. The DFT outcomes are discussed and the biological studies of the $\mathrm{V}^{4+}$ complexes show promising affect against breast and ovarian cancer.

\section{Experimental}

\subsection{Materials and Methods}

All materials and solvents were purchased from $\mathrm{BDH}$ and Aldrich quality and used without purification. $\mathrm{VOSO}_{4} \cdot 3 \mathrm{H}_{2} \mathrm{O}$ was of Aldrich quality and used without purification. Carbon, hydrogen, nitrogen, sulphate and chloride were determined by the standard methods [14].

\subsection{Instruments}

IR spectra (400 - $4000 \mathrm{~cm}^{-1}$ ) using $\mathrm{KBr}$ discs and/or Nujolmull were recorded with a Mattson 5000 FTIR spectrophotometer. Electronic spectra were recorded using Unicam UV-visible UV2 and V-100 spectrophotometers. The magnetic measurements were carried out at room temperature $\left(25^{\circ} \mathrm{C}\right)$ using a Sherwood magnetic balance. Diamagnetic corrections were calculated using Pascal's constants [15]. The mass spectra of the complexes were recorded using a direct inlet unit (DI-50) of a Shimadzu GC/MS-QP5050A mass spectrometer at the Regional Center for Mycology and Biotechnology at Al-Azhar University. Thermogravimetric analysis (TGA) was carried out in the range $20^{\circ} \mathrm{C}-1000^{\circ} \mathrm{C}$ with a Shimadzu TGA-50 analyser at a heating rate of $15^{\circ} \mathrm{C} \mathrm{min}{ }^{-1}$ and nitrogen flow rate of $20 \mathrm{~mL} \cdot \mathrm{min}^{-1}$. A powder ESR spectrum was obtained in a $2 \mathrm{~mm}$ quartz capillary at room temperature with a Bruker EMX spectrometer working in the X-band $(9.43 \mathrm{GHz})$ with $100 \mathrm{KHz}$ modulation frequency. The results were analyzed after compensating the residual current at the corresponding condition. The electrochemical cell used as conventional three electrode type saturated calomel electrode (SCE) as a reference electrode and Pt wire and glass carbon as auxiliary and working electrode. $0.1 \mathrm{M}$ tetrabutylammonium perchlorate (TBAP) as electrolyte. A scan rate of $50 \mathrm{mV} \cdot \mathrm{s}^{-1}$ was employed.

\subsection{Synthesis of Metal Complexes}

\subsubsection{Synthesis of $\left[\mathrm{V}_{3} \mathrm{O}_{3}\left(\mathrm{~L}^{1}\right)\left(\mathrm{SO}_{4}\right)_{3}(\mathrm{EtOH})_{1 / 2}\left(\mathrm{H}_{2} \mathrm{O}\right)_{3 / 2}\right](1)$}

The complex was prepared by adding $1 \mathrm{mmol}, 0.31 \mathrm{~g}$ of 2,4,6-tri-(2-pyridyl)-1,3,5-triazine $\left(\mathbf{L}^{\mathbf{1}}\right)$; dissolved in a mixture of dist. $\mathrm{H}_{2} \mathrm{O}$ and hot EtOH (9:1) to $\mathrm{VOSO}_{4} \cdot 3 \mathrm{H}_{2} \mathrm{O}\left(2 \mathrm{mmol}, 0.44 \mathrm{~g}\right.$ ) dissolved in $100 \mathrm{ml} \mathrm{H}_{2} \mathrm{O}$. The reaction mixture was refluxed on a hot plate for 2 hrs. The complex was isolated in the $\mathrm{pH}$ range 5 - 6 . The complex was filtered off, washed successfully with EtOH and diethyl ether, respectively and finally dried in a desiccator over $\mathrm{CaCl}_{2}$. The isolated product is in color. The chemical formula of the green $\mathrm{V}$ (IV) complex, $\left[\mathrm{V}_{3} \mathrm{O}_{3}\left(\mathbf{L}^{\mathbf{1}}\right)\right.$ $\left(\mathrm{SO}_{4}\right)_{3}(\mathrm{EtOH})_{1 / 2}\left(\mathrm{H}_{2} \mathrm{O}\right)_{3 / 2}$, is Anal. Found: C, 29.6; $\mathrm{H}, 2.9 ; \mathrm{N}, 10.2 \%$. Calcd: for $\mathrm{C}_{19} \mathrm{H}_{18} \mathrm{~N}_{6} \mathrm{~S}_{3} \mathrm{O}_{17} \mathrm{~V}_{3}: \mathrm{C}, 26.8 ; \mathrm{H}$, 2.1; N, 9.9\%; m.p.; $>300^{\circ} \mathrm{C}$; Yield: $60 \%$. The powder IR $\left(\mathrm{KBr}, \mathrm{cm}^{-1}\right)$ : $3222-3447(\mathrm{OH}), 3081(\mathrm{CH})$ aromatic, 1486 - $1228(\mathrm{C}-\mathrm{N}+\mathrm{C}-\mathrm{C}), 1550,1575,1604,1651(\mathrm{C}=\mathrm{C}+\mathrm{C}=\mathrm{N})$ coordinated, $1685(\mathrm{C}=\mathrm{N}+\mathrm{C}=\mathrm{N})$ uncoordinated, 768 (C-H) deformation, 424 (V-N) py, 452 (V-N) triaz, 515 (V-O). MS (70 eV) m/z (\%): 852 (M, 1.12), 312 (5), 234 (16), 180 (64), 104 (68), 91 (16), 77 (45), 67 (41), 51(100).

\subsubsection{Synthesis of $\left[\mathrm{VO}\left(\mathrm{L}^{1}\right)(2,4-\mathrm{Pentadionate})\right] \cdot \mathrm{Cl} \cdot 4 \mathrm{HCl}(2)$}

The complex was prepared by adding anEtOH solution of $\mathbf{L}^{1}$; 1 mmol, $0.31 \mathrm{~g}$ ), and $\mathrm{V}$ (IV) oxide bis (2,4-pentanedionate) (1 mmol, $0.27 \mathrm{~g}$ ) dissolved in hot EtOH. The reaction mixtures were refluxed on a hot plate for 2 hrs. The $\mathrm{pH}$ of the solution was 5 - 6 . On adding few drops of conc. $\mathrm{HCl}$ the complex was precipitated in the $\mathrm{pH}$ 
range 2 - 3. The isolated product is brick red in color. Yield $80 \%$; m.p. $>300^{\circ} \mathrm{C}$. IR $\left(\mathrm{KBr}, \mathrm{cm}^{-1}\right)$ : $3433-3478$ $(\mathrm{OH}), 3077(\mathrm{CH})$ aromatic, 1485-1223 (C-N+C-C), 1555, $1576(\mathrm{C}=\mathrm{C}+\mathrm{C}=\mathrm{N})$ coordinated, $1671(\mathrm{C}=\mathrm{N}+\mathrm{C}=\mathrm{N})$ uncoordinated, 787 (C-H) deformation, 424 (V-N)py, 442 (V-N)triaz, 550 (V-O). MS (70 eV) m/z (\%): 659 (M, 1.2), 517 (68), 447 (18), 432 (19), 392 (70), 312 (100), 104 (45), 78 (26), (64) (25), (52) (26). Anal. Calcd for $\mathrm{C}_{23} \mathrm{H}_{23} \mathrm{~N}_{6} \mathrm{O}_{3} \mathrm{Cl}_{5} \mathrm{~V}$ (659.7): C: 41.9; H: 3.5; Cl: 26.9\%. Found: C: 42.6; H: 2.9; Cl: 26.4\%.

\subsubsection{Synthesis of $\left[\mathrm{V}_{2} \mathrm{O}_{2}\left(\mathrm{~L}^{1}\right)\left(\mathrm{SO}_{4}\right)_{2}(\mathrm{EtOH})_{5 / 2}\right](3)$ and $\left[\mathrm{V}_{2} \mathrm{O}_{2}\left(\mathrm{~L}^{1}\right)\left(\mathrm{SO}_{4}\right)_{2}(\mathrm{EtOH})_{3 / 2}\left(\mathrm{H}_{2} \mathrm{O}\right)_{1 / 2}\right]$ (4)}

The complex was synthesized by adding $1 \mathrm{mmol},(0.31 \mathrm{~g})$ of $\mathbf{L}^{1}$ dissolved in dist. water and hot EtOH with ratio (1:9) to $\mathrm{VOSO}_{4}$ solution ( $2 \mathrm{mmol}, 0.44 \mathrm{~g}$ ) dissolved in $100 \mathrm{ml}$ redistilled water $\mathrm{H}_{2} \mathrm{O}$. The reaction mixture was refluxed on a hot plate for $2 \mathrm{~h}$. The complex was isolated in the $\mathrm{pH}$ range $5-6$. Yield $50 \%$; green powder; m.p. $>300^{\circ} \mathrm{C}$. IR $\left(\mathrm{KBr}, \mathrm{cm}^{-1}\right): 3403-3445(\mathrm{OH}), 3078(\mathrm{CH})$ aromatic, $1478-1262(\mathrm{C}-\mathrm{N}+\mathrm{C}-\mathrm{C}), 1603,1575$, 1562, $1542(\mathrm{C}=\mathrm{C}+\mathrm{C}=\mathrm{N})$ coordinated, 1686, $1653(\mathrm{C}=\mathrm{N}+\mathrm{C}=\mathrm{N})$ uncoordinated, $767(\mathrm{C}-\mathrm{H})$ deformation, 425, 445 (V-N) pyr, 474, 489 (V-N) triaz, 547, 577 (V-O). MS (70 eV) m/z (\%): 753.6 (M, 8.6), 682 (13), 604 (11), 417 (10), 363 (8), 315 (6), 234 (20), 185 (14), 155 (13), 104 (14), 91 (9), 78 (35), 64 (17), 53 (100). Anal. Calcd for $\mathrm{C}_{23} \mathrm{H}_{27} \mathrm{~N}_{6} \mathrm{O}_{25 / 2} \mathrm{~S}_{2} \mathrm{~V}_{2}$ (753.5): C: 36.7; H: 3.6; N: 11.1\%. Found: C: 37.7; H: 2.6; N: $10.2 \%$ and $\mu_{\text {eff }}(3.01 \mathrm{BM})$. $\left[\mathrm{V}_{2} \mathrm{O}_{2}\left(\mathbf{L}^{1}\right)\left(\mathrm{SO}_{4}\right)_{2}(\mathrm{EtOH})_{3 / 2}\left(\mathrm{H}_{2} \mathrm{O}\right)_{1 / 2}\right]$ (4) was obtained from the filtrate after cooling. Yield 50\%; green powder; m.p. $>300^{\circ} \mathrm{C}$. IR $\left(\mathrm{KBr}, \mathrm{cm}^{-1}\right)$ : $3269-3449(\mathrm{OH}), 3042(\mathrm{CH})$ aromatic, $1401-1249(\mathrm{C}-\mathrm{N}+\mathrm{C}-\mathrm{C}), 1653,1588$ $(\mathrm{C}=\mathrm{C}+\mathrm{C}=\mathrm{N})$ coordinated, $1683(\mathrm{C}=\mathrm{N}+\mathrm{C}=\mathrm{N})$ uncoordinated, $767(\mathrm{C}-\mathrm{H})$ deformation, $427(\mathrm{~V}-\mathrm{N})$ pyr, $453(\mathrm{~V}-\mathrm{N})$ triaz, 514 (V-O). MS (70 eV) m/z (\%): 714 (M-2H, 7.9), 622 (13), 311 (6), 232 (8), 183 (29), 155 (18), 104 (71), 91 (93), 77 (81), 51 (100). Anal. Calcd for $\mathrm{C}_{21} \mathrm{H}_{22} \mathrm{~N}_{6} \mathrm{O}_{12} \mathrm{~S}_{2} \mathrm{~V}_{2}$ (716.44): C: 35.2; H: 3.1; N: 11.7 \%. Found: C: 34.8; H: 3; N: $11.2 \%$ and $\mu_{\text {eff }}(2.66 \mathrm{BM})$.

\subsubsection{Synthesis of $\left[\mathrm{VO}\left(\mathrm{L}^{1}\right) \mathrm{SO}_{4}\left(\mathrm{H}_{2} \mathrm{O}\right)_{3 / 2}\right] \cdot 2.5 \mathrm{H}_{2} \mathrm{O}(5)$ and $\left[\mathrm{V}_{2} \mathrm{O}_{2}\left(\mathrm{~L}^{1}\right)\left(\mathrm{SO}_{4}\right)_{2}\left(\mathrm{H}_{2} \mathrm{O}\right)\right] \cdot \mathrm{H}_{2} \mathrm{O}(6)$}

$\left[\mathrm{VO}\left(\mathbf{L}^{1}\right) \mathrm{SO}_{4}\left(\mathrm{H}_{2} \mathrm{O}\right)_{3 / 2}\right] \cdot 2.5 \mathrm{H}_{2} \mathrm{O}(5)$ and $\left[\mathrm{V}_{2} \mathrm{O}_{2}\left(\mathbf{L}^{\mathbf{1}}\right)\left(\mathrm{SO}_{4}\right)_{2}\left(\mathrm{H}_{2} \mathrm{O}\right)\right] \cdot \mathrm{H}_{2} \mathrm{O}(6)$ were synthesized with different molar ratios 1:1 and 2:1 (M:L), respectively. A hot EtOH solution of $\mathbf{L}^{1}(0.312 \mathrm{~g} ; 1.0 \mathrm{mmol})$ was added to $\mathrm{VOSO}_{4} \cdot 3 \mathrm{H}_{2} \mathrm{O}$ dissolved in hot EtOH (0.22 g, $0.44 \mathrm{~g} ; 1.0 \mathrm{mmol}$ and $2.0 \mathrm{mmol}$ for 1:1 and 2:1, respectively). The reaction mixtures were refluxed on a hot plate for $2 \mathrm{~h}$. All complexes were filtered off, washed several times with hot EtOH, dried in an oven at $120^{\circ} \mathrm{C}$ for $0.5 \mathrm{~h}$ and finally kept in a desiccator over $\mathrm{CaCl}_{2}$. $\left[\mathrm{VO}\left(\mathbf{L}^{1}\right) \mathrm{SO}_{4}\left(\mathrm{H}_{2} \mathrm{O}\right)_{3 / 2}\right] \cdot 2.5 \mathrm{H}_{2} \mathrm{O}(5)$ : yield 58\%; color brown powder; m.p. $>300^{\circ} \mathrm{C}$. IR $\left(\mathrm{KBr}, \mathrm{cm}^{-1}\right)$ : 3387(OH), $3069(\mathrm{CH})$ aromatic, $1489-1215$ $(\mathrm{C}-\mathrm{N}+\mathrm{C}-\mathrm{C}), 1642(\mathrm{C}=\mathrm{C}+\mathrm{C}=\mathrm{N})$ coordinated, $1548(\mathrm{C}=\mathrm{N}+\mathrm{C}=\mathrm{N})$ uncoordinated, $775(\mathrm{C}-\mathrm{H})$ deformation, 434 (V-N)pyr, 486 (V-N)triaz, 528 (V-O). MS (70 eV) m/z (\%): 547.6 (M, 4.6), 461 (1.83), 360 (5.7), 312 (62), 156 (7), 104 (73), 78 (53), 52 (100). Anal. Calcd for $\mathrm{C}_{18} \mathrm{H}_{20} \mathrm{~N}_{6} \mathrm{SO}_{9} \mathrm{~V}$ (547.39): C: 39.5; H: 3.7; N: 15.35; $\mathrm{SO}_{4}: 17.6 \%$ \% Found: C: 39.1; $\mathrm{H}$ : 3.1; N: 15.02; $\mathrm{SO}_{4}: 17.8 \%$ and $\mu_{\text {eff }}(2.7 \mathrm{BM}) .\left[\mathrm{V}_{2} \mathrm{O}_{2}\left(\mathbf{L}^{1}\right)\left(\mathrm{SO}_{4}\right)_{2}\left(\mathrm{H}_{2} \mathrm{O}\right)\right] \cdot \mathrm{H}_{2} \mathrm{O}$ (6): yield 51\%; color brown powder; m.p. $>300^{\circ} \mathrm{C}$. IR $\left(\mathrm{KBr}, \mathrm{cm}^{-1}\right)$ : 3384(OH), $3071(\mathrm{CH})$ aromatic, $1489-1216(\mathrm{C}-\mathrm{N}+\mathrm{C}-\mathrm{C})$, $1642(\mathrm{C}=\mathrm{N}+\mathrm{C}=\mathrm{N})$ coordinated, $1548(\mathrm{C}=\mathrm{N}+\mathrm{C}=\mathrm{N})$ uncoordinated, $777(\mathrm{C}-\mathrm{H})$ deformation, 441 (V-N)pyr, 485 (V-N)triaz, 606 (V-O). MS (70 eV) m/z (\%): 672.35 (-2M, 3), 651 (4), 414 (5), 360 (4), 312 (97), 156 (5), 130 (6), 105 (100), 78 (32), 52 (28). Anal. Calcd. for $\mathrm{C}_{18} \mathrm{H}_{16} \mathrm{~N}_{6} \mathrm{~S}_{2} \mathrm{O}_{12} \mathrm{~V}_{2}$ (674.36): C: 32.1; H: 2.4; N: 12.5; $\mathrm{SO}_{4}$ : 28.5\%. Found: C: 32.5; H: 2.8; N: 12.4; $\mathrm{SO}_{4}: 29.3 \%$ and $\mu_{\text {eff }}(2.8 \mathrm{BM})$.

\subsection{Biological Activity}

\subsubsection{In Vitro Anticancer Activity}

The antitumor assays were performed utilizing the accompanying two cell lines: MCF-7 (Michigan Cancer Foundation-7) and Epitheliod carcinoma cervix cancer (Hela). The cell line of MCF-7 was acquired from the American Type Culture Collection (ATCC, Rockville, MD). The cells were developed onRPMI-1640 medium supplemented with $10 \%$ inactivated fetal calf serum and $50 \mathrm{mg} / \mathrm{ml}$ gentamycin. The cells were kept up at $37^{\circ} \mathrm{C}$ in humidified atmosphere with $5 \% \mathrm{CO}_{2}$ and were sub-refined a few times each week.

The antitumor activity was assessed on carcinoma cell lines at the Regional center for Mycology and Biotechnology at Al-Azhar University, Egypt. Quickly, the cell lines were developed as monolayers in growth medium supplemented with $10 \%$ inactivated fetal calf serum and $50 \mathrm{mg} / \mathrm{ml}$ gentamycin. The monolayers of 10.000 cells followed at the bottom of the wells in a 96-well microtiter plate (Falcon. NJ. USA) brooded for $24 \mathrm{~h}$ at $37^{\circ} \mathrm{C}$ in a humidified incubator with $5 \% \mathrm{CO}_{2}$. The monolayers were then washed with sterile phosphate buffered saline (0.01 M pH 7.2) and at the same time the cells were treated with $100 \mathrm{~mL}$ from various dilutions of tested 
compound in fresh maintenance medium and brooded at $37^{\circ} \mathrm{C}$. A control of untreated cells was made without the tried compound. Three wells were utilized for every concentration of the test sample. The observation under the inverted microscope was made each $24 \mathrm{~h}$. The staining so as to survive quantity cells was controlled the cells with precious stone violet took after by cell lysing utilizing 33\% glacial acetic acid and read the absorbance at $590 \mathrm{~nm}$ utilizing ELISA reader after well mixing. The absorbance values from untreated cells were considered as $100 \%$ expansion and the rate of feasibility was ascertained as [1-(ODt/ODc) $\times 100 \%$ where ODt is the mean optical density of wells treated with the tried compounds and ODc is the mean optical density of untreated cells [16]-[18].

The cell line of Epitheliod carcinoma cervix cancer (Hela) was gotten from ATCC via Holding company for biological products and vaccines (VACSERA), Cairo, Egypt. 5-fluorouracil was utilized as a standard anticancer drug for comparison. The cell line was utilized to focus the inhibitory impacts of compounds on cell development utilizing the MTT assay. The colorimetric assay is basically depending on the transformation of the yellow tetrazolium bromide (MTT) to a purple form azan derivative by mitochondrial succinate dehydrogenase in various cells. Hela cells were cultured in RPMI-1640 medium with 10\% fetal bovine serum. Antibiotics added were 100 units $/ \mathrm{ml}$ penicillin and $100 \mu \mathrm{g} / \mathrm{ml}$ streptomycin at $37^{\circ} \mathrm{C}$ in a $5 \% \mathrm{CO}_{2}$ incubator. The cell line was seeds in a 96-well plate at a density of $1.0 \times 10^{4}$ cells/well at $37^{\circ} \mathrm{C}$ for $48 \mathrm{~h}$ under $5 \% \mathrm{CO}_{2}$. After brooding the cells were tested with different concentration of compounds and incubated for $24 \mathrm{~h}$. After $24 \mathrm{~h}$ of drug treatment, $20 \mu \mathrm{l}$ of MTT solution at $5 \mathrm{mg} / \mathrm{ml}$ was added and incubated for $4 \mathrm{~h}$. DMSO in volume of $100 \mu \mathrm{L}$ is added into each well to dissolve the purple formazan formed. The colorimetric assay is measured and recorded at absorbance of 570 $\mathrm{nm}$ utilizing a plate reader (EXL 800). The relative cell viability in percentage was computed as (A570 of treated samples/A570 of untreated sample) X 100 [16] [19]-[20].

\subsubsection{Antibacterial Activities}

The in vitro assessment of antibacterial activity was researched against three bacterial strains, Gram-positive (Staphylococcus aureus), Gram-negative (Escherichia coli) bacterial and Candida Albicans. The bacterial species were developed in nutrient broth at $37^{\circ} \mathrm{C}$ for 24 hrs [21].

Chemical compounds were individually tried against a panel of Gram-positive (Staphylococcus aureus), Gram-negative (Escherichia coli) bacteria and Candida albicans. Every of the compounds was dissolved in DMSO and solution of the concentration $1 \mathrm{mg} / \mathrm{ml}$ were prepared separately paper discs of whatman filter paper were prepared with standard size $(5 \mathrm{~cm})$ were cut and sterilized in an autoclave. The paper discs soaked in the desired concentration of the complex solution were places aseptically in the Petri dishes containing nutrient agar media (peptone $5 \mathrm{~g}+$ agar $20 \mathrm{~g}+$ beef extract $3 \mathrm{~g}$ ) seeded with Staphylococcus aureus, E. coli and Candida albicans. The Petri dishes were incubated at $36^{\circ} \mathrm{C}$ and the inhibition zones were recorded after 24 hrs of incubation. Every treatment was replicated three times. The antibacterial activity of a common standard Antifungal Colitrimazole and antibiotic ampicillin was also recorded utilizing the same procedure as above at the same solvents and concentration.

\subsection{Solution Studies}

Stock solutions $\left(1 \times 10^{-2} \mathrm{M}\right)$ of $\mathbf{L}^{\mathbf{1}}$ and $\mathrm{VOSO}_{4} \cdot 3 \mathrm{H}_{2} \mathrm{O}$ were prepared by dissolving the calculated accurate weights of $\mathbf{L}^{1}$ and $\mathrm{VOSO}_{4} \cdot 3 \mathrm{H}_{2} \mathrm{O}$ in absolute EtOH and dist. $\mathrm{H}_{2} \mathrm{O}$, respectively then completed to the mark (50 $\mathrm{ml}$ ). In continuous variation (CV) study, a series of $10 \mathrm{ml}$ solutions was prepared by mixing solutions of $\mathrm{V}^{4+}$ and $\mathbf{L}^{1}$ solutions in different ratios keeping the total molar concentration constant as $6 \times 10^{-3} \mathrm{M}$ and the absorbance at $604 \mathrm{~nm}$ was recorded. For molar ratio method (MR), series of $10 \mathrm{ml}$ solutions was prepared in which the $\mathrm{V}^{4+}$ ion concentration was kept constant at $2.5 \times 10^{-3} \mathrm{M}$ while that of $\mathbf{L}^{\mathbf{1}}$ was regularly varied. The absorption spectra were recorded and the absorbance at $604 \mathrm{~nm}$.

\section{Results and Discussion}

\subsection{Physical Properties and Elemental Analyses}

$\mathbf{L}^{1}$ coordinates to the $\mathrm{V}^{4+}$ ions in different styles like mononuclear (1:1), binuclear (2:1) and tri-nuclear (3:1) $(\mathrm{M}: \mathrm{L})$ in bidentate and tridentate manner. The metal complexes are non-hygroscopic (stable at room temperature) and are in the form of amorphous solids, except $\left[\mathrm{VO}\left(\mathbf{L}^{1}\right) \mathrm{SO}_{4}\left(\mathrm{H}_{2} \mathrm{O}\right)_{3 / 2}\right] \cdot 2.5 \mathrm{H}_{2} \mathrm{O}$ and $\left[\mathrm{V}_{2} \mathrm{O}_{2}\left(\mathbf{L}^{1}\right)\left(\mathrm{SO}_{4}\right)_{2}\left(\mathrm{H}_{2} \mathrm{O}\right)\right] \cdot \mathrm{H}_{2} \mathrm{O}$, 
but unfortunately crystals suitable for X-ray measurements were not available. Complex (2) is soluble in water and common organic solvents as DMF, DMSO and water. The structures of the complexes are established by elemental analyses and confirmed by weight loss determination. The values of molar conductivity of all complexes indicate that $\left[\mathrm{V}_{3} \mathrm{O}_{3}\left(\mathbf{L}^{1}\right)\left(\mathrm{SO}_{4}\right)_{3}(\mathrm{EtOH})_{1 / 2}\left(\mathrm{H}_{2} \mathrm{O}\right)_{3 / 2}\right],\left[\mathrm{V}_{2} \mathrm{O}_{2}\left(\mathbf{L}^{1}\right)\left(\mathrm{SO}_{4}\right)_{2}(\mathrm{EtOH})_{5 / 2}\right],\left[\mathrm{V}_{2} \mathrm{O}_{2}\left(\mathbf{L}^{1}\right)\left(\mathrm{SO}_{4}\right)_{2}(\mathrm{EtOH})_{3 / 2}\right.$ $\left.\left(\mathrm{H}_{2} \mathrm{O}\right)_{1 / 2}\right]$, $\left[\mathrm{VO}\left(\mathbf{L}^{1}\right) \mathrm{SO}_{4}\left(\mathrm{H}_{2} \mathrm{O}\right)_{3 / 2}\right] \cdot 2.5 \mathrm{H}_{2} \mathrm{O}$ and $\left[\mathrm{V}_{2} \mathrm{O}_{2}\left(\mathbf{L}^{1}\right)\left(\mathrm{SO}_{4}\right)_{2}\left(\mathrm{H}_{2} \mathrm{O}\right)\right] \cdot \mathrm{H}_{2} \mathrm{O}$ are non-electrolytic nature, while [VO $\left(\mathbf{L}^{1}\right)(2,4$-pentadionate)] $\mathrm{Cl} \cdot 4 \mathrm{HCl}$ has electrolytic nature [22].

\subsection{Infrared Spectra}

The comparative IR spectra of the ligand and oxovanadium (IV) complexes indicate about the binding behavior of the ligand with metal ion. So, in comparing the IR of the $\mathbf{L}^{1}$ (Figure S1) with its complexes (Figure S2-S6), we find that the IR spectrum of the $\left[\mathrm{V}_{3} \mathrm{O}_{3}\left(\mathbf{L}^{1}\right)\left(\mathrm{SO}_{4}\right)_{3}(\mathrm{EtOH})_{1 / 2}\left(\mathrm{H}_{2} \mathrm{O}\right)_{3 / 2}\right]$ (Figure 1) shows four bands at 1550, 1575,1601 and $1651 \mathrm{~cm}^{-1}$ which are shifted to lower wave numbers and are attributed to the coordinated $v(\mathrm{C}=\mathrm{N}$ $+C=C$ ) [23] [24], which indicate that $\mathbf{L}^{1}$ coordinates as bidentate via all the active group in pyridine and triazine rings with three vanadium atoms. The square pyramidal geometry around $\mathrm{V}^{4+}$ is completed by water, EtOH and sulphate which have characteristics bands appeared in the spectrum. The spectrum also shows broad bands in the $3222-3447 \mathrm{~cm}^{-1}$ region together with a band at $1604 \mathrm{~cm}^{-1}$ region assigned to $v(\mathrm{OH})$ and $\partial(\mathrm{OH})$ vibrations of $\mathrm{H}_{2} \mathrm{O}$ molecule, respectively. Existence of strong band at $976 \mathrm{~cm}^{-1}$ is strong evidence for the coordination of vanadium ion with $\mathbf{L}^{1}$ as it is characterized for $\mathrm{V}=\mathrm{O}$ vibration in $\mathrm{VO}^{2+}$ [25]. In addition, new bands are observed at 424 and $452 \mathrm{~cm}^{-1}$ which are assigned to V-N bonds of pyridine and triazine, respectively, and at 515 and 592 $\mathrm{cm}^{-1}$ which are assigned to V-O bond [26]. Also, new bands at 424, 625, 978, $1033 \mathrm{~cm}^{-1}$ are assigned to coordinated $\mathrm{SO}_{4}^{2-}$ group and the position of these bands indicates the participation of the $\mathrm{SO}_{4}^{2-}$ in a unidentatemanner as a result, the complex is nonelectrolyte.

The IR spectrum of the $\left[\mathrm{VO}\left(\mathbf{L}^{\mathbf{1}}\right)(2,4\right.$-pentadionate) $\mathrm{Cl} \cdot 4 \mathrm{HCl}$ (Figure S2) estimates bands, which are shifted to lower wave numbers and are observed at 1634 and $1576 \mathrm{~cm}^{-1}$ and are referred to the bands of the coordinated $v(\mathrm{C}=\mathrm{N}+\mathrm{C}=\mathrm{C})$ for triazine and pyridine, respectively indicating the involvement of $\mathrm{C}=\mathrm{N}$ in coordination to the metal ion [23] [24] as well as new bands at 424 and $442 \mathrm{~cm}^{-1}$ which are assigned to $\mathrm{V}-\mathrm{N}$ bonds of pyridine and triazine, respectively, and a band at $550 \mathrm{~cm}^{-1}$ which is assigned to $\mathrm{V}-\mathrm{O}$ vibration [26].

IR spectrum of $\left[\mathrm{V}_{2} \mathrm{O}_{2}\left(\mathbf{L}^{1}\right)\left(\mathrm{SO}_{4}\right)_{2}(\mathrm{EtOH})_{5 / 2}\right]$ (Figure S3) shows bands at 1603, 1575, 1562 and $1542 \mathrm{~cm}^{-1}$ are referred to the bands of the coordinated $v(\mathrm{C}=\mathrm{N}+\mathrm{C}=\mathrm{C})$ [23] [24], in addition, a broad band in the $3403-3445$ $\mathrm{cm}^{-1}$ region together with a band at $1603 \mathrm{~cm}^{-1}$ region assigns to $v(\mathrm{OH})$ and $\partial(\mathrm{OH})$ vibrations of coordinated $\mathrm{EtOH}$ molecules, respectively and coincides with the results of the thermal analyses which suggest that EtOH molecules reside inside the coordination sphere. Moreover, the band in the $3031-3078 \mathrm{~cm}^{-1}$ region is assigned to the aromatic $v(\mathrm{C}-\mathrm{H})$ vibration of $\mathbf{L}^{\mathbf{1}}$ in the complex. The bands observed in the $1478-1262 \mathrm{~cm}^{-1}$ region are assigned to (C-N+C-C) while the band at $767 \mathrm{~cm}^{-1}$ is assigned to the aromatic $\mathrm{C}-\mathrm{H}$ deformation vibration. A vanadyl complex shows a band at $978 \mathrm{~cm}^{-1}$ which may be attributed to the $v(\mathrm{~V}=\mathrm{O})$ vibration of $\mathrm{VO}^{2+}$ [25]. New bands are

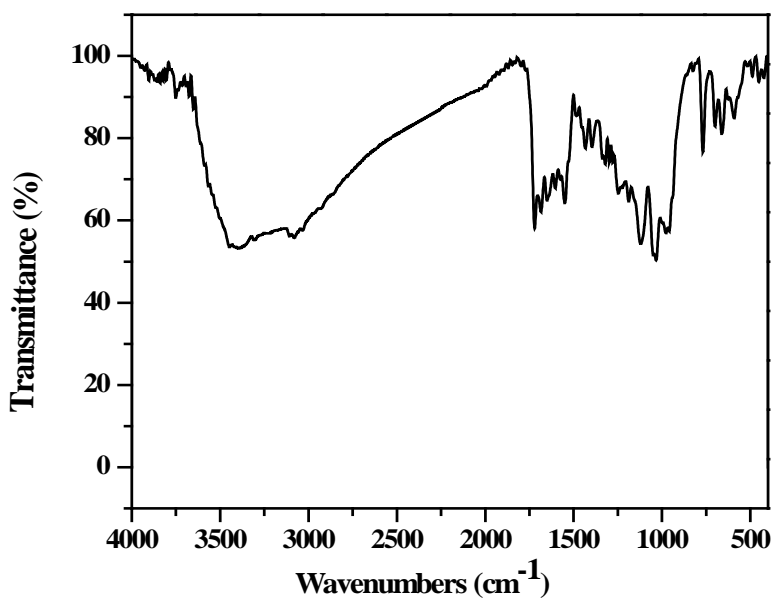

Figure 1. IR spectrum of the $\left[\mathrm{V}_{3} \mathrm{O}_{3}\left(\mathrm{~L}^{1}\right)\left(\mathrm{SO}_{4}\right)_{3}(\mathrm{EtOH})_{1 / 2}\right.$ $\left(\mathrm{H}_{2} \mathrm{O}\right)_{3 / 2}$ ] complex. 
observed at 425, 445 (V-N)pyr, 474, 489 (V-N) triaz, 547, $577(\mathrm{~V}-\mathrm{O}) \mathrm{cm}^{-1}$ [26]. Also, new bands are observed at 425, 629, 956 and $1032 \mathrm{~cm}^{-1}$ which are assigned to coordinated $\mathrm{SO}_{4}^{2-}$ group and the position of bands are assigned to that $\mathrm{SO}_{4}^{2-}$ group bonded as unidentate ligand which is in agreement with the conductivity measurements.

IR spectrum of the $\left[\mathrm{V}_{2} \mathrm{O}_{2}\left(\mathbf{L}^{1}\right)\left(\mathrm{SO}_{4}\right)_{2}(\mathrm{EtOH})_{3 / 2}\left(\mathrm{H}_{2} \mathrm{O}\right)_{1 / 2}\right]$ (Figure S4) shows bands at 1653 and $1588 \mathrm{~cm}^{-1}$ arecharacterized to coordinated $\mathrm{v}(\mathrm{C}=\mathrm{N}+\mathrm{C}=\mathrm{C})$ [23] [24]. Presence of $\mathrm{H}_{2} \mathrm{O}$ and EtOH is proved by existence ofa broad band in the $3305-3449 \mathrm{~cm}^{-1}$ region together with a band at $1610 \mathrm{~cm}^{-1}$ region assigned to $v(\mathrm{OH})$ and $\partial(\mathrm{OH})$ vibrations of $\mathrm{H}_{2} \mathrm{O}$ molecule, respectively. Peaks revealing the presence of $\mathbf{L}^{\mathbf{1}}$ in the complex centered at $3042 \mathrm{~cm}^{-1}$ (aromatic C-H stretching vibration). New bands are observed at 427 (V-N)py, 453 (V-N)triaz, 514 (V-O) $\mathrm{cm}^{-1}$ [26]. Additionally, thevanadyl complex shows a strong band at $984 \mathrm{~cm}^{-1}$ which may be attributed to the $v(\mathrm{~V}=\mathrm{O})$ vibration of $\mathrm{VO}^{2+}$ [25]. Also, the bands at 427,653, 978, $1033 \mathrm{~cm}^{-1}$ are assigned to coordinated $\mathrm{SO}_{4}^{2-}$ group and the position of bands assigned to that $\mathrm{SO}_{4}^{2-}$ group bonded as unidentate ligand.

The IR spectrum of $\left[\mathrm{VO}\left(\mathbf{L}^{1}\right) \mathrm{SO}_{4}\left(\mathrm{H}_{2} \mathrm{O}\right)_{3 / 2}\right] \cdot 2.5 \mathrm{H}_{2} \mathrm{O}$ (Figure S5) shows bands at 1642 and $1548 \mathrm{~cm}^{-1}$ are referred to the bands of the coordinated $\mathrm{v}(\mathrm{C}=\mathrm{N}+\mathrm{C}=\mathrm{C})$ and the uncoordinated $(\mathrm{C}=\mathrm{N}+\mathrm{C}=\mathrm{C})$ band, respectively [23] [24]. Appearance of a broad band in the $3387 \mathrm{~cm}^{-1}$ region together with a band at $1621 \mathrm{~cm}^{-1}$ region assigned to $v(\mathrm{OH})$ and $\partial(\mathrm{OH})$ vibrations of $\mathrm{H}_{2} \mathrm{O}$ molecule, respectively, which suggest existence of $\mathrm{H}_{2} \mathrm{O}$ molecules inside and outside the coordination sphere. The $\mathrm{H}_{2} \mathrm{O}$ molecules inside the sphere is bonded with nitrogen atom by hydrogen bond so it proves the high shift of the band at $3387 \mathrm{~cm}^{-1}$ and the remain molecules are solvation outside the sphere. The results of thermal analyses confirmed this observation. New bands are observed at 434 and 486 $\mathrm{cm}^{-1}$ assigned to $\mathrm{V}-\mathrm{N}$ bonds of pyridine and triazine, respectively. The band at $528 \mathrm{~cm}^{-1}$ assigned to V-O vibration [26]. The oxovanadium complex shows a strong band at $971 \mathrm{~cm}^{-1}$ attributed to the high $\pi$-band order of vanadium to oxygen link of $\mathrm{VO}^{2+}$ [25]. The bands are observed at 434, 613, 971, $1032 \mathrm{~cm}^{-1}$ are assigned to the coordinated $\mathrm{SO}_{4}^{2-}$ group and the position of bands assigned to that $\mathrm{SO}_{4}^{2-}$ group bonded inunidentatemanner. The conductivity measurements supported this observation where the complex is nonelectrolyte.

The IR spectrum of $\left[\mathrm{V}_{2} \mathrm{O}_{2}\left(\mathbf{L}^{1}\right)\left(\mathrm{SO}_{4}\right)_{2}\left(\mathrm{H}_{2} \mathrm{O}\right)\right] \cdot \mathrm{H}_{2} \mathrm{O}$ (Figure S6) shows two bands at 1642 and $1548 \mathrm{~cm}^{-1}$ assigned to the coordinated $(\mathrm{C}=\mathrm{N}+\mathrm{C}=\mathrm{C})$ [23] [24]. Also, it shows a broad band at $3384 \mathrm{~cm}^{-1}$ together with a band at $1619 \mathrm{~cm}^{-1}$ assigned to $v(\mathrm{OH})$ and $\partial(\mathrm{OH})$ vibrations of $\mathrm{H}_{2} \mathrm{O}$ molecule, respectively which present inside and outside the coordination sphere. Moreover, the band at $3071 \mathrm{~cm}^{-1}$ is assigned to the aromatic $v(\mathrm{C}-\mathrm{H})$ vibrations of $\mathbf{L}^{1}$. The bands observed in the $1489-1216 \mathrm{~cm}^{-1}$ region are assigned to $(\mathrm{C}-\mathrm{N}+\mathrm{C}-\mathrm{C}$ ) while the band at 777 $\mathrm{cm}^{-1}$ region is attributed to the aromatic C-H deformation vibrations. New bands are observed at 441 and 485 $\mathrm{cm}^{-1}$ which, are assigned to V-N bonds of pyridine and triazine, respectively, and at $606 \mathrm{~cm}^{-1}$ which, is assigned to $\mathrm{V}-\mathrm{O}$ bond [26]. Appearance of strong band at $976 \mathrm{~cm}^{-1}$ is characterized for $\mathrm{V}=\mathrm{O}$ vibration in $\mathrm{VO}^{2+}$ [25]. New bands appear at 441, 606, 971, $1033 \mathrm{~cm}^{-1}$ are assigned to coordinated $\mathrm{SO}_{4}^{2-}$ group and the position of bands assigned to that $\mathrm{SO}_{4}^{2-}$ group bonded as unidentate ligand and it matches with the conductivity measurement as the complex is nonelectrolyte.

\subsection{Mass Spectra}

Mass spectra of the complexes have molecular ion peaks that are in agreement with their formulae. As we observed in all the complexes, there are two pathways. Depending on the thermodynamic basics, the pathway must be till the thermodynamically butadiene radical [27].

The mass spectrum of $\left[\mathrm{V}_{3} \mathrm{O}_{3}\left(\mathbf{L}^{1}\right)\left(\mathrm{SO}_{4}\right)_{3}(\mathrm{EtOH})_{1 / 2}\left(\mathrm{H}_{2} \mathrm{O}\right)_{3 / 2}\right]$, shows a fragmentation pattern corresponding to the successive degradation of the complex, shows the molecular ion peak $[\mathrm{m} / \mathrm{z}]$ at 852.3 with abundance $1.47 \%$ and coincides with the theoretical value (851.4) as shown in Figure 2. This suggests that the proposed structure for the complex is correct and has the chemical formula; $\mathrm{C}_{19} \mathrm{H}_{18} \mathrm{~N}_{6} \mathrm{~S}_{3} \mathrm{O}_{17} \mathrm{~V}_{3}$. The fragmentation pattern of the $\mathrm{V}^{4+}$ complex (1:3) is shown in Scheme 1. The mass spectrum of $\left[\mathrm{VO}\left(\mathbf{L}^{1}\right)(2,4\right.$-pentadionate)] $\mathrm{Cl} \cdot 4 \mathrm{HCl}$, shows the molecular ion peak $[\mathrm{m} / \mathrm{z}]$ at 659.2 with abundance $1.16 \%$ and coincides with the theoretical value (659.7) as shown in (Figure S7). The fragmentation pattern of the complex is shown in (Figure S8). This suggests that the proposed structure for the complex is correct and has the chemical formula, $\mathrm{C}_{23} \mathrm{H}_{22} \mathrm{~N}_{6} \mathrm{O}_{3} \mathrm{Cl}{ }_{5} \mathrm{~V}$. The mass spectrum of $\left[\mathrm{V}_{2} \mathrm{O}_{2}\left(\mathbf{L}^{1}\right)\left(\mathrm{SO}_{4}\right)_{2}(\mathrm{EtOH})_{5 / 2}\right]$, shows the molecular ion peak $[\mathrm{m} / \mathrm{z}]$ at 753.6 with abundance $8.6 \%$ and coincides with the theoretical value (753.501) as shown in (Figure S9). The fragmentation pattern of the complex is shown in (Figure S10). This suggests that the proposed structure for the complex is correct and has the chemical formula, $\mathrm{C}_{23} \mathrm{H}_{27} \mathrm{~N}_{6} \mathrm{O}_{25 / 2} \mathrm{~S}_{2} \mathrm{~V}_{2}$. The mass spectrum of $\left[\mathrm{V}_{2} \mathrm{O}_{2}\left(\mathbf{L}^{1}\right)\left(\mathrm{SO}_{4}\right)_{2}(\mathrm{EtOH})_{3 / 2}\left(\mathrm{H}_{2} \mathrm{O}\right)_{1 / 2}\right]$, shows the molecular ion peak $[\mathrm{m} / \mathrm{z}]$ at 714 with abundance $7.9 \%$ and coincides with the theoretical value $(716.44)$ as 


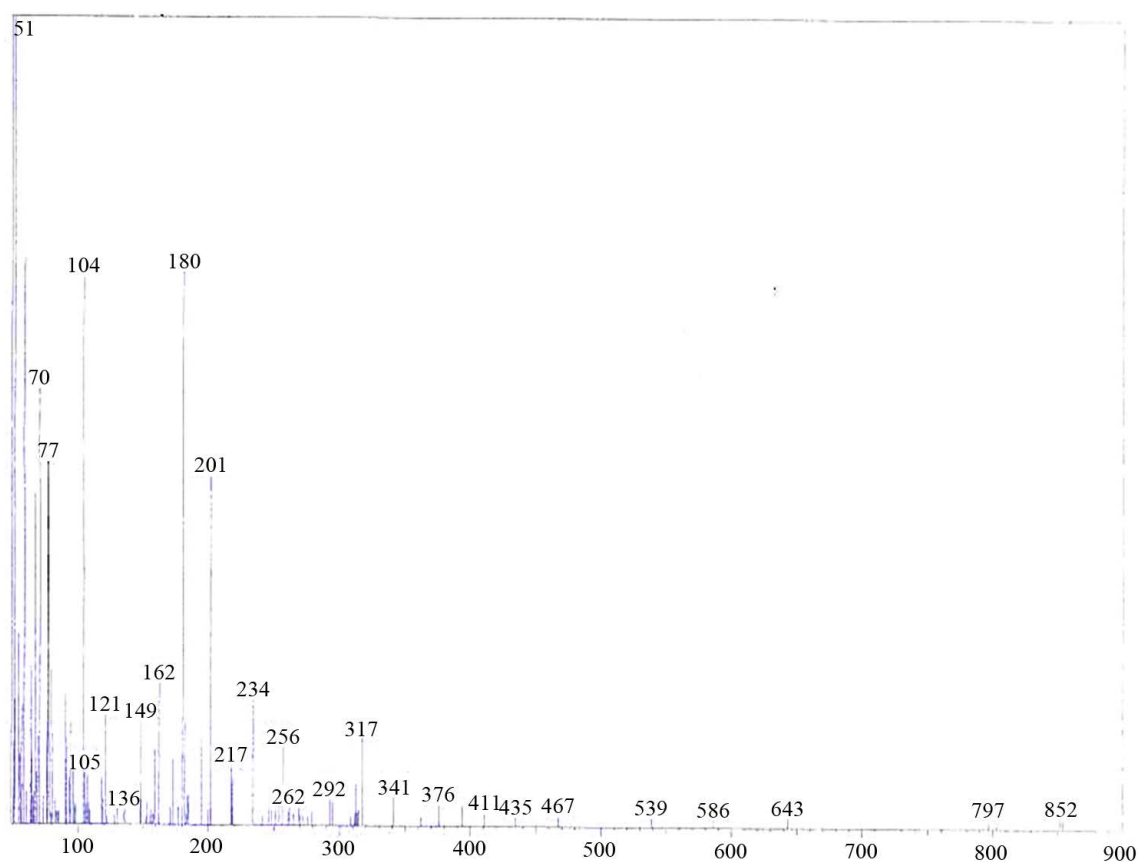

Figure 2. Mass spectrum of $\left[\mathrm{V}_{3} \mathrm{O}_{3}\left(\mathrm{~L}^{1}\right)\left(\mathrm{SO}_{4}\right)_{3}(\mathrm{EtOH})_{1 / 2}\left(\mathrm{H}_{2} \mathrm{O}\right)_{3 / 2}\right]$ complex.

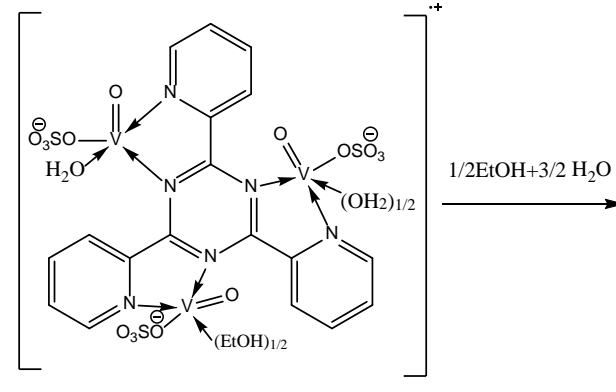

$\mathrm{m} / \mathrm{z}=852.3(851.4)(1.5 \%)$

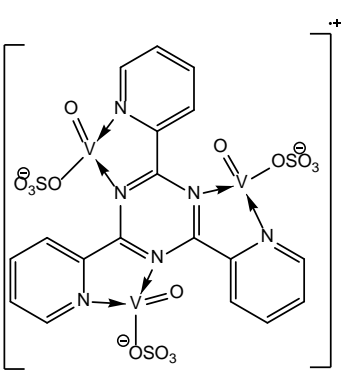

$+H^{+} \mathrm{m} / \mathrm{z}=802.7$ (801.3) (1.1\%)

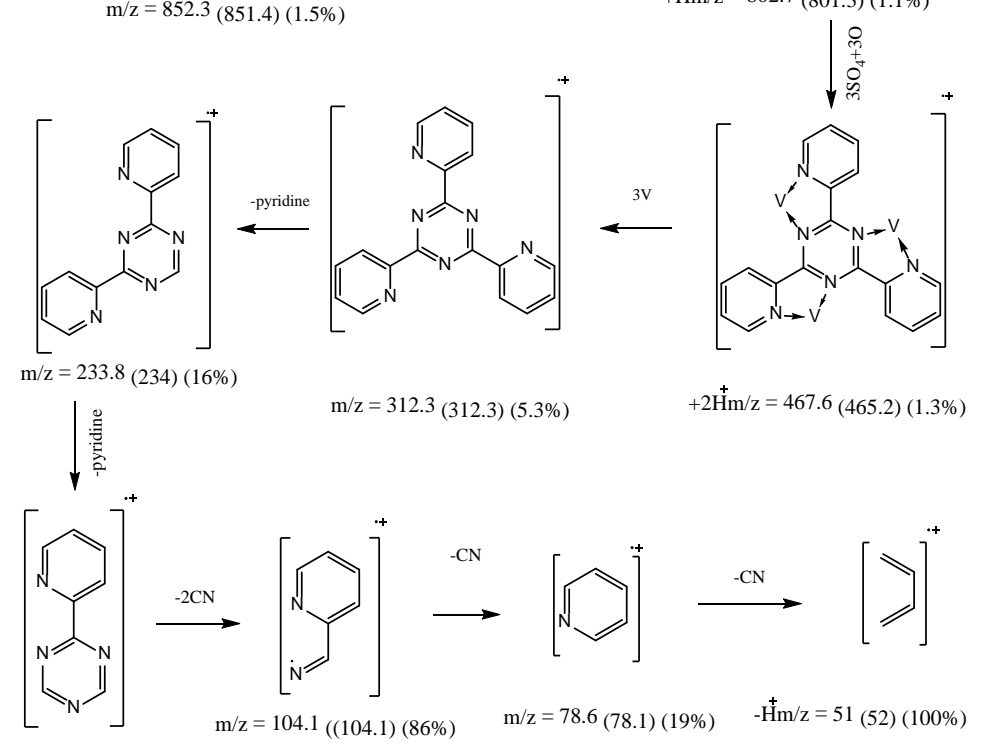

$\mathrm{m} / \mathrm{z}=156.2(156.2)(2 \%)$

Scheme 1. Fragmentation pattern of $\left[\mathrm{V}_{3} \mathrm{O}_{3}\left(\mathrm{~L}^{1}\right)\left(\mathrm{SO}_{4}\right)_{3}(\mathrm{EtOH})_{1 / 2}\left(\mathrm{H}_{2} \mathrm{O}\right)_{3 / 2}\right]$ complex. 
shown in (Figure S11). The fragmentation pattern of the complex is shown in (Figure S12). This suggests that the proposed structure for the complex is correct and has the chemical formula, $\mathrm{C}_{21} \mathrm{H}_{22} \mathrm{~N}_{6} \mathrm{O}_{12} \mathrm{~S}_{2} \mathrm{~V}_{2}$. The mass spectrum of the $\mathrm{V}^{4+}$ complex (1:1), $\left[\mathrm{VO}\left(\mathbf{L}^{1}\right) \mathrm{SO}_{4}\left(\mathrm{H}_{2} \mathrm{O}\right)_{3 / 2}\right] \cdot 2.5 \mathrm{H}_{2} \mathrm{O}$, at $120^{\circ} \mathrm{C}$ shows the molecular ion peak [m/z] at 547.6 and coincides with the theoretical value (547.39) as shown in (Figure S13). This suggests that the proposed structure for the complex is correct and has the chemical formula; $\mathrm{C}_{18} \mathrm{H}_{20} \mathrm{~N}_{6} \mathrm{SO}$. V. The fragmentation pattern of the $\mathrm{V}^{4+}$ complex (1:1) is shown in (Figure S14). The mass spectrum of the $\mathrm{V}^{4+}$ complex (1:2), $\left[\mathrm{V}_{2} \mathrm{O}_{2}\left(\mathbf{L}^{1}\right)\right.$ $\left.\left(\mathrm{SO}_{4}\right)_{2}\left(\mathrm{H}_{2} \mathrm{O}\right)\right] \cdot \mathrm{H}_{2} \mathrm{O}$, shows the molecular ion peak $[\mathrm{m} / \mathrm{z}]$ at 672.35 and coincides with the theoretical value (674.36) as shown in (Figure S15). The fragmentation pattern of the $\mathrm{V}^{4+}$ complex (1:2) is shown in (Figure S16). This suggests that the proposed structure for the complex is correct and has the chemical formula, $\mathrm{C}_{18} \mathrm{H}_{16} \mathrm{~N}_{6} \mathrm{~S}_{2} \mathrm{O}_{12} \mathrm{~V}_{2}$. Also, the results of elemental analyses and thermal analyses are taken as evidences for the proposed structures.

\subsection{Thermal Analysis}

The steps of decomposition, temperature extent and decomposition products and also the weight loss percentages of $\mathrm{V}^{4+}$ complexes are reported in Table 1. Figure 3 and (Figure S17-S20) show the TGA/DTG curves of the five metal complexes. The experimental weight loss values are in good agreement with the calculated values. In the TGA curve of the $\left[\mathrm{V}_{3} \mathrm{O}_{3}\left(\mathbf{L}^{1}\right)\left(\mathrm{SO}_{4}\right)_{3}(\mathrm{EtOH})_{1 / 2}\left(\mathrm{H}_{2} \mathrm{O}\right)_{3 / 2}\right]$ (3:1; M:L) (Figure 3) shows four decomposition stages. The first stage was in $27^{\circ} \mathrm{C}-263^{\circ} \mathrm{C}$ range with a loss corresponding to 1.5 coordinate $\mathrm{H}_{2} \mathrm{O}$ molecules and 1.5 EtOH molecule and $\mathrm{N}_{2}$ fragment (Found: 9.2\%; Calcd.: 9.3\%). The second step lies in the range $263^{\circ} \mathrm{C}-329^{\circ} \mathrm{C}$ corresponds to the loss of $\mathrm{NO}_{2}$ and $2 \mathrm{H}_{2}$ fragment (Found: 5.9\%; Calcd.: 6.0\%). The third step corresponds to

\begin{tabular}{|c|c|c|c|c|c|}
\hline \multirow{2}{*}{ Compound } & \multirow{2}{*}{ Decomposition Step } & \multirow{2}{*}{$\begin{array}{l}\text { Temperature } \\
\text { Range }\left({ }^{\circ} \mathrm{C}\right)\end{array}$} & \multirow{2}{*}{ Removes Species } & \multicolumn{2}{|c|}{ Wt. Loss } \\
\hline & & & & \% (Cacld.) & \% Found \\
\hline \multirow{5}{*}{$\begin{array}{c}{\left[\mathrm{V}_{3} \mathrm{O}_{3}\left(\mathbf{L}^{\mathbf{1}}\right)\left(\mathrm{SO}_{4}\right)_{3}(\mathrm{EtOH})_{1 / 2}\left(\mathrm{H}_{2} \mathrm{O}\right)_{3 / 2}\right]} \\
\left(\mathrm{C}_{19} \mathrm{H}_{18} \mathrm{~N}_{6} \mathrm{~S}_{3} \mathrm{O}_{17} \mathrm{~V}_{3}\right)\end{array}$} & $1^{\mathrm{st}}$ & $27-263$ & $1.5 \mathrm{H}_{2} \mathrm{O}+1 / 2 \mathrm{EtOH}+\mathrm{N}_{2}$ & 9.2 & 9.3 \\
\hline & $2^{\text {rd }}$ & $263-329$ & $\mathrm{NO}_{2}+2 \mathrm{H}_{2}$ & 5.9 & 6.0 \\
\hline & $3^{\text {rd }}$ & $329-449$ & $2 \mathrm{SO}_{4}+\mathrm{C}_{3} \mathrm{H}_{3}+\mathrm{CO}$ & 30.4 & 30.0 \\
\hline & $4^{\text {th }}$ & $449-598$ & $\mathrm{SO}_{4}+\mathrm{C}_{9} \mathrm{H}_{5}$ & 24.6 & 24.7 \\
\hline & Residue & $598-800$ & $\mathrm{~V}_{3} \mathrm{~N}_{3} \mathrm{C}_{5}$ & 30.0 & 30.0 \\
\hline \multirow{4}{*}{$\begin{array}{c}{\left[\mathrm{VO}\left(\mathbf{L}^{\mathbf{1}}\right)(2,4-\text { pentadionate })\right] \mathrm{Cl} \cdot 4 \mathrm{HCl}} \\
\left(\mathrm{C}_{23} \mathrm{H}_{23} \mathrm{~N}_{6} \mathrm{O}_{3} \mathrm{Cl} \mathrm{l}_{5} \mathrm{~V}\right)\end{array}$} & $1^{\text {st }}$ & $27-211$ & $2 \mathrm{HCl}$ & 11.1 & 11.4 \\
\hline & $2^{\text {nd }}$ & $211-398$ & $\mathrm{Cl}+2 \mathrm{HCl}+2 \mathrm{~N}_{2}+\mathrm{O}_{2}+\mathrm{CO}$ & 34.01 & 33.9 \\
\hline & $3^{\text {rd }}$ & $398-563$ & $\mathrm{C}_{17} \mathrm{H}_{9} \mathrm{~N}$ & 34.45 & 34.7 \\
\hline & Residue & $563-800$ & $\mathrm{C}_{5} \mathrm{H}_{10} \mathrm{NV}$ & 20.5 & 20.0 \\
\hline \multirow{5}{*}{$\begin{array}{l}{\left[\mathrm{V}_{2} \mathrm{O}_{2}\left(\mathbf{L}^{1}\right)\left(\mathrm{SO}_{4}\right)_{2}(\mathrm{EtOH})_{5 / 2}\right]} \\
\quad\left(\mathrm{C}_{23} \mathrm{H}_{27} \mathrm{~N}_{6} \mathrm{O}_{25 / 2} \mathrm{~S}_{2} \mathrm{~V}_{2}\right)\end{array}$} & $1^{\mathrm{st}}$ & $28-207$ & $1 / 2 \mathrm{EtOH}+\mathrm{C}$ & 4.7 & 4.8 \\
\hline & $2^{\text {rd }}$ & $208-343$ & $2 \mathrm{EtOH}+\mathrm{O}_{2}+\mathrm{N}_{2}+\mathrm{C}_{2} \mathrm{H}_{4}$ & 23.9 & 23.9 \\
\hline & $3^{\text {rd }}$ & $343-422$ & $\mathrm{SO}_{4}+\mathrm{CH}_{4}$ & 14.9 & 14.8 \\
\hline & $4^{\text {th }}$ & $422-565$ & $\mathrm{SO}_{4}+\mathrm{N}_{2}+2 \mathrm{H}_{2}$ & 17 & 17.3 \\
\hline & Residue & $565-800$ & $\mathrm{~V}_{2} \mathrm{~N}_{2} \mathrm{C}_{14}$ & 39.6 & 39.2 \\
\hline \multirow{4}{*}{$\begin{array}{c}{\left[\mathrm{VO}\left(\mathbf{L}^{1}\right) \mathrm{SO}_{4}\left(\mathrm{H}_{2} \mathrm{O}\right)_{3 / 2}\right] \cdot 2.5 \mathrm{H}_{2} \mathrm{O}} \\
\left(\mathrm{C}_{18} \mathrm{H}_{20} \mathrm{~N}_{6} \mathrm{SO}_{9} \mathrm{~V}\right)\end{array}$} & $1^{\text {st }}$ & $18-216$ & $2.5 \mathrm{H}_{2} \mathrm{O}$ & 8.23 & 8.5 \\
\hline & $2^{\text {rd }}$ & $216-443$ & $3 / 2 \mathrm{H}_{2} \mathrm{O}+\mathrm{SO}_{4}+\mathrm{C}_{5} \mathrm{H}_{5}$ & 34.4 & 34.5 \\
\hline & $3^{\text {rd }}$ & $443-574$ & $\mathrm{C}_{9} \mathrm{H}_{5} \mathrm{~N}_{5} \mathrm{O}$ & 36.4 & 35.9 \\
\hline & Residue & $574-1000$ & $\mathrm{C}_{4} \mathrm{H}_{2} \mathrm{NV}$ & 21 & 20.8 \\
\hline \multirow{4}{*}{$\begin{array}{l}{\left[\mathrm{V}_{2} \mathrm{O}_{2}\left(\mathrm{~L}^{1}\right)\left(\mathrm{SO}_{4}\right)_{2}\left(\mathrm{H}_{2} \mathrm{O}\right)\right] \cdot \mathrm{H}_{2} \mathrm{O}} \\
\quad\left(\mathrm{C}_{18} \mathrm{H}_{16} \mathrm{~N}_{6} \mathrm{~S}_{2} \mathrm{O}_{12} \mathrm{~V}_{2}\right)\end{array}$} & $1^{\mathrm{st}}+2^{\mathrm{nd}}$ & $19-395$ & $2 \mathrm{H}_{2} \mathrm{O}+\mathrm{SO}_{4}$ & 19.6 & 20.9 \\
\hline & $3^{\text {rd }}$ & $395-448$ & $\mathrm{SO}_{4}+\mathrm{CH}$ & 16.2 & 15.8 \\
\hline & $4^{\text {th }}$ & $448-525$ & $\mathrm{C}_{14} \mathrm{H}_{5} \mathrm{~N}_{4} \mathrm{O}_{2}$ & 38.7 & 38.2 \\
\hline & Residue & $525-1000$ & $\mathrm{C}_{3} \mathrm{H}_{6} \mathrm{~N}_{2} \mathrm{~V}_{2}$ & 25.5 & 25.1 \\
\hline
\end{tabular}




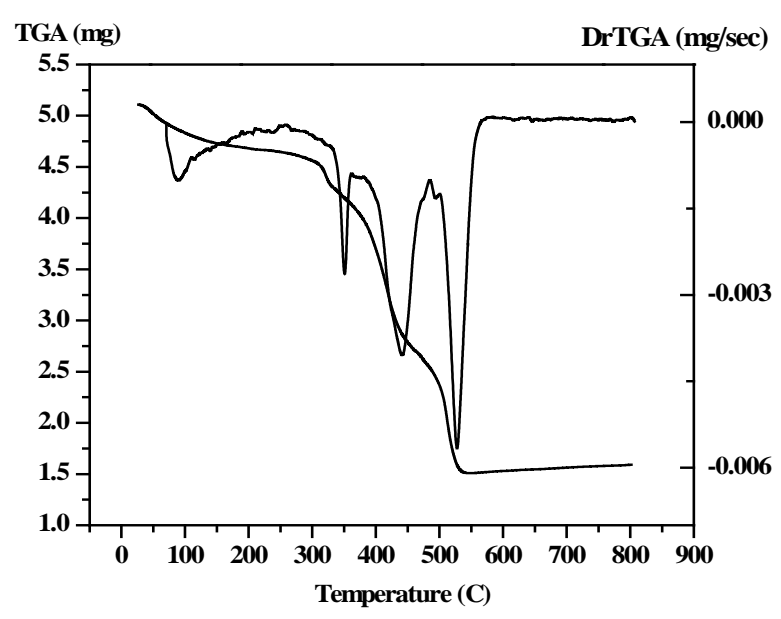

Figure 3. The TGA curve of the $\left[\mathrm{V}_{3} \mathrm{O}_{3}\left(\mathrm{~L}^{1}\right)\left(\mathrm{SO}_{4}\right)_{3}(\mathrm{EtOH})_{1 / 2}\right.$ $\left.\left(\mathrm{H}_{2} \mathrm{O}\right)_{3 / 2}\right]$.

$2 \mathrm{SO}_{4}$ and $\mathrm{C}_{3} \mathrm{H}_{3}$ and $\mathrm{CO}$ fragments are (Found: $30.4 \%$; Calcd.: $30.0 \%$ ) in range $329^{\circ} \mathrm{C}-449^{\circ} \mathrm{C}$. The fourth step attributes (Found: 24.7\%; Calcd.: (24.7\%) refers to $\mathrm{SO}_{4}$ and $\mathrm{C}_{9} \mathrm{H}_{5}$ fragment. The residual part (Found: $30.0 \%$; Calcd.: $30.0 \%)$ refers to $\mathrm{V}_{3} \mathrm{~N}_{3} \mathrm{C}_{5}$. Secondly, the TGA curve of $\left[\mathrm{VO}\left(\mathbf{L}^{1}\right)(2,4\right.$-pentadionate)]Cl.4HCl (Figure S17) shows the first step in $27^{\circ} \mathrm{C}-211^{\circ} \mathrm{C}$ range with a loss corresponding to $2 \mathrm{HCl}$ fragment (Found: $11.1 \%$; Calcd.: $11.4 \%$ ). The second step lies in the range $211^{\circ} \mathrm{C}-398^{\circ} \mathrm{C}$ corresponds to the loss of $\mathrm{Cl}, 2 \mathrm{HCl}, 2 \mathrm{~N}_{2}, \mathrm{O}_{2}$ and $\mathrm{CO}$ fragments (Found: 34.01\%; Calcd.: 33.9\%). The mass loss corresponds to the main skeleton of complex $\mathrm{C}_{17} \mathrm{H}_{9} \mathrm{~N}$ are (Found: $34.5 \%$; Calcd.: $34.7 \%$ ) in the $398^{\circ} \mathrm{C}-563^{\circ} \mathrm{C}$ range. The residual part (Found: 20.5\%; Calcd.: 20.0\%) refers to $\mathrm{C}_{5} \mathrm{H}_{10} \mathrm{VN}$ fragment. Also, the TGA of $\left[\mathrm{V}_{2} \mathrm{O}_{2}\left(\mathbf{L}^{\mathbf{1}}\right)\left(\mathrm{SO}_{4}\right)_{2}(\mathrm{EtOH})_{5 / 2}\right]$ (Figure S18) shows the first step in $28^{\circ} \mathrm{C}-207^{\circ} \mathrm{C}$ range with a loss corresponding to $1 / 2 \mathrm{EtOH}$ and carbon fragment (Found: $4.7 \%$; Calcd.: $4.8 \%$ ). The second step lies in the range $208^{\circ} \mathrm{C}-343^{\circ} \mathrm{C}$ corresponds to the loss of $2 \mathrm{EtOH}, \mathrm{O}_{2}, \mathrm{~N}_{2}$ and $\mathrm{C}_{2} \mathrm{H}_{4}$ fragments (Found: 23.9\%; Calcd.: 23.9\%). The third step lies in the range $343^{\circ} \mathrm{C}-422^{\circ} \mathrm{C}$ corresponds to the loss of $\mathrm{SO}_{4}$ and $\mathrm{CH}_{4}$ fragments (Found: 14.9\%; Calcd.: 14.8\%). The fourth step corresponds to loss of $\mathrm{SO}_{4}, \mathrm{~N}_{2}$ and $2 \mathrm{H}_{2}$ (Found: $17 \%$; Calcd.: $17.3 \%$ ) in the $422^{\circ} \mathrm{C}-565^{\circ} \mathrm{C}$ range. The residual part (Found: 39.6\%; Calcd.: 39.2\%) refers to $\mathrm{C}_{14} \mathrm{~V}_{2} \mathrm{~N}_{2}$ fragment. Additionally The TGA curve of $\left[\mathrm{VO}\left(\mathrm{L}^{1}\right)\left(\mathrm{SO}_{4}\right)\left(\mathrm{H}_{2} \mathrm{O}\right)_{3 / 2}\right] \cdot 2.5 \mathrm{H}_{2} \mathrm{O}$ (1:1; M:L) (Figure S19) shows three stages of decomposition within the temperature range $18^{\circ} \mathrm{C}-1000^{\circ} \mathrm{C}$. The first stage in $18^{\circ} \mathrm{C}-$ $216^{\circ} \mathrm{C}$ range corresponded to the loss of 2.5 lattice water molecules (Found: 8.5\%; Calcd.: 8.23\%). The second step lies in the range $216^{\circ} \mathrm{C}-443^{\circ} \mathrm{C}$ corresponds to the loss of 1.5 coordinated water molecules (hydrogen bond), $\mathrm{SO}_{4}$ group and $\mathrm{C}_{5} \mathrm{H}_{5}$ fragment (Found: $34.5 \%$; Calcd.: $34.4 \%$ ). In the third stage, the mass loss attributes to $\mathrm{C}_{9} \mathrm{H}_{5} \mathrm{~N}_{5} \mathrm{O}$ are (Found: $35.9 \%$; Calcd.: $36.4 \%$ ) in range $443^{\circ} \mathrm{C}-574^{\circ} \mathrm{C}$. The residual part (Found: $20.8 \%$; Calcd.: $21 \%)$ refers to VN and $\mathrm{C}_{4} \mathrm{H}_{2}$ fragment. Finally, the TGA curve of $\left[\mathrm{V}_{2} \mathrm{O}_{2}\left(\mathbf{L}^{1}\right)\left(\mathrm{SO}_{4}\right)_{2}\left(\mathrm{H}_{2} \mathrm{O}\right)\right] \cdot \mathrm{H}_{2} \mathrm{O}(2: 1$; M:L) (Figure S20) shows four stages of decomposition within the temperature range $25^{\circ} \mathrm{C}-1000^{\circ} \mathrm{C}$. The first and second steps in $19^{\circ} \mathrm{C}-395^{\circ} \mathrm{C}$ range correspond to one lattice $\mathrm{H}_{2} \mathrm{O}$ molecule, one coordinated $\mathrm{H}_{2} \mathrm{O}$ molecule and coordinated $\mathrm{SO}_{4}$ group (Found: $20.9 \%$; Calcd.: $19.6 \%$ ). The third step lies in the range $395^{\circ} \mathrm{C}-448^{\circ} \mathrm{C}$ corresponds to the loss of other coordinated $\mathrm{SO}_{4}$ group and $\mathrm{CH}$ fragment (Found: $15.8 \%$; Calcd.: $16.2 \%$ ). The mass loss corresponds to the main skeleton of complex $\mathrm{C}_{14} \mathrm{H}_{5} \mathrm{~N}_{4} \mathrm{O}_{2}$ are (Found: $38.2 \%$; Calcd.: $38.7 \%$ ) in the $448^{\circ} \mathrm{C}$ $525^{\circ} \mathrm{C}$ range. The residual part (Found: 25.1\%; Calcd.: 25.5\%) refers to $\mathrm{V}_{2} \mathrm{~N}_{2}$ and $\mathrm{C}_{3} \mathrm{H}_{6}$ fragments.

\subsection{Electron Spin Resonance}

The ESR spectra of the researched complexes show just an intense and broad signal without hyperfine splitting. The nonappearance of vanadium hyperfine coupling is regular in solid state [28] and is credited to the simultaneous flipping of neighbouring electron spins [29] [30] or because of strong exchange interactions, which average out the collaboration with the nuclei. The solid ESR spectra of V(IV) complexes, $\left[\mathrm{V}_{3} \mathrm{O}_{3}\left(\mathbf{L}^{\mathbf{1}}\right)\left(\mathrm{SO}_{4}\right)_{3}(\mathrm{EtOH})_{1 / 2}\right.$ $\left.\left(\mathrm{H}_{2} \mathrm{O}\right)_{3 / 2}\right]$, [VO( $\left.\mathbf{L}^{1}\right)\left(2,4\right.$-pentadionate) $\mathrm{Cl} \cdot 4 \mathrm{HCl}$ and $\left[\mathrm{VO}\left(\mathbf{L}^{1}\right) \mathrm{SO}_{4}\left(\mathrm{H}_{2} \mathrm{O}\right)_{3 / 2}\right] \cdot 2.5 \mathrm{H}_{2} \mathrm{O}$, are shown in Figure 4 and (Figure S21-S22), respectively,. The shape of the spectra is predictable with square-pyramidal environment around V(IV) ion and the lower g value for the investigated complexes, when contrasted with that of free electron 


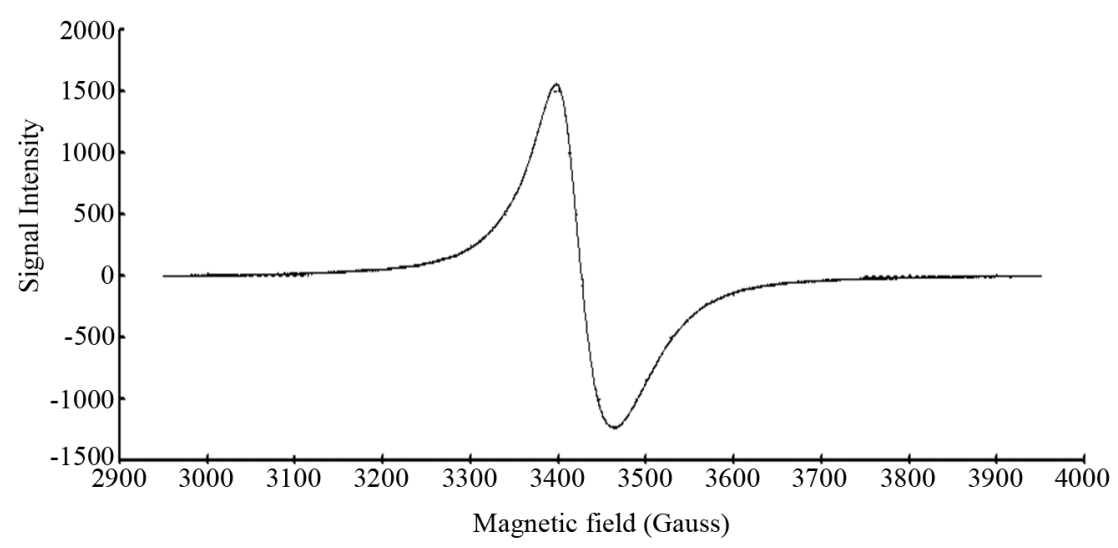

Figure 4. X-band ESR spectrum of $\left[\mathrm{V}_{3} \mathrm{O}_{3}\left(\mathrm{~L}^{1}\right)\left(\mathrm{SO}_{4}\right)_{3}(\mathrm{EtOH})_{1 / 2}\left(\mathrm{H}_{2} \mathrm{O}\right)_{3 / 2}\right]$.

( $g=2.0023$ ) uncovering a considerable covalency of metal ligand bonding with $\mathrm{d}_{\mathrm{x} 2-\mathrm{y} 2}$ as the ground-statenormal for square pyramidal stereochemistry as appeared in Table 2. The decrease of the g value than that of the free-electron value (2.0023) is an estimated measure of the ligand field strength; the stronger the ligand field the littler the reduction in the $g$ value and the other way around. The $|g|$, g $\perp$ and $|\mathrm{A}|$ values are measured from the spectra, which are in good agreement for a square-pyramidal structure. The high value of $\boldsymbol{\alpha}^{2}$ for the [ $\mathrm{VO}\left(\mathbf{L}^{1}\right)(2,4$-pentadionate) $\mathrm{Cl} \cdot 4 \mathrm{HCl}(0.621)$ suggests the ionic nature of this complex. On the other hand the low values of $\alpha^{2}$ for $\left[\mathrm{V}_{3} \mathrm{O}_{3}\left(\mathbf{L}^{1}\right)\left(\mathrm{SO}_{4}\right)_{3}(\mathrm{EtOH})_{1 / 2} \cdot\left(\mathrm{H}_{2} \mathrm{O}\right)_{3 / 2}\right](0.2499)$ and $\left[\mathrm{VO}\left(\mathbf{L}^{1}\right) \mathrm{SO}_{4}\left(\mathrm{H}_{2} \mathrm{O}\right)_{3 / 2}\right] \cdot 2.5 \mathrm{H}_{2} \mathrm{O}(0.2079)$ indicate the covalent nature of these complexes.

\subsection{Stoichiometry of the Metal Complexes}

The stoichiometry of $\mathrm{V}^{4+}-\mathbf{L}^{1}$ complex was resolved utilizing continuous variation (CV) and molar ratio methods (MR). In continuous variation method the absorbance of the prepared solutions of $\mathrm{V}^{4+}$ and $\mathbf{L}^{\mathbf{1}}$ with total molar concentration constant $6 \times 10^{-3} \mathrm{M}$ and at $604 \mathrm{~nm}$ were recorded. The plot of absorbance as a function of the mole fraction of $\mathbf{L}^{\mathbf{1}}$ estimated that the complex has a maximum absorbance at 0.5 mol fraction providing evidence for 1:1 (M:L) complex (Figure 5). In molar ratio method, the absorbance of prepared solutions with constant metal ion concentration was recorded at $604 \mathrm{~nm}$ and plotted versus the molar ratio [L]/[M] (Figure 6). The curve consists of two linear portions crossing at 1:1 M:L species. The stability constant of the formed complex was computed from only one method (CV) by evaluating the degree of complex formation was determined by applying the accompanying formula [31] [32]:

$$
K_{f}=\frac{A / A_{m}}{\left(1-A / A_{m}\right)^{n+1} n^{n} C^{n}}
$$

where $A, A_{m}, n$ and $C$ are the absorbance of the partially formed complex, the fully formed complex, stoichiometry ratio and concentration of metal utilized, respectively. The $K_{f}, \log \beta$ and $\Delta \mathrm{G}^{\circ}$ values obtained from the continuous variation method are $1492.11,-3.17$ and -18105.96 , respectively.

\subsection{Electronic and Magnetic Measurements}

The electronic spectra of the complexes were recorded in Nujol mull and DMSO. The electronic spectrum of [VO( $\left.\left(\mathbf{L}^{1}\right) \mathrm{SO}_{4}\left(\mathrm{H}_{2} \mathrm{O}\right)_{3 / 2}\right] \cdot 2.5 \mathrm{H}_{2} \mathrm{O}$ (Figure 7) shows six bands. The first three bands at 32,679, 25,773 and 22,935 $\mathrm{cm}^{-1}$ are attributed to charge-transfer of the type $\mathrm{L} \rightarrow \mathrm{M}$. The last three bands at 16,611, 19,230 and 20,576 $\mathrm{cm}^{-1}$ are assigned to d-d transition ${ }^{2} \mathrm{~B}_{2}\left(\mathrm{~d}_{\mathrm{xy}} \rightarrow \mathrm{d}_{\mathrm{xz}}, \mathrm{d}_{\mathrm{yz}}\right) \rightarrow{ }^{2} \mathrm{E}$, ${ }^{2} \mathrm{~B}_{2}\left(\mathrm{~d}_{\mathrm{xy}} \rightarrow \mathrm{d}_{\mathrm{x} 2-\mathrm{y} 2}\right) \rightarrow{ }^{2} \mathrm{~B}_{1}$ and ${ }^{2} \mathrm{~B}_{2}\left(\mathrm{~d}_{\mathrm{xy}} \rightarrow \mathrm{d}_{\mathrm{z}}{ }^{2}\right) \rightarrow{ }^{2} \mathrm{~A}_{1}$ transitions, respectively [33]. The data of IR spectra gathering with electronic spectra suggest a square-pyramidal geometry around the $\mathrm{V}^{4+}$ ion [34]. But, the value of the magnetic moment of the complex is 2.7 B.M which is higher than the proposed for $\mathrm{d}^{1}$-system; recommending an orbital contribution [35].

The electronic spectrum of $\left[\mathrm{V}_{2} \mathrm{O}_{2}\left(\mathbf{L}^{1}\right)\left(\mathrm{SO}_{4}\right)_{2}\left(\mathrm{H}_{2} \mathrm{O}\right)\right] \cdot \mathrm{H}_{2} \mathrm{O}$ (Figure S23) estimates three bands at 166,666, 19,157 and 23,809 $\mathrm{cm}^{-1}$ assigned to d-d transition ${ }^{2} \mathrm{~B}_{2}\left(\mathrm{~d}_{\mathrm{xy}} \rightarrow \mathrm{d}_{\mathrm{xz}}, \mathrm{d}_{\mathrm{yz}}\right) \rightarrow{ }^{2} \mathrm{E},{ }^{2} \mathrm{~B}_{2}\left(\mathrm{~d}_{\mathrm{xy}} \rightarrow \mathrm{d}_{\mathrm{x} 2-\mathrm{y} 2}\right) \rightarrow{ }^{2} \mathrm{~B}_{1}$ and ${ }^{2} \mathrm{~B}_{2}$ 


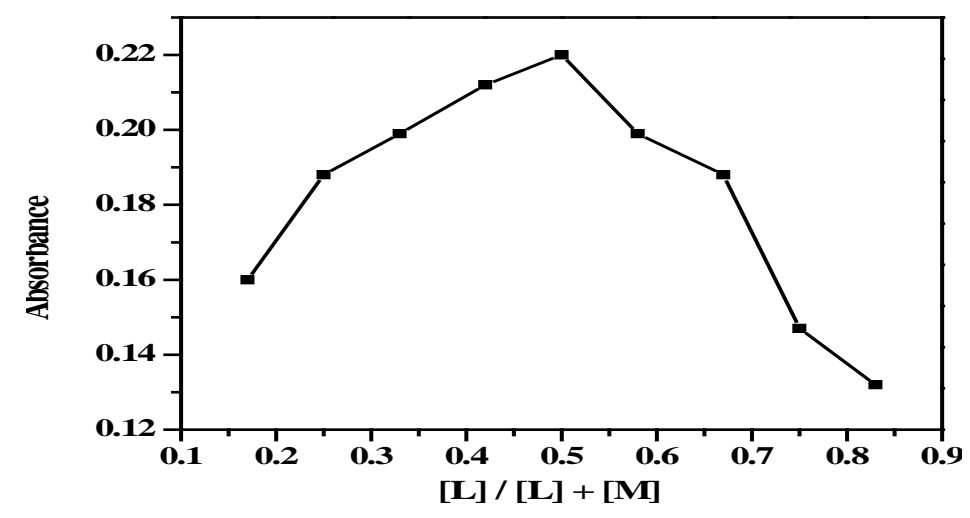

Figure 5. Continuous variation method of $\mathrm{V}^{4+}-\mathbf{L}^{\mathbf{1}}$.

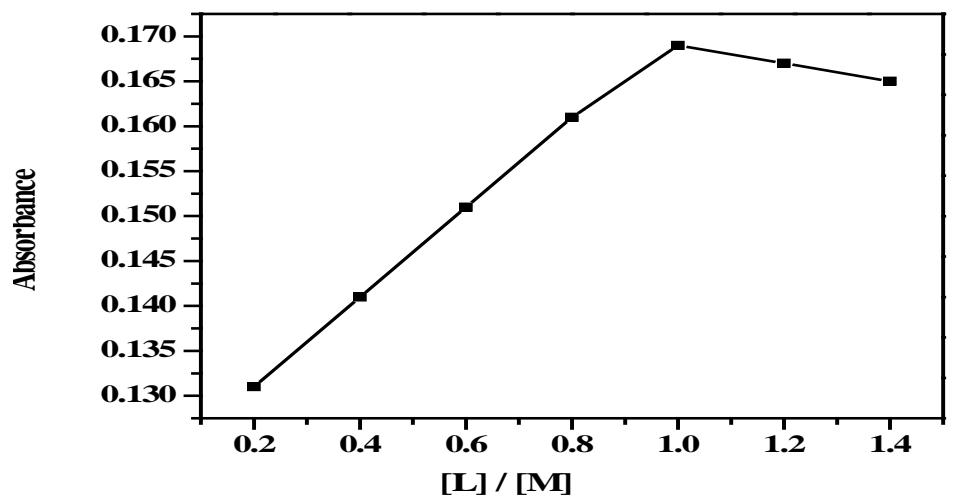

Figure 6. Molar ratio method of $\mathrm{V}^{4+}-\mathbf{L}^{\mathbf{1}}$.

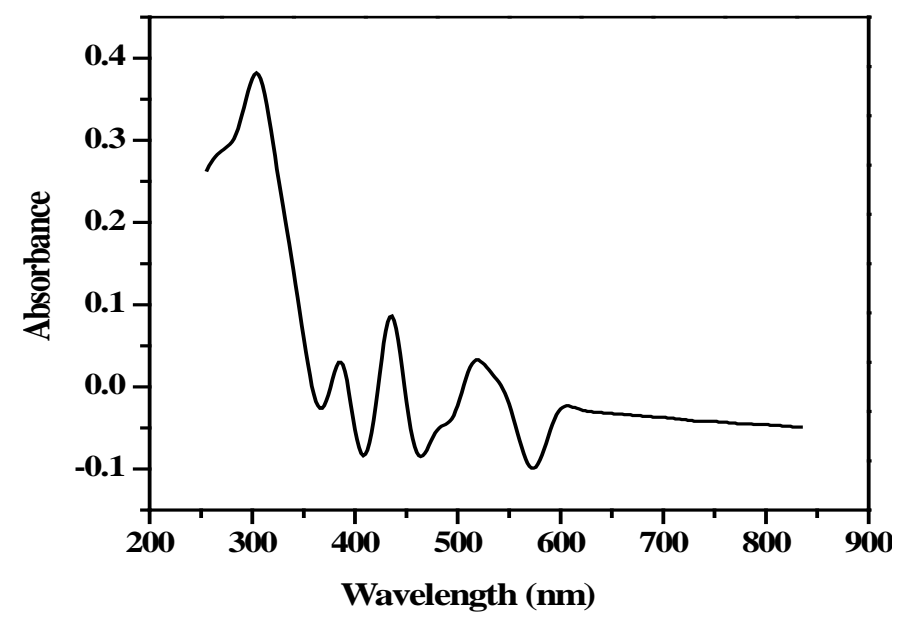

Figure 7. Electronic spectrum of $\left[\mathrm{VO}\left(\mathrm{L}^{1}\right) \mathrm{SO}_{4}\left(\mathrm{H}_{2} \mathrm{O}\right)_{3 / 2}\right] \cdot 2.5 \mathrm{H}_{2} \mathrm{O}$.

Table 2. Magnetic measurements of V(IV) complexes.

\begin{tabular}{|c|c|c|c|c|c|c|c|}
\hline No. & Compound & $\mathbf{g}_{\perp}$ & $\mathbf{g}_{\|}$ & $\mathbf{g}_{\mathrm{av}}$ & $\mathbf{A}_{11}$ & $\alpha^{2}$ & $\beta^{2}$ \\
\hline 1 & {$\left[\mathrm{VO}\left(\mathbf{L}^{\mathbf{1}}\right)(2,4\right.$-pentadionate $\left.)\right] \mathrm{Cl} \cdot 4 \mathrm{HCl}$} & 1.98 & 2.011 & 1.99 & 0.02118 & 0.621 & ---- \\
\hline 2 & {$\left[\mathrm{~V}_{3} \mathrm{O}_{3}\left(\mathbf{L}^{\mathbf{1}}\right)\left(\mathrm{SO}_{4}\right)_{3}(\mathrm{EtOH})_{1 / 2}\left(\mathrm{H}_{2} \mathrm{O}\right)_{3 / 2}\right]$} & 1.97 & 1.99 & 1.98 & $8.5 \times 10^{-3}$ & 0.2499 & 0.7909 \\
\hline 3 & {$\left[\mathrm{VO}\left(\mathbf{L}^{1}\right) \mathrm{SO}_{4}\left(\mathrm{H}_{2} \mathrm{O}\right)_{3 / 2}\right] \cdot 2.5 \mathrm{H}_{2} \mathrm{O}$} & 1.96 & 1.98 & 1.97 & $7.5 \times 10^{-3}$ & 0.2079 & ---- \\
\hline
\end{tabular}


$\left(\mathrm{d}_{\mathrm{xy}} \rightarrow \mathrm{d}_{\mathrm{z}}{ }^{2}\right) \rightarrow{ }^{2} \mathrm{~A}_{1}$ transitions, respectively [33], in a square-pyramidal geometry around the $\mathrm{V}^{4+}$ ion [34]. Also, the bands at 34,965, 31,847 and 25,641 $\mathrm{cm}^{-1}$ are attributed to charge-transfer of the type $\mathrm{L} \rightarrow \mathrm{M}$. Moreover, the value of the corrected magnetic moment $\left(\mu_{\text {eff }}=2.8 \mathrm{BM}\right)$ is evaluated per each $\mathrm{V}^{4+}$ ion [36]. The electronic spectrum of $\left[\mathrm{V}_{3} \mathrm{O}_{3}\left(\mathbf{L}^{\mathbf{1}}\right)\left(\mathrm{SO}_{4}\right)_{3}(\mathrm{EtOH})_{1 / 2}\left(\mathrm{H}_{2} \mathrm{O}\right)_{3 / 2}\right]$ Figure S24) reveals five bands at 35,971, 33,333, 24,509, 17,361 and 12,987 $\mathrm{cm}^{-1}$. The first two bands are attributed to charge-transfer of the type $\mathrm{L} \rightarrow \mathrm{M}$ while the last three bands are assigned to d-d transitions of a square-pyramidal geometry around the $\mathrm{V}^{4+}$ ion [33]. The trinuclear complex shows subnormal magnetic susceptibility value $\left(\mu_{\text {eff }}=2.8 \mathrm{~B} . \mathrm{M}\right)$ at room temperature. It might be ascribed to that the unpaired electron in the $\mathrm{d}_{\mathrm{xy}}$ orbital of the adjacent vanadium atoms, so this interaction prompts subnormal magnetic moment at room temperature [37]. The electronic spectrum of $\left[\mathrm{VO}\left(\mathbf{L}^{\mathbf{1}}\right)(2,4\right.$-pentadionate)] $\mathrm{Cl} \cdot 4 \mathrm{HCl}$ complex (Figure S25) reveals two bands at 32,258, 29,240 $\mathrm{cm}^{-1}$ are characterized for charge-transfer of the type $\mathrm{L} \rightarrow \mathrm{M}$. Also, three bands at 12,594, 14,535 and 20,747 $\mathrm{cm}^{-1}$ are for ${ }^{2} \mathrm{~B}_{2}\left(\mathrm{~d}_{\mathrm{xy}} \rightarrow \mathrm{d}_{\mathrm{xz}}, \mathrm{d}_{\mathrm{yz}}\right) \rightarrow{ }^{2} \mathrm{E},{ }^{2} \mathrm{~B}_{2}$ $\left(\mathrm{d}_{\mathrm{xy}} \rightarrow \mathrm{d}_{\mathrm{x} 2-\mathrm{y} 2}\right) \rightarrow{ }^{2} \mathrm{~B}_{1}$ and ${ }^{2} \mathrm{~B}_{2}\left(\mathrm{~d}_{\mathrm{xy}} \rightarrow \mathrm{d}_{\mathrm{z}}{ }^{2}\right) \rightarrow{ }^{2} \mathrm{~A}_{1}$ transitions respectively, in a square-pyramidal geometry around the $\mathrm{V}^{4+}$ ion [33]. The electronic spectrum of $\left[\mathrm{V}_{2} \mathrm{O}_{2}\left(\mathbf{L}^{1}\right)\left(\mathrm{SO}_{4}\right)_{2}(\mathrm{EtOH})_{5 / 2}\right]$ complex (Figure S26) shows five bands. The bands at 36,232 and 33,557 $\mathrm{cm}^{-1}$ are attributed to charge-transfer of the type $\mathrm{L} \rightarrow \mathrm{M}$, in addition tothe bands at 12,500, 16,891 and 27,624 $\mathrm{cm}^{-1}$ are assigned to $\mathrm{d}-\mathrm{d}$ transition ${ }^{2} \mathrm{~B}_{2}\left(\mathrm{~d}_{\mathrm{xy}} \rightarrow \mathrm{d}_{\mathrm{xz}}, \mathrm{d}_{\mathrm{yz}}\right) \rightarrow{ }^{2} \mathrm{E},{ }^{2} \mathrm{~B}_{2}\left(\mathrm{~d}_{\mathrm{xy}} \rightarrow\right.$ $\left.\mathrm{d}_{\mathrm{x} 2-\mathrm{y} 2}\right) \rightarrow{ }^{2} \mathrm{~B}_{1}$ and ${ }^{2} \mathrm{~B}_{2}\left(\mathrm{~d}_{\mathrm{xy}} \rightarrow \mathrm{d}_{\mathrm{z}}{ }^{2}\right) \rightarrow{ }^{2} \mathrm{~A}_{1}$ transitions respectively, in a square-pyramidal geometry around the $\mathrm{V}^{4+}$ ion [33]. Moreover, the value of the corrected magnetic moment ( $\mu_{\text {eff }}=3.01 \mathrm{BM}$ ) per each $\mathrm{V}^{4+}$ ion is taken an evidence for existence of two vanadium atoms [36].

\subsection{Computational Studies}

We performed cluster calculations utilizing $\mathrm{DMOL}^{3}$ program [38] in Materials Studio package [39], which is intended for the realization of vast scale density functional theory (DFT) calculations. DFT semi-core pseudopods (dspp) calculations were performed with the twofold numerical basis in addition to plus polarization functional (DNP). The DNP basis sets are of comparable quality to 6-31G Gaussian basis sets [40]. The molecular structure alongside atom numbering of the ligand metal complexes is appeared in Figure 8 and (Figure S27-S32). Analysis of the data (Tables S1-S12) involving the bond lengths and bond angles proposes the accompanying remarks.

Vanadium complexes have a square-pyramidal structure. All the active groups participating in coordination where have bonds longer than that as of now exist in the ligand (like $\mathrm{C}=\mathrm{N}$ ) because of $\mathrm{M}-\mathrm{N}$ bond formation which makes the $\mathrm{C}-\mathrm{N}$ and $\mathrm{C}=\mathrm{N}$ bond weaker likewise, The bond angles in the complexes are very close to a square-pyramidal geometry. In the event of

1) $\left[\mathrm{V}_{3} \mathrm{O}_{3}\left(\mathbf{L}^{1}\right)\left(\mathrm{SO}_{4}\right)_{3}(\mathrm{EtOH})_{1 / 2}\left(\mathrm{H}_{2} \mathrm{O}\right)_{3 / 2}\right]$ complex (Figure 8), $\mathbf{L}^{1}$ acts as a bidentate style coordinating via $\mathrm{N}(8)$ triaz, N(10)triaz, N(12)triaz, N(12)py, N(19)py, N(24)triaz atoms. The $\mathrm{SO}_{4}$ groups, EtOH and $\mathrm{H}_{2} \mathrm{O}$ molecules finish the square-pyramidal structure around the three vanadium atoms. There is an expansive variety in $\mathrm{C}(11)-\mathrm{N}(12)$ triaz, N(10)triaz-C(11), C(9)-N(10)triaz, N(8)triaz-C(9), N(12)triaz-C(7) and C(7)-N(8)triaz, N(2) py-C(3), N(24)py-C(14) and N(19)py-C(13)bond lengths. The bond angles of the $\mathbf{L}^{1}$ moiety are modified upon coordination; the biggest change influences $\mathrm{C}(23)-\mathrm{N}(24)$ py- $\mathrm{C}(14), \mathrm{C}(18)-\mathrm{N}(19) \mathrm{py}-\mathrm{C}(13), \mathrm{C}(11)-\mathrm{N}(12)$ triaz-C(7), N(12)triaz-C(11)-N(10)triaz, C(11)-N(10)triaz-C(9), N(10)triaz-C(9)-N(8)triaz, C(9)-N(8)triaz-C(7), N(12)py$\mathrm{C}(7)-\mathrm{N}(8)$ triaz and $\mathrm{C}(3)-\mathrm{N}(2) \mathrm{py}-\mathrm{C}(1)$ which are lessened or expanded on complex formation as a result of bonding.

2) $\operatorname{In}\left[\mathrm{VO}\left(\mathbf{L}^{\mathbf{1}}\right)(2,4\right.$-pentadionate) $] \mathrm{Cl} \cdot 4 \mathrm{HCl}$ complex (Figure S28), $\mathbf{L}^{\mathbf{1}}$ serves in a bidentate manner coordinating by means of $\mathrm{N}(8)$ triaz and $\mathrm{N}(2)$ py atoms. There is a vast variety in $\mathrm{N}(8)$ triaz-C(9), $\mathrm{C}(7)-\mathrm{N}(8)$ triaz, $\mathrm{C}(3)-\mathrm{C}(7)$, $\mathrm{N}(2)$ py-C(3) and C(1)-N(2)py bond lengths. The bond angles of $\mathbf{L}^{1}$ moiety are modified to some degree upon coordination; the biggest change impacts $\mathrm{C}(7)-\mathrm{C}(3)-\mathrm{N}(2)$ py, $\mathrm{C}(3)-\mathrm{N}(2)$ py- $\mathrm{C}(1)$, $\mathrm{N}(8)$ triaz-C(7)-C(3), and $\mathrm{C}(9)-\mathrm{N}(8)$ triaz-C(7) which are diminished or expanded on complex development as an outcome of bonding.

3) Also, $\left[\mathrm{V}_{2} \mathrm{O}_{2}\left(\mathbf{L}^{1}\right)\left(\mathrm{SO}_{4}\right)_{2}(\mathrm{EtOH})_{5 / 2}\right]$ (Figure S29), $\mathbf{L}^{\mathbf{1}}$ is a bi-dentate ligand coordinating via $\mathrm{N}(8)$ triaz, $\mathrm{N}(12)$ triaz, $\mathrm{N}(2)$ py and $\mathrm{N}(19)$ py atoms. There is a vast variety in $\mathrm{C}(18)-\mathrm{N}(19) \mathrm{py}, \mathrm{N}(19)$ py-C(14), $\mathrm{C}(11)-\mathrm{C}(14)$, C(11)-N(12)triaz, N(8)triaz-C(9), C(7)-N(8)triaz, C(3)-C(7), N(2)py-C(3), C(1)-N(2)py and N(12)triaz-C(7) bond lengths. The bond angles of the TPTZ moiety are modified to some degree upon coordination; the biggest change influences $\mathrm{C}(18)-\mathrm{N}(19) \mathrm{py}-\mathrm{C}(14), \mathrm{C}(11)-\mathrm{N}(12)$ triaz-C(7), $\mathrm{C}(14)-\mathrm{C}(11)-\mathrm{N}(12)$ triaz, N(12)triaz-C(11)$\mathrm{N}(10)$ triaz, $\mathrm{C}(9)-\mathrm{N}(8)$ triaz-C(7), $\mathrm{C}(7)-\mathrm{C}(3)-\mathrm{N}(2)$ py, $\mathrm{C}(3)-\mathrm{N}(2) \mathrm{py}-\mathrm{C}(1)$ and $\mathrm{N}(8)$ triaz-C(7)-C(3)which are lessened or expanded on complex arrangement as a result of holding. 
4) $\mathbf{L}^{\mathbf{1}}$ in $\left[\mathrm{V}_{2} \mathrm{O}_{2}\left(\mathbf{L}^{\mathbf{1}}\right)\left(\mathrm{SO}_{4}\right)_{2}(\mathrm{EtOH})_{3 / 2}\left(\mathrm{H}_{2} \mathrm{O}\right)_{1 / 2}\right]$ (Figure S30), serves in a bidentate manner coordinating by means of $\mathrm{N}(8)$ triaz, $\mathrm{N}(12)$ triaz, $\mathrm{N}(4)$ py and $\mathrm{N}(15)$ py atoms. There is an expansive variety in $\mathrm{C}(13)-\mathrm{N}(15)$ py, $\mathrm{C}(9)-\mathrm{C}(13)$, $\mathrm{N}(8)$ triaz-C(9), C(7)-N(8)triaz, N(4)py-C(5), C(3)-C(7) and C(3)-N(4)py bond lengths. The bond angles of $\mathbf{L}^{1}$ moiety are modified to some degree upon coordination; the biggest change impacts $\mathrm{N}(15) \mathrm{py}-\mathrm{C}(13)-\mathrm{C}(9), \mathrm{C}(5)-$ $\mathrm{N}(4)$ py-C(3), $\mathrm{C}(7)-\mathrm{C}(3)-\mathrm{N}(4)$ py, $\mathrm{C}(9)-\mathrm{N}(8)$ triaz-C(7), N(12)triaz-C(7)-C(3) and $\mathrm{C}(13)-\mathrm{C}(9)-\mathrm{N}(8)$ triaz which are lessened or expanded on complex formation as a result of bonding.

5) $\mathbf{L}^{1}$ in $\left[\mathrm{VO}\left(\mathbf{L}^{1}\right) \mathrm{SO}_{4}\left(\mathrm{H}_{2} \mathrm{O}\right)_{3 / 2}\right] \cdot 2.5 \mathrm{H}_{2} \mathrm{O}$ (Figure S31), acts as a tridentate style coordinating by mean of $\mathrm{N}(5)$ triaz, $\mathrm{N}(19)$ py and $\mathrm{N}(20)$ py atoms. The ions $\mathrm{O}(26)$ in axial positions and $\mathrm{O}(27)$ finish the square-pyramidal structure. There is a vast varietyin $\mathrm{C}(18)-\mathrm{N}(19) \mathrm{py}, \mathrm{C}(21)-\mathrm{C}(22), \mathrm{N}(20)$ py- $\mathrm{C}(21), \mathrm{N}(19)$ py-C(8), $\mathrm{C}(6)-\mathrm{C}(7)$, $\mathrm{N}(5)$ triaz-C(6), $\mathrm{C}(4)-\mathrm{C}(8), \mathrm{C}(7)-\mathrm{N}(20)$ py and $\mathrm{C}(4)-\mathrm{N}(5)$ triaz bond lengths. The bond angles of the $\mathbf{L}^{1}$ moiety are modified to some degree upon coordination; the biggest change influences $\mathrm{C}(21)-\mathrm{N}(20) \mathrm{py}-\mathrm{C}(7)$, C(18)-N(19)py-C(8), N(19)py-C(8)-C(4), N(20)py-C(7)-C(6), C(7)-C(6)-N(5)triaz, C(6)-N(5)triaz-C(4) and $\mathrm{C}(8)-\mathrm{C}(4)-\mathrm{N}(5)$ triaz which are lessened or expanded on complex formation as a result of bonding.

6) $\left[\mathrm{V}_{2} \mathrm{O}_{2}\left(\mathbf{L}^{1}\right)\left(\mathrm{SO}_{4}\right)_{2}\left(\mathrm{H}_{2} \mathrm{O}\right)\right] \cdot \mathrm{H}_{2} \mathrm{O}$ (Figure $\left.\mathrm{S} 32\right)$ has a square-pyramidal structure. $\mathbf{L}^{\mathbf{1}}$ acts as a tridentate manner coordinating via $\mathrm{N}(5)$ triaz, $\mathrm{N}(10)$ py and $\mathrm{N}(19)$ py atoms, also coordinates as a bidentate style coordinating via $\mathrm{N}(1)$ triaz and $\mathrm{N}(20)$ py atoms. In case of the tridentate fashion the atoms $\mathrm{O}(31)$ and $\mathrm{O}(26)$ finish the square-pyramidal structure and dwell, while in case of a bidentate fashion the atoms $\mathrm{O}(33), \mathrm{O}(35)$ of sulphate group and $\mathrm{O}(34)$ of water molecule finish the square-pyramidal structure. There is a vast varietyin $\mathrm{N}(20)$ py-C(21), $\mathrm{C}(18)-$ N(19)py, N(10)py-C(11), C(9)-N(20)py, N(19)py-C(8), C(7)-N(10)py, C(6)-C(7), N(5)triaz-C(6), C(4)-C(8), $\mathrm{C}(4)-\mathrm{N}(5)$ triaz, $\mathrm{C}(2)-\mathrm{C}(9), \mathrm{C}(6)-\mathrm{N}(1)$ triaz and $\mathrm{N}(1)$ triaz- $\mathrm{C}(2)$ bond lengths. The bond angles in $\left[\mathrm{V}_{2} \mathrm{O}_{2}(\mathrm{TPTZ})\right.$ $\left.\left(\mathrm{SO}_{4}\right)_{2}\left(\mathrm{H}_{2} \mathrm{O}\right)\right] \cdot \mathrm{H}_{2} \mathrm{O}$ complex are very close tosquare-pyramidal geometry where the bond angles of atoms around the $\mathrm{V}^{4+}$ atoms in the square-pyramidal structure are $\mathrm{N}(20)$ py- $\mathrm{V}(32)-\mathrm{N}(1)$ triaz, $\mathrm{N}(19)$ py- $\mathrm{V}(25)-\mathrm{N}(10) \mathrm{py}$, N(19)py-V(25)-N(5)triaz， N(10)py-V(25)-N(5)triaz，C(21)-N(20)py-C(9)，C(18)-N(19)py-C(8)， C(11)-N(10) py-C(7), N(20)py-C(9)-C(2), N(19)py-C(8)-C(4), N(10)py-C(7)-C(6), C(7)-C(6)-N(5)triaz, C(6)-N(5)triaz-C(4), $\mathrm{C}(8)-\mathrm{C}(4)-\mathrm{N}(5)$ triaz, $\mathrm{C}(9)-\mathrm{C}(2)-\mathrm{N}(1)$ triaz and $\mathrm{C}(6)-\mathrm{N}(1)$ triaz-C(2). The bond angles of the TPTZ moiety are modified somewhat upon coordination; the largest change influences $\mathrm{C}(11)-\mathrm{N}(10) \mathrm{py}-\mathrm{C}(7), \mathrm{C}(6)-\mathrm{N}(5)$ triaz-C(4), $\mathrm{C}(8)-\mathrm{C}(4)-\mathrm{N}(5)$ triaz, C(9)-C(2)-N(1)triaz, N(20)py-C(9)-C(2), which are decreased or increased on complex formation as a result of bonding.

\subsubsection{Chemical Reactivity}

\section{Global Reactivity Descriptors}

The determination of energies of the HOMO ( $\pi$-donor) and LUMO ( $\pi$-acceptor) are essential parameters in quantum chemical computations. The HOMO is the orbital that fundamentally goes about as an electron donor and the LUMO is the orbital that largely to a great extent go about as the electron acceptor. These molecular orbitals are additionally called the frontier molecular orbitals (FMOs).

i) The $\mathrm{E}_{\text {Hомо }}$ and $\mathrm{E}_{\mathrm{LUMO}}$ and their neighboring orbitals are all negative (Table 3), which appear that the investigated molecules are steady [41].

Table 3. Calculated $\mathrm{E}_{\text {Hомо }}, \mathrm{E}_{\mathrm{Lumo}}$, energy band gap $\left(\mathrm{E}_{\mathrm{H}}-\mathrm{E}_{\mathrm{L}}\right)$, chemical potential $(\mu)$, electronegativity $(\chi)$, global hardness $(\eta)$, global softness $(S)$ and global electrophilicity index $(\omega)$ for $\mathbf{L}^{\mathbf{1}}$ and its complexes.

\begin{tabular}{cccccccccc}
\hline Compound & $\mathbf{E}_{\mathbf{H}} \mathbf{e V}$ & $\mathbf{E L ~ e V}$ & $\left(\mathbf{E}_{\mathbf{H}}-\mathbf{E}_{\mathbf{L}}\right) \mathbf{e V}$ & $\boldsymbol{X} \mathbf{e V}$ & $\boldsymbol{\mu} \mathbf{e V}$ & $\boldsymbol{\eta} \mathbf{e V}$ & $\boldsymbol{S ~ e V}^{-1}$ & $\boldsymbol{\omega} \mathbf{e V}$ & $\boldsymbol{\sigma} \mathbf{e V}$ \\
\hline $\mathbf{L}^{1}$ & -3.814 & -2.479 & -1.335 & 3.1465 & -3.1465 & 0.6675 & 0.749064 & 7.416077 & 1.498127 \\
{$\left[\mathrm{~V}_{3} \mathrm{O}_{3}\left(\mathbf{L}^{1}\right)\left(\mathrm{SO}_{4}\right)_{3}(\mathrm{EtOH})_{1 / 2}\left(\mathrm{H}_{2} \mathrm{O}\right)_{3 / 2}\right]$} & -5.897 & -5.875 & -0.022 & 5.886 & -5.886 & 0.011 & 45.45455 & 1574.773 & 90.90909 \\
{$\left[\mathrm{VO}\left(\mathbf{L}^{1}\right)(2,4-\mathrm{pentadionate})\right] \mathrm{Cl} \cdot 4 \mathrm{HCl}$} & -6.027 & -3.614 & -2.413 & 4.8205 & -4.8205 & 1.2065 & 0.414422 & 9.630013 & 0.828844 \\
{$\left[\mathrm{~V}_{2} \mathrm{O}_{2}\left(\mathbf{L}^{1}\right)\left(\mathrm{SO}_{4}\right)_{2}(\mathrm{EtOH})_{5 / 2}\right]$} & -6.579 & -4.08 & -2.499 & 5.3295 & -5.3295 & 1.2495 & 0.40016 & 11.36597 & 0.80032 \\
{$\left[\mathrm{~V}_{2} \mathrm{O}_{2}\left(\mathbf{L}^{1}\right)\left(\mathrm{SO}_{4}\right)_{2}(\mathrm{EtOH})_{3 / 2}\left(\mathrm{H}_{2} \mathrm{O}\right)_{1 / 2}\right]$} & -5.248 & -4.758 & -0.49 & 5.003 & -5.003 & 0.245 & 2.040816 & 51.08165 & 4.081633 \\
{$\left[\mathrm{VO}\left(\mathbf{L}^{1}\right) \mathrm{SO}_{4}\left(\mathrm{H}_{2} \mathrm{O}\right)_{3 / 2}\right] \cdot 2.5 \mathrm{H}_{2} \mathrm{O}$} & -4.373 & -4.297 & -0.076 & 4.335 & -4.335 & 0.038 & 13.15789 & 247.2661 & 26.31579 \\
{$\left[\mathrm{~V}_{2} \mathrm{O}_{2}\left(\mathbf{L}^{1}\right)\left(\mathrm{SO}_{4}\right)_{2}\left(\mathrm{H}_{2} \mathrm{O}\right)\right] \cdot \mathrm{H}_{2} \mathrm{O}$} & -5.053 & -5.041 & -0.012 & 5.047 & -5.047 & 0.006 & 83.33333 & 2122.684 & 166.6667 \\
\hline
\end{tabular}

$\mathrm{H}=\mathrm{HOMO}, \mathrm{L}=\mathrm{LUMO}$. 
ii) The FMOs theory predicts positions of coordination (electrophilic attack) on aromatic compounds. An introductory assumption is that the reaction happens with most extreme overlap between the HOMO on one molecule and the LUMO on the other. The overlap between the HOMO and the LUMO is a governing factor in many reactions. The aim of the calculations is the scanning for the biggest estimations of molecular orbital coefficients. In this way, orbitals of $\mathbf{L}^{1}$ with the biggest estimation of molecular orbital coefficients may be considered as the locales of coordination. This conclusion is affirmed by the data acquired from the calculations which can demonstrate that the nitrogen of the CN group has the largest values of molecular orbital coefficients.

iii) Gutmann's variation rules, "the bond strength increases as the adjacent bonds become weaker" such as found by Linert et al. [42]. This elucidation concurs well with the resultant as the increment of the $\mathrm{E}_{\text {номо }}$ is joined by a shortcoming (lengthening) of the metal-ligand bonds, which prompts a reinforcing (shortness) of the destinations nearby the metal ligand centers.

iv) The HOMO level is for the most part confined on the Natom (Figure 8 and Figure S27-S31) indicating that this atom is the favored nucleophile positions at the central metal ion. This implies that these moieties, with high coefficients of HOMO density, are oriented toward the metal ions.

v) The energy gap ( $\left.\mathrm{E}_{\mathrm{HOMO}}-\mathrm{E}_{\mathrm{LUMO}}\right)$ is a critical stability index serves to investigate the chemical reactivity and kinetic stability of the molecule [43]. The gap $\left(\mathrm{E}_{\text {номо }}-\mathrm{E}_{\mathrm{LUMO}}\right)$ is applied to improve a theoretical model for clarifying the structure and conformation barriers in many molecular systems, which impacts the biological activity of the molecule. A molecule with a little gap is more polarized and is called soft molecule. Soft molecules are more reactive than hard ones due to their easily offer electrons to an acceptor. The energy gap is little in $\mathbf{L}^{1}$ estimating that charge-transfer easily happen in it, which impacts the biological activity of the molecule. Low value of energy gap is additionally referred to the groups that go into conjugation [44].

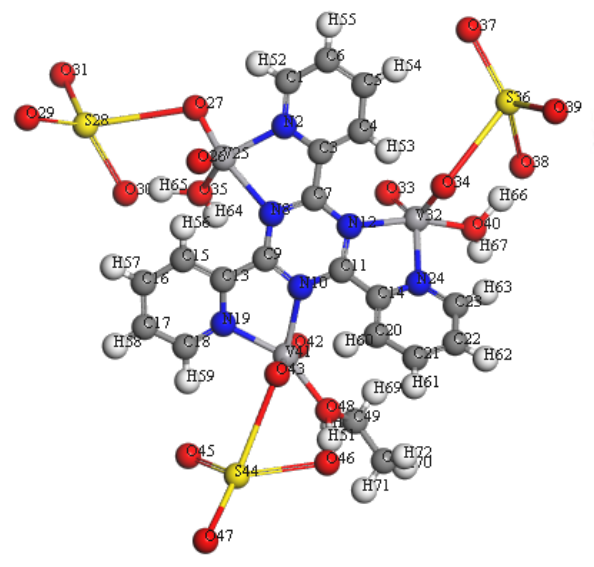

(a)

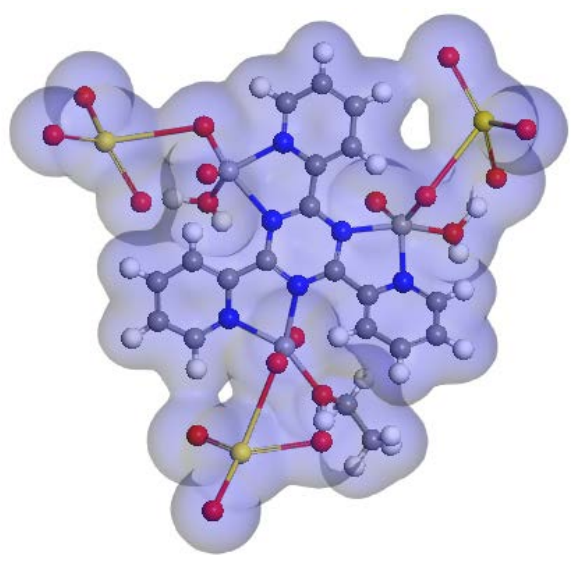

(b)

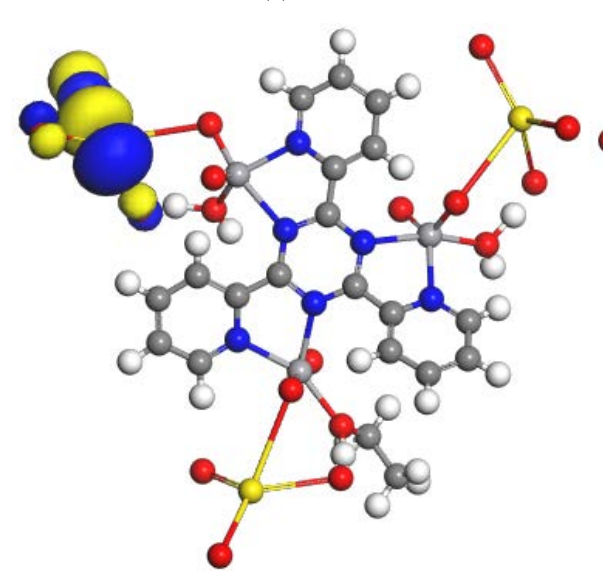

(c)

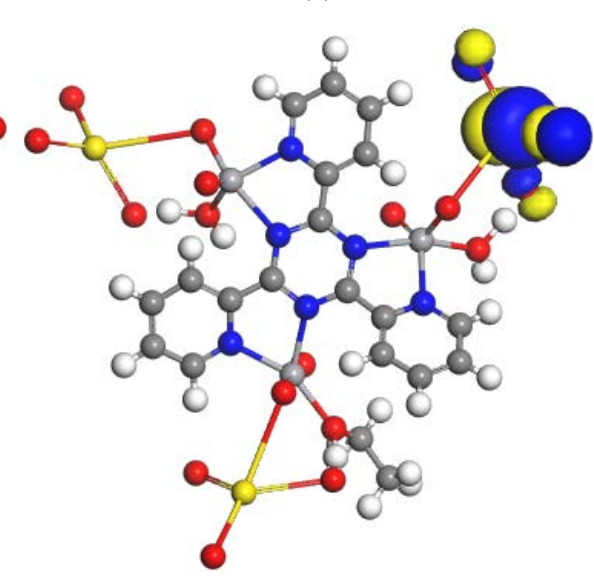

(d)

Figure 8. Molecular modeling of $(a)\left[\mathrm{V}_{3} \mathrm{O}_{3}\left(\mathrm{~L}^{1}\right)\left(\mathrm{SO}_{4}\right)_{3}(\mathrm{EtOH})_{1 / 2}\left(\mathrm{H}_{2} \mathrm{O}\right)_{3 / 2}\right]$, (b) electron density, (c) HOMO and (d) LUMO. 
vi) The lower HOMO energy estimations demonstrate that molecules donating electron ability is the weaker. On opposite, the higher HOMO energy suggests that the molecule is a good electron donor. LUMO energy displays s the ability of a molecule receiving electron [43].

DFT method concept can suggest the chemical reactivity and position selectivity of the molecular systems. The energies of frontier molecular orbitals $\left(E_{\text {номо }}+E_{\text {LUмо }}\right.$ ), energy band gap ( $\left.E_{\text {номо }}-E_{\text {LUмо }}\right)$ which shows the eventual charge-transfer interaction within the molecule, electronegativity $(\chi)$, chemical potential $(\mu)$, global hardness $(\eta)$, global softness $(S)$ and global electrophilicity index $(\omega)$ [45]-[46] are appeared in Table 3.

$$
\begin{gathered}
\chi=-1 / 2\left(\mathrm{E}_{\text {LUмо }}+\mathrm{E}_{\text {номо }}\right) \\
\mu=-\chi=1 / 2\left(\mathrm{E}_{\text {LUмо }}+\mathrm{E}_{\text {номо }}\right) \\
\eta=1 / 2\left(\mathrm{E}_{\text {LUмо }}-\mathrm{E}_{\text {номо }}\right) \\
S=1 / 2 \eta \\
\omega=\mu^{2} / 2 \eta
\end{gathered}
$$

The inverse value of the global hardness is designed as the softness $\sigma$ as follow:

$$
\sigma=1 / \eta
$$

Electrophilicity index is one of the most vital quantum chemical descriptors in explaining toxicity of different pollutants in terms of their reactivity and position selectivity [47]. Also, the electrophilicity properly quantifies the biological activity of drug receptor collaboration. This novel reactivity index calculates the stabilization in energy when the system acquires an extra electronic charge from the environment. So, the importance of $\eta$ and $\sigma$ is to calculate the molecular stability and reactivity. In a complex formation system, $\mathbf{L}^{1}$ serves as a Lewis base while the $\mathrm{V}^{4+}$ acts as a Lewis acid.

\subsubsection{Molecular Electrostatic Potential (MEP)}

The MEP is a plot of electrostatic potential mapped onto the steady electron density surface. It is additionally exceptionally helpful in exploration of molecular structure with its physiochemical property relationship and also hydrogen bonding interactions [48]-[50]. The electrostatic potential $\mathrm{V}(r)$ at a given point $r(x, y, z)$ is the interaction energy between the electrical charge produced from the molecule electrons, nuclei and proton located at $r$ [51] [52]. In the present study, 3D plots of molecular electrostatic potential (MEP) of $\mathbf{L}^{1}$ (Figure 9) have been drew. The maximum negative, region which favored local for electrophilic attack, is shown by a red color, the maximum positive region which favored position for nucleophilic attack indicated as blue color. Potential

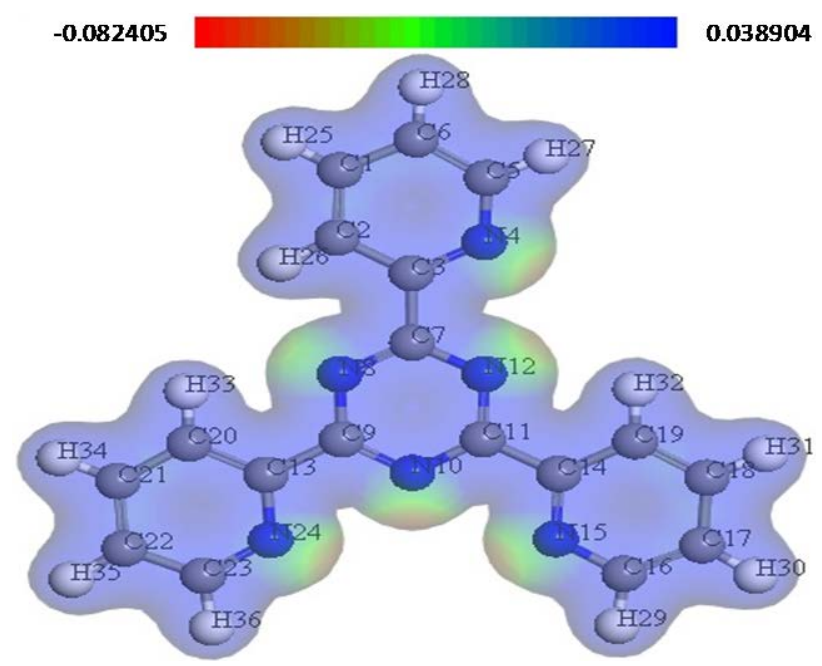

Figure 9. MEP plot by using DFT method forL ${ }^{1}$. 
increases in the order red $<$ green $<$ blue, where blue represents the strongest attraction and red reveals the strongest repulsion. Regions having the negative potential are over the electronegative atoms while the regions having the positive potential are over the hydrogen atoms.

\subsubsection{Dipole Moment and other Molecular Properties}

The calculations of the binding energy uncovered that the increment of the value of the calculated binding energy of $\mathrm{V}^{4+}$ complexes contrasted with $\mathbf{L}^{1}$ indicates that the formed $\mathrm{V}^{4+}$ complexes are more stable than $\mathbf{L}^{1}$. Also, energy components were evaluated by DFT method listed in Table 4.

\subsection{Biological Activity}

\subsubsection{Antibacterial Activity}

Depending on data obtained for diameter of inhibition zone (Figure 10 and Table 5), it was found that the complexes were active on both sorts of bacterial strains. A look of data shows that:

i) $\left[\mathrm{V}_{3} \mathrm{O}_{3}\left(\mathbf{L}^{\mathbf{1}}\right)\left(\mathrm{SO}_{4}\right)_{3}(\mathrm{EtOH})_{1 / 2}\left(\mathrm{H}_{2} \mathrm{O}\right)_{3 / 2}\right]$, [VO( $\left.\mathbf{L}^{\mathbf{1}}\right)(2,4$-pentadionate $\left.)\right] \mathrm{Cl} \cdot 4 \mathrm{HCl},\left[\mathrm{V}_{2} \mathrm{O}_{2}\left(\mathbf{L}^{\mathbf{1}}\right)\left(\mathrm{SO}_{4}\right)_{2}(\mathrm{EtOH})_{3 / 2}\left(\mathrm{H}_{2} \mathrm{O}\right)_{1 / 2}\right]$ and $\left[\mathrm{V}_{2} \mathrm{O}_{2}\left(\mathbf{L}^{1}\right)\left(\mathrm{SO}_{4}\right)_{2}\left(\mathrm{H}_{2} \mathrm{O}\right)\right] \cdot \mathrm{H}_{2} \mathrm{O}$ complexes exhibited aexceptional antibacterial activity against all organisms.

ii) $\left[\mathrm{VO}\left(\mathbf{L}^{1}\right)(2,4\right.$-pentadionate) $] \mathrm{Cl} \cdot 4 \mathrm{HCl}$ revealed a potent antibacterial activity against Escherichia coli and Candida albicans bacterial strain (Gram-ve) more than $\left[\mathrm{V}_{3} \mathrm{O}_{3}\left(\mathbf{L}^{1}\right)\left(\mathrm{SO}_{4}\right)_{3}(\mathrm{EtOH})_{1 / 2}\left(\mathrm{H}_{2} \mathrm{O}\right)_{3 / 2}\right]$ then $\left[\mathrm{V}_{2} \mathrm{O}_{2}\left(\mathbf{L}^{1}\right)\right.$ $\left.\left(\mathrm{SO}_{4}\right)_{2}\left(\mathrm{H}_{2} \mathrm{O}\right)\right] \cdot \mathrm{H}_{2} \mathrm{O}$ and $\left[\mathrm{V}_{2} \mathrm{O}_{2}\left(\mathbf{L}^{1}\right)\left(\mathrm{SO}_{4}\right)_{2}(\mathrm{EtOH})_{3 / 2}\left(\mathrm{H}_{2} \mathrm{O}\right)_{1 / 2}\right]$.

iii) $\left[\mathrm{V}_{3} \mathrm{O}_{3}\left(\mathbf{L}^{1}\right)\left(\mathrm{SO}_{4}\right)_{3}(\mathrm{EtOH})_{1 / 2}\left(\mathrm{H}_{2} \mathrm{O}\right)_{3 / 2}\right]$ had a potent antibacterial activity against Staphylococcus aureus bacterial strain (Gram + ve) more than $\left[\mathrm{VO}\left(\mathbf{L}^{1}\right)(2,4\right.$-pentadionate) $] \mathrm{Cl} \cdot 4 \mathrm{HCl}$ and $\left[\mathrm{V}_{2} \mathrm{O}_{2}\left(\mathbf{L}^{1}\right)\left(\mathrm{SO}_{4}\right)_{2}(\mathrm{EtOH})_{3 / 2}\left(\mathrm{H}_{2} \mathrm{O}\right)_{1 / 2}\right]$ and $\left[\mathrm{V}_{2} \mathrm{O}_{2}\left(\mathbf{L}^{1}\right)\left(\mathrm{SO}_{4}\right)_{2}\left(\mathrm{H}_{2} \mathrm{O}\right)\right] \cdot \mathrm{H}_{2} \mathrm{O}$ have the lower and equal an anti-bacterial activity.

The outcomes can be can be ascribed either to the failure of the complexes to diffuse through the cell wall of

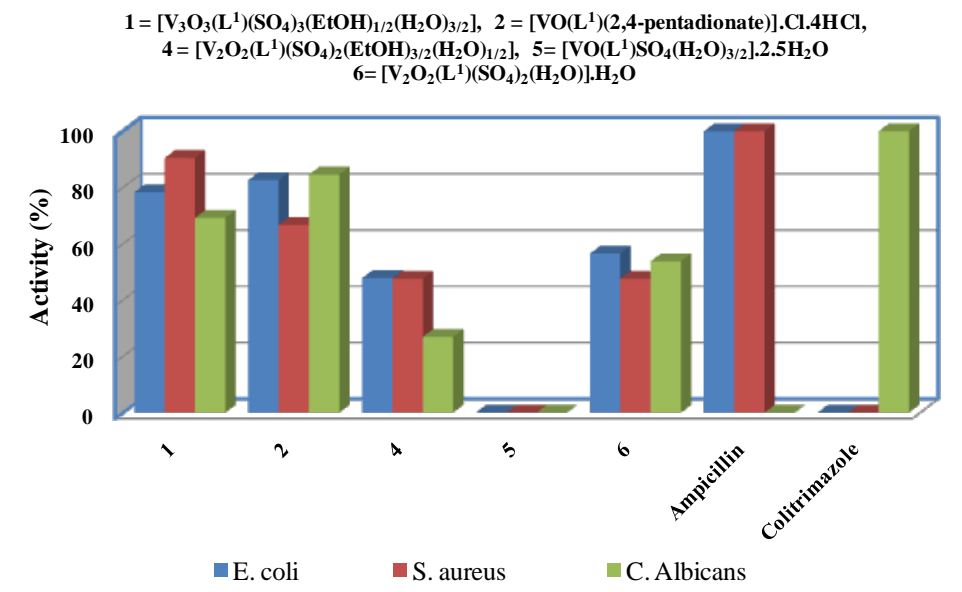

Figure 10. Antimicrobial activity of $\mathrm{V}^{4+}$-complexes.

Table 4. Some of energetic properties of $\mathrm{L}^{1}$ and complexes calculated by DMOL ${ }^{3}$ using DFT-method.

\begin{tabular}{ccccccc}
\hline No. & Compound & HOMO $(\mathrm{eV})$ & LUMO $(\mathrm{eV})$ & $\begin{array}{c}\text { Binding energy } \\
(\mathrm{Kcal} / \mathrm{mol})\end{array}$ & $\begin{array}{c}\text { Total energy } \\
(\mathrm{Kcal} / \mathrm{mol})\end{array}$ & Dipole moment (D) \\
\hline $\mathbf{1}$ & $\mathbf{L}^{1} \mathrm{C}_{18} \mathrm{H}_{12} \mathrm{~N}_{6}$ & -3.814 & -2.479 & -4430.410 & $-6.413 \times 10^{5}$ & 3.2814 \\
$\mathbf{2}$ & {$\left[\mathrm{V}_{3} \mathrm{O}_{3}\left(\mathbf{L}^{1}\right)\left(\mathrm{SO}_{4}\right)_{3}(\mathrm{EtOH})_{1 / 2}\left(\mathrm{H}_{2} \mathrm{O}\right)_{3 / 2}\right]$} & -5.897 & -5.875 & -8363.258 & $-2.455 \times 10^{6}$ & 11.1456 \\
$\mathbf{3}$ & {$\left[\mathrm{VO}\left(\mathbf{L}^{\mathbf{1}}\right)(2,4-\mathrm{pentadionate)})\right] \mathrm{Cl} \cdot 4 \mathrm{HCl}$} & -6.027 & -3.614 & -6297.314 & $-9.60 \times 10^{5}$ & 4.3354 \\
$\mathbf{4}$ & {$\left[\mathrm{V}_{2} \mathrm{O}_{2}\left(\mathbf{L}^{\mathbf{1}}\right)\left(\mathrm{SO}_{4}\right)_{2}(\mathrm{EtOH})_{5 / 2}\right]$} & -6.579 & -4.080 & -8174.541 & $-1.917 \times 10^{6}$ & 12.2852 \\
$\mathbf{5}$ & {$\left[\mathrm{V}_{2} \mathrm{O}_{2}\left(\mathbf{L}^{\mathbf{1}}\right)\left(\mathrm{SO}_{4}\right)_{2}(\mathrm{EtOH})_{3 / 2}\left(\mathrm{H}_{2} \mathrm{O}\right)_{1 / 2}\right]$} & -5.248 & -4.758 & -7179.095 & $-1.867 \times 10^{6}$ & 14.278 \\
$\mathbf{6}$ & {$\left[\mathrm{VO}\left(\mathbf{L}^{\mathbf{1}}\right) \mathrm{SO}_{4}\left(\mathrm{H}_{2} \mathrm{O}\right)_{3 / 2}\right] \cdot 2.5 \mathrm{H}_{2} \mathrm{O}$} & -4.373 & -4.297 & -5679.432 & $-1.277 \times 10^{6}$ & 10.7288 \\
$\mathbf{7}$ & {$\left[\mathrm{V}_{2} \mathrm{O}_{2}\left(\mathbf{L}^{1}\right)\left(\mathrm{SO}_{4}\right)_{2}\left(\mathrm{H}_{2} \mathrm{O}\right)\right] \cdot \mathrm{H}_{2} \mathrm{O}$} & -5.053 & -5.041 & -5664.384 & $-1.769 \times 10^{6}$ & 9.4451 \\
\hline
\end{tabular}


Table 5. Antimicrobial activities of the isolated complexes.

\begin{tabular}{|c|c|c|c|c|c|c|c|}
\hline \multirow[b]{2}{*}{ No. } & \multirow[b]{2}{*}{ Compound } & \multicolumn{2}{|l|}{ E. coli $(\mathrm{mg} / \mathrm{ml})$} & \multicolumn{2}{|c|}{ S. aureus (mg/ml) } & \multicolumn{2}{|c|}{ C. Albicans (mg/ml) } \\
\hline & & $\begin{array}{c}\text { Diameter of } \\
\text { inhibition zone (in } \mathrm{mm} \text { ) }\end{array}$ & $\begin{array}{l}\text { \% Activity } \\
\text { index }\end{array}$ & 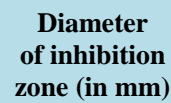 & $\begin{array}{l}\% \text { Activi- } \\
\text { ty index }\end{array}$ & $\begin{array}{c}\text { Diameter } \\
\text { of inhibition } \\
\text { zone (in } \mathbf{~ m m )}\end{array}$ & $\begin{array}{l}\text { \% Activity } \\
\text { index }\end{array}$ \\
\hline 1 & {$\left[\mathrm{~V}_{3} \mathrm{O}_{3}\left(\mathbf{L}^{1}\right)\left(\mathrm{SO}_{4}\right)_{3}(\mathrm{EtOH})_{1 / 2}\left(\mathrm{H}_{2} \mathrm{O}\right)_{3 / 2}\right]$} & 18 & 78.3 & 19 & 90.5 & 18 & 69.2 \\
\hline 2 & {$\left[\mathrm{VO}\left(\mathbf{L}^{1}\right)(2,4\right.$-pentadionate $\left.)\right] \mathrm{Cl} \cdot 4 \mathrm{HCl}$} & 19 & 82.6 & 14 & 66.7 & 22 & 84.6 \\
\hline 4 & {$\left[\mathrm{~V}_{2} \mathrm{O}_{2}\left(\mathbf{L}^{\mathbf{1}}\right)\left(\mathrm{SO}_{4}\right)_{2}(\mathrm{EtOH})_{3 / 2}\left(\mathrm{H}_{2} \mathrm{O}\right)_{1 / 2}\right]$} & 11 & 47.8 & 10 & 47.6 & 7 & 26.9 \\
\hline 5 & {$\left[\mathrm{VO}\left(\mathbf{L}^{1}\right) \mathrm{SO}_{4}\left(\mathrm{H}_{2} \mathrm{O}\right)_{3 / 2}\right] \cdot 2.5 \mathrm{H}_{2} \mathrm{O}$} & - & NA & - & NA & - & NA \\
\hline 6 & {$\left[\mathrm{~V}_{2} \mathrm{O}_{2}\left(\mathbf{L}^{1}\right)\left(\mathrm{SO}_{4}\right)_{2}\left(\mathrm{H}_{2} \mathrm{O}\right)\right] \cdot \mathrm{H}_{2} \mathrm{O}$} & 13 & 56.5 & 10 & 47.6 & 14 & 53.8 \\
\hline & Ampicillin & 23 & 100 & 21 & 100 & - & NA \\
\hline & Colitrimazole & - & NA & - & NA & 26 & 100 \\
\hline
\end{tabular}

the bacterium and henceforth not able to meddle with its biological activity or they can diffuse and inactivated by unknown cellular mechanism i.e. bacterial enzymes. The reason for high antimicrobial activity of vanadium complexes can be clarified regarding the impact of vanadium metal ion on the normal cell process. The complexation reaction decreases the polarity of the metal ion by the partial participating of metal ion positive charge with donor groups and electron delocalization over the chelate ring. Hence, the lipophilic character of the central metal atom is improved which brings about a higher capacity to penetrate the microorganisms through the lipid layer of the cell membrane. In addition, all metal complexes under the investigation estimate a large value of binding energy than $\mathbf{L}^{\mathbf{1}}$ that enhances the steadiness of these complexes [53]. Additionally, electrophilicity of all complexes is bigger than that of $\mathbf{L}^{1}$ and that could be another target behind some complexes to exhibit the biggest strong antimicrobial activity than the ligand. Likewise, it is observed from these studies that the vast majority of the metal chelates have a higher movement than the free ligand and that can be explained on the premise of chelation hypothesis. The chelation goes about as all the more able and strong fungicidal and bactericidal agents, subsequently murdering more fungi and bacteria than the ligand. In the complex the positive charge of the metal is somewhat imparted to the donor atoms present in the ligands, and there may be $\pi$-electron delocalization over the all chelating system [54]. The variety in the activity of different complexes against various microorganisms depend either on cells impermeability of the microbes or contrasts in ribosomes in microbial cells [55]. The negative results can be credited either to the powerlessness of the complexes to diffuse through the cell wall of the bacterium and henceforth not able to interfere with its biological activity or they can diffuse and inactivated by obscure cellular mechanism i.e. bacterial enzymes.

\subsubsection{In Vitro Anticancer Activity}

In vitro cytotoxicity tests were conducted utilizing all the prepared compounds against human tumor cell lines MCF-7 and Hela normal cell line by means of a colorimetric assay (MTT assay) that is a measurement for mitochondrial dehydrogenase activity as an indication of cell viability. The activities corresponding to viability of cancer cell growth. In parallel, the impact of widely utilized anticancer drug, 5-fluorouracil has been also assayed as standard. The $\mathrm{IC}_{50}$ values were computed from the graph plotted between $\%$ cell viability and concentration. The outcomes of IC $_{50}$ of five complexes for both cell lines covered a large range of activity with ranging from 5.7 to $50.4 \mu \mathrm{g} / \mathrm{ml}$ as appeared in Figure 11, indicating that the five complexes exhibited antitumor activity against the cell lines without damaging the normal cells. $\left[\mathrm{VO}\left(\mathbf{L}^{\mathbf{1}}\right) \mathrm{SO}_{4}\left(\mathrm{H}_{2} \mathrm{O}\right)_{3 / 2}\right] \cdot 2.5 \mathrm{H}_{2} \mathrm{O}$ and $\left[\mathrm{VO}\left(\mathbf{L}^{\mathbf{1}}\right)(2,4\right.$-pentadionate) $\mathrm{Cl} \cdot 4 \mathrm{HCl}$ complexes revealed potential activity than $\left[\mathrm{V}_{3} \mathrm{O}_{3}\left(\mathbf{L}^{1}\right)\left(\mathrm{SO}_{4}\right)_{3}(\mathrm{EtOH})_{1 / 2}\left(\mathrm{H}_{2} \mathrm{O}\right)_{3 / 2}\right]$ complex than $\left[\mathrm{V}_{2} \mathrm{O}_{2}\left(\mathbf{L}^{1}\right)\left(\mathrm{SO}_{4}\right)_{2}\left(\mathrm{H}_{2} \mathrm{O}\right)\right] \cdot \mathrm{H}_{2} \mathrm{O}$ then $\left[\mathrm{V}_{2} \mathrm{O}_{2}\left(\mathbf{L}^{\mathbf{1}}\right)\left(\mathrm{SO}_{4}\right)_{2}(\mathrm{EtOH})_{3 / 2}\left(\mathrm{H}_{2} \mathrm{O}\right)_{1 / 2}\right]$, respectively. It means that the chemical structure of compounds is important to explain the complex biological activity and it can be essential in designing and synthesizing novel anticancer drugs. There is obviously direct correlation between strong interaction of V(IV) complex with DNA and antiproliferative activity of V(IV) complex. These observations suggests that DNA may be the targeting molecules of V(IV) complex's anti-carcinogenic action, and V(IV) ion coordination and bind significantly enhances the Schiff base drugs anticancer activity. So, It is unmistakably watched that complexation with metal has a synergistic impact on the cytotoxicity. 


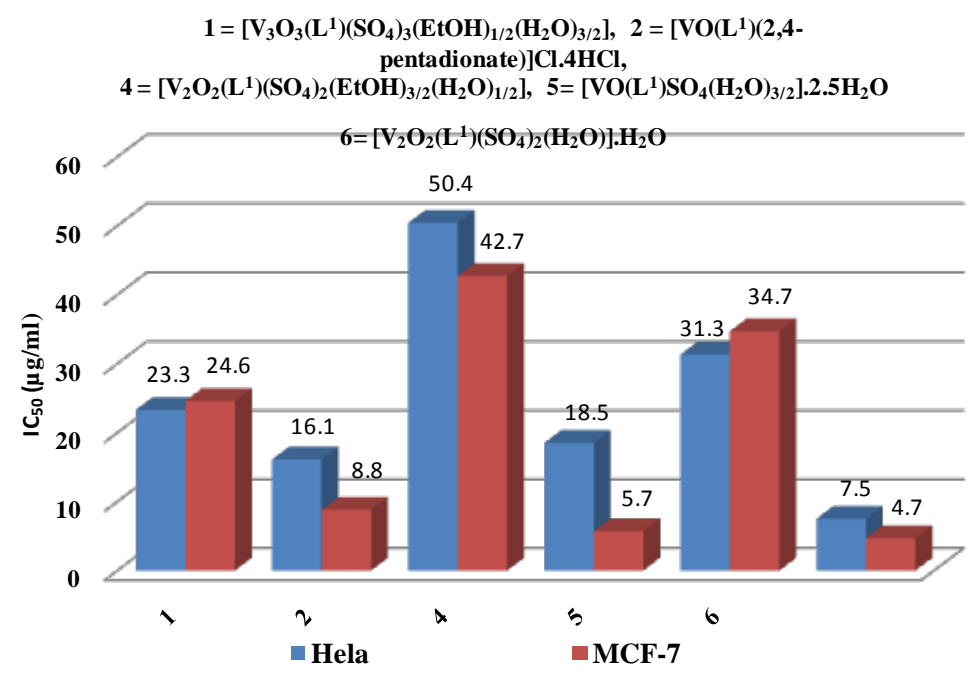

Figure 11. Scavenging capacities (IC50) of $\mathrm{V}^{4+}$ complexes (5-fluorouracilstandardantitumor).

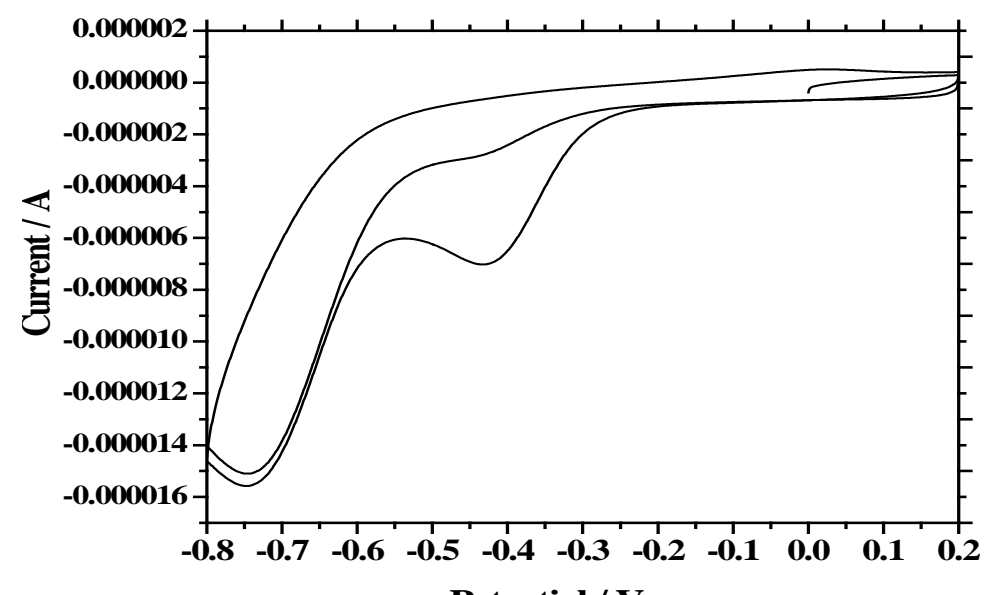

Potential / V

Figure 12. Cyclic voltammogram in DMSO solution with $0.1 \mathrm{M}$ tetrabutylammonium perchlorate (TBAP), scan rate $50 \mathrm{mVs}^{-1}$ for $10^{-3} \mathrm{M}$ of $\left[\mathrm{V}^{\mathrm{IV}} \mathrm{O}\right.$ $\left(\mathrm{L}^{1}\right)(2,4$-pentadionate) $\mathrm{Cl} \cdot 4 \mathrm{HCl}$.

\subsection{Voltammetric Studies}

The voltammogram reveals two reduction peaks for the complex $\left[\mathrm{V}^{\mathrm{IV}} \mathrm{O}\left(\mathbf{L}^{\mathbf{1}}\right)(2,4\right.$-pentadionate) $] \mathrm{Cl} \cdot 4 \mathrm{HCl}$, centered at $-0.75 \mathrm{~V}$ and $-0.43 \mathrm{~V}$ which correspond to $\mathrm{V}^{\mathrm{IV}} / \mathrm{V}^{\mathrm{II}}$ and $\mathrm{V}^{\mathrm{IV}} / \mathrm{V}^{\mathrm{III}}$, respectively as appeared in (Figure 12) [56].

\section{References}

[1] Tsiani, E. and Fantus, I.G. (1997) Vanadium Compounds Biological Actions and Potential as Pharmacological Agents. Trends in Endocrinology \& Metabolism, 8, 51-58. http://dx.doi.org/10.1016/S1043-2760(96)00262-7

[2] Goldwaser, I., Gefel, D., Gershonov, E., Fridkin, M. and Shechter, Y. (2000) Insulin-Like Efects of Vanadium: Basic and Clinical Implications. Journal of Inorganic Biochemistry, 80, 21-25. http://dx.doi.org/10.1016/S0162-0134(00)00035-0

[3] Thompson, H.J., Chasteen, N.D. and Meeker, L.D. (1984) Dietary Vanadyl (IV) Sulfate Inhibits Chemically-Induced Mammary Carcinogenesis. Carcinogenesis, 5, 849-851. http://dx.doi.org/10.1093/carcin/5.6.849

[4] Rizk, S.L. and Sky-Peck, H.H. (1984) Comparison between Concentrations of Trace Elements in Normal and Neoplastic Human Breast Tissue. Cancer Research, 44, 5390-5394. 
[5] De Silva, C.R., Wang, R. and Zheng, Z. (2006) Highly Luminescent Eu (III) Complexes with 2,4,6-Tri(2-pyridyl)1,3,5-triazine Ligand: Synthesis, Structural Characterization, and Photo-Luminescence Studies. Polyhedron, 25, 34493455. http://dx.doi.org/10.1016/j.poly.2006.06.032

[6] Paul, P. (2002) Ruthenium, Osmium and Rhodium Complexes of Polypyridyl Ligands: Metal-Promoted Activities, Stereochemical Aspects and Electrochemical Properties. Proceedings of the Indian Academy of Sciences, 114, 269276. http://dx.doi.org/10.1007/BF02703819

[7] Pruchnik, F.P., Jakimowicz, P., Ciunik, Z., Czerwinska, J.Z., Opolski, A., Wietrzyk, J. and Wojdat, E. (2002) Rhodium (III) Complexes with Polypyridyls and Pyrazole and Their Antitumor Activity. Inorganica Chimica Acta, 334, 59-66. http://dx.doi.org/10.1016/S0020-1693(02)00776-4

[8] Najafpour, M.M., Holynska, M., Amini, M., Kazemi, S.H., Lis, T. and Bagherzadeh, M. (2010) Two New Silver(I) Complexes with 2,4,6-Tris(2-pyridyl)-1,3,5-triazine (Tptz): Preparation, Characterization, Crystal Structure and Alcohol Oxidation Activity in the Presence of Oxone. Polyhedron, 29, 2837-2843. http://dx.doi.org/10.1016/j.poly.2010.07.005

[9] Maghami, M., Farzaneh, F., Simpson, J. and Moazeni, A. (2014) Synthesis, Characterization and Crystal Structure of a Cobalt(II) Coordination Polymer with 2,4,6-Tris(2-pyridyl)-1,3,5-triazine and Its Use as an Epoxidation Catalyst. Polyhedron, 73, 22-29. http://dx.doi.org/10.1016/j.poly.2014.02.012

[10] Chen, D., Milacic, V., Frezza, M. and Dou, Q.P. (2009) Metal Complexes, Their Cellular Targets and Potential for Cancer Therapy. Current Pharmaceutical Design, 15, 777-791. http://dx.doi.org/10.2174/138161209787582183

[11] Hambley, T.W. and Hait, W.N. (2009) Is Anticancer Drug Development Heading in the Right Direction. Cancer Research, 69, 1259-1261. http://dx.doi.org/10.1158/0008-5472.CAN-08-3786

[12] Leung, C.H., Zhong, H.J., Chan, D.S.H. and Ma, D.L. (2013) Bioactive Iridium and Rhodium Complexes as Therapeutic Agents. Coordination Chemistry Reviews, 257, 1764-1776. http://dx.doi.org/10.1016/j.ccr.2013.01.034

[13] Ma, D.L., He, H.Z., Leung, K.H., Chan, D.S. and Leung, C.H. (2013) Bioactive Luminescent Transition-Metal Complexes for Biomedical Applications. Angewandte Chemie International Edition, 52, 7666-7682. http://dx.doi.org/10.1002/anie.201208414

[14] Vogel, A.I. (1994) A Text Book of Quantitative Inorganic Chemistry. Longmans, London.

[15] Bain, G.A. and Berry, J.F. (2008) Diamagnetic Corrections and Pascal's Constants. Journal of Chemical Education, 85, 532-536. http://dx.doi.org/10.1021/ed085p532

[16] Mosmann, T. (1983) Rapid Colorimetric Assay for Cellular Growth and Survival: Application to Proliferation and Cytotoxicity Assays. Journal of Immunological Methods, 65, 55-63. http://dx.doi.org/10.1016/0022-1759(83)90303-4

[17] Gangadevi, V. and Muthumary, J. (2007) Preliminary Studies on Cytotoxic Effect of Fungal Taxol on Cancer Cell Lines. African Journal of Biotechnology, 6, 1382-1386.

[18] Wilson, A.P. (2000) Cytotoxicity and Viability Assays in Animal Cell Culture: A Practical Approach. 3rd Edition, Oxford University Press, Oxford.

[19] Denizot, F. (1986) Lang R. Rapid Colorimetric Assay for Cell Growth and Survival Modifications to the Tetrazolium Dye Procedure Giving Improved Sensitivity and Reliability. Journal of Immunological Methods, 89, 271-277. http://dx.doi.org/10.1016/0022-1759(86)90368-6

[20] Mauceri, H.J., Hanna, N.N., Beckett, M.A., Gorski, D.H., Staba, M.J., Stellato, K.A., Bigelow, K., Heimann, R., Gately, S., Dhanabal, M., Soff, G.A., Sukhatme, V.P., Kufe, D.W. and Weichselbaum, R.R. (1998) Combined Effects of Angiostatin and Ionizing Radiation in Anti-Tumor Therapy. Nature, 394, 287-291. http://dx.doi.org/10.1038/28412

[21] Stylianakis, I., Kolocouris, A., Kolocouris, N., Fytas, G., Foscolos, G.B., Padalko, E., Neyts, J. and Clerq, E.D. (2003) Spiro[pyrrolidine-2,20-adamantanes]: Synthesis, Anti-Influenza Virus Activity and Conformational Properties. Bioorganic \& Medicinal Chemistry Letters, 13, 1699-1703. http://dx.doi.org/10.1016/S0960-894X(03)00231-2

[22] Geary, W.J. (1971) The Use of Conductivity Measurements in Organic Solvents for the Characterisation of Coordination Compounds. Coordination Chemistry Reviews, 7, 81-122. http://dx.doi.org/10.1016/S0010-8545(00)80009-0

[23] Nakamoto, K. (2009) Infrared and Raman Spectra of Inorganic and Coordination Compounds. John Wiley and Sons, Inc., 58B.

[24] Abu-Hussen, A.A.A. and Emara, A.A.A. (2004) Metal Complexes of Some Thiocarbohydrazone Ligands: Synthesis and Structure. Journal of Coordination Chemistry, 57, 973-987. http://dx.doi.org/10.1080/00958970412331272412

[25] Selbin, J. (1964) Metal Oxocations. Journal of Chemical Education, 41, 86. http://dx.doi.org/10.1021/ed041p86

[26] Ferraro, J.R. (1966) Low Frequency Vibrations of Inorganic and Coordination Compounds. Plenum Press, New York.

[27] Beynon, J.H. (1960) Mass Spectrometry and its Applications to Organic Chemistry. Elsevier, Amsterdam.

[28] Zhanglin, Y., Forissier, M., Vedrine, J.C. and Volta, J.C. (1994) On the Mechanism of $n$-Butane Oxidation to Maleic 
Anhydride on VPO Catalysts. II. Study of the Evolution of the VPO Catalysts under $n$-Butane, Butadiene and Furan Oxidation Conditions. Journal of Catalysis, 145, 267-275. http://dx.doi.org/10.1006/jcat.1994.1034

[29] Bencini, A. and Gattechi, D. (1990) EPR of Exchange Coupled System. Springer-Verlach, Berline.

[30] Abou-Hussen, A.A., El-Metwally, N.M., Saad, E.M. and El-Asmy, A.A. (2005) Spectral, Magnetic, Thermal and Electrochemical Studies on Phthaloyl Bis-(Thiosemicarbazide) Complexes. Journal of Coordination Chemistry, 58, 17351749. http://dx.doi.org/10.1080/00958970500262270

[31] Job, P. (1928) Formation and Stability of Inorganic Complexes in Solution. Annales de Chimie (France), 9, 113-203.

[32] Seleem, H.S., El-Inany, G.A., Mousa, M. and Hanafy, F.I. (2009) Spectroscopic Studies on 2-[2-(4-Methylquinolin-2yl) Hydrazono]-1,2-Diphenylethanone Molecule and Its Metal Complexes. Spectrochimica Acta, 74, 869-874. http://dx.doi.org/10.1016/j.saa.2009.08.024

[33] Lever, A.B.P. (1984) Inorganic Electronic Spectroscopy. Elsevier, Amsterdam.

[34] Khalil, S.M.E. (2003) Synthesis, Spectroscopic and Magnetic Studies on Metal Complexes of 5-Methyl-3-(2-Hydroxyphenyl)Pyrazole. Journal of Coordination Chemistry, 56, 1013-1024. http://dx.doi.org/10.1080/0095897031000135289

[35] Khalil, S.M.E. and El-Shafiy, H.F.O. (2000) Vo(IV), Fe(III), Co(II) and Cd(II) Complexes of Asymmetric Schiff Base Ligands $\left(\mathrm{N}_{2} \mathrm{O}_{3}\right)$. Synthesis and Spectroscopic Studies. Synthesis and Reactivity in Inorganic, Metal-Organic, and Nano-Metal Chemistry, 30, 1817-1833. http://dx.doi.org/10.1080/00945710009351871

[36] El-Metwally, N.M., El-Shazly, R.M., Gabr, I.M. and El-Asmy, A.A. (2005) Physical and Spectroscopic Studies on Novel Vanadyl Complexes of Some Substituted Thiosemi-Carbazides. Spectrochimica Acta (A), 61, 1113-1119. http://dx.doi.org/10.1016/j.saa.2004.06.027

[37] Abou-Hussein, A.A. and Linert, W. (2015) Synthesis, Spectroscopic Studies and Inhibitory Activity against Bactria and Fungi of Acyclic and Macrocyclic Transition Metal Complexes Containing a Triamine Coumarine Schiff-Base Ligand. Spectrochimica Acta, 141, 223-232. http://dx.doi.org/10.1016/j.saa.2015.01.063

[38] Delley, B. (2000) From Molecules to Solids with the $\mathrm{DMol}^{3}$ Approach. The Journal of Chemical Physics, 113, 77567764. http://dx.doi.org/10.1063/1.1316015http://dx.doi.org/10.1002/(SICI)1097-461X(1998)68:2<135::AID-QUA6>3.0.CO; $\underline{2-W}$

[39] (2009) Materials Studio v 5.0, Accelrys Software Inc.

[40] Hehre, W.J., Radom, L., Schleyer, P.V.R. and Pople, J.A. (1986) AB Initio Molecular Orbital Theory. John Wiley, New York.

[41] Yousef, T.A., Abu El-Reash, G.M. and El Morshedy, R.M. (2012) Quantum Chemical Calculations, Experimental Investigations and DNA Studies on (E)-2-((3-Hydroxy-naphthalen-2-yl)methylene)-N-(pyridin-2-yl) Hydrazinecarbothioamide and Its Mn(II), Ni(II), Cu(II), Zn(II) and Cd(II) Complexes. Polyhedron, 45, 71-85. http://dx.doi.org/10.1016/j.poly.2012.07.041

[42] Linert, W. and Taha, A. (1994) Coordination of Solvent Molecules to Square-Planar Mixed-Ligand Nickel (II) Complexes-A Thermodynamic and Quantum-Mechanical Study. Journal of the Chemical Society, Dalton Transactions, 1994, 1091-1095. http://dx.doi.org/10.1039/dt9940001091

[43] Govindarajan, M., Periandy, S. and Carthigayen, K. (2012) FT-IR and FT-Raman Spectra, Thermodynamical Behavior, HOMO and LUMO, UV, NLO Properties, Computed Frequency Estimation Analysis and Electronic Structure Calculations on a Bromotoluene. Spectrochimica Acta, 97, 411-422. http://dx.doi.org/10.1016/j.saa.2012.06.028

[44] Abu El-Reash, G.M., El-Gammal, O.A., Ghazy, S.E. and Radwan, A.H. (2013) Characterization and Biological Studies on $\mathrm{Co}(\mathrm{II}), \mathrm{Ni}(\mathrm{II})$ and $\mathrm{Cu}(\mathrm{II})$ Complexes of Carbohydrazones Ending by Pyridyl Ring. Spectrochimica Acta, 104, $26-34$. http://dx.doi.org/10.1016/j.saa.2012.11.008

[45] Pearson, R.G. (1989) Absolute Electronegativity and Hardness: Applications to Organic Chemistry. Journal of Organic Chemistry, 54, 1423-1430. http://dx.doi.org/10.1021/jo00267a034

[46] Padmanabhan, J., Parthasarathi, R., Subramanian, V. and Chattaraj, P. (2007) Electrophilicity-Based Charge-Transfer Descriptor. The Journal of Physical Chemistry, 111, 1358-1361. http://dx.doi.org/10.1021/jp0649549

[47] Parthasarathi, R., Padmanabhan, J., Sarkar, U., Maiti, B., Subramanian, V. and Chattaraj, P.K. (2003) Toxicity Analysis of Benzidine through Chemical Reactivity and Selectivity Profiles: A DFT Approach. Journal of Molecular Structure, 2, 798-813.

[48] Scrocco, E. and Tomasi, J. (1978) Electronic Molecular Structure, Advances in Quantum Chemistry. Academic Press, Cambridge, 115-193.

[49] Luque, F.J., López, J.M. and Orozco, M. (2000) Perspective on "Electrostatic Interactions of a Solute with a Continuum. A Direct Utilization of AB initio Molecular Potentials for the Prevision of Solvent Effects". Theoretical Chemistry Accounts, 103, 343-345. http://dx.doi.org/10.1007/s002149900013 
[50] Okulik, N and Ubert, A.H.J. (2005) Theoretical Analysis of the Reactive Sites of Non-Steroidal Anti-Inflammatory Drugs. J. Molecular. Design, 4, 17-30.

[51] Politzer, P., Laurence, P.R. and Jayasuriya, K. (1985) Molecular Electrostatic Potentials: An Effective Tool for the Elucidation of Biochemical Phenomena. Environmental Health Perspectives, 61, 191-200. http://dx.doi.org/10.1289/ehp.8561191

[52] Scrocco, E. and Tomasi, J. (1973) The Electrostatic Molecular Potential as a Tool for the Interpretation of Molecular Properties. New Concepts II, Springer, 95-170. http://dx.doi.org/10.1007/3-540-06399-4_6

[53] Aljahdali, M. and El-Sherif, A.A. (2013) Synthesis, Characterization, Molecular Modeling and Biological Activity of Mixed Ligand Complexes of Cu(II), Ni(II) and Co(II) Based on 1,10-Phenanthroline and Novel Thiosemicarbazone. Inorganica Chimica Acta, 407, 58-68. http://dx.doi.org/10.1016/j.ica.2013.06.040

[54] EL-Saied, F.A., Shakdofa, M.M.E. and Al-Hakimi, A.N. (2011) Synthesis, Characterization and Biological Studies of New Mn(II), Ni(II), Co(II), Cu(II) and Zn(II) of 2-(Benzothiazol-2-yl)-N'-(2,5-dihydroxybenzylidene)acetohydrazide. Journal of the Korean Chemical Society, 55, 19-27. http://dx.doi.org/10.5012/jkcs.2011.55.1.019

[55] El-Tabl, A.S., El-Saied, F.A. and Al-Hakimi, A.N. (2008) Spectroscopic Characterization and Biological Activity of Metal Complexes with an ONO Trifunctionalized Hydrazone Ligand. Journal of Coordination Chemistry, 61, 23802401. http://dx.doi.org/10.1080/00958970801914041

[56] Israel, Y. and Meites, L. (1976) Vanadium. In: Bard, A.J., Ed., Encyclopedia of Electrochemistry of the Elements, Vol. VII, Chap. VII-2, Marcel Dekker Inc., New York, 336-378. 


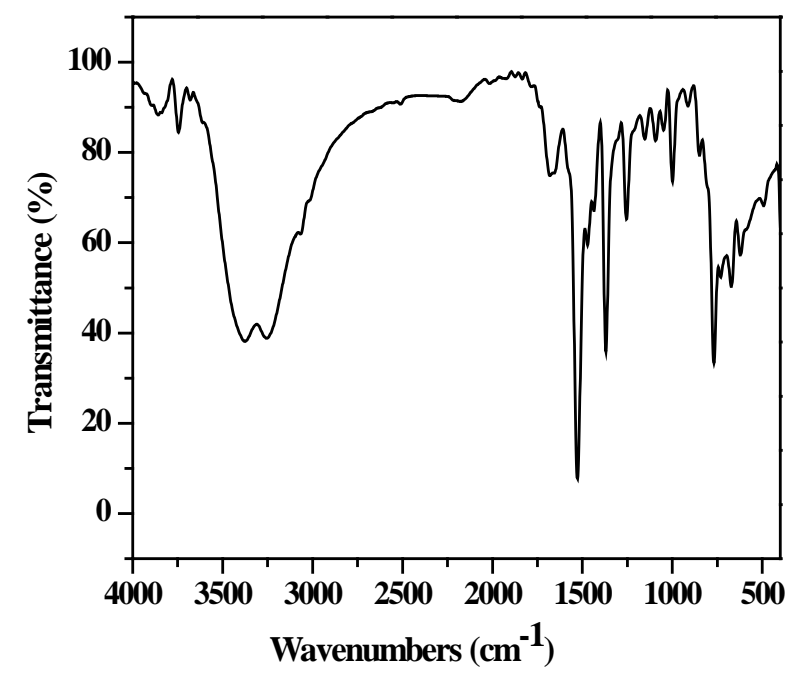

Figure S1. IR spectrum of $\mathrm{L}^{1}$ (TPTZ).

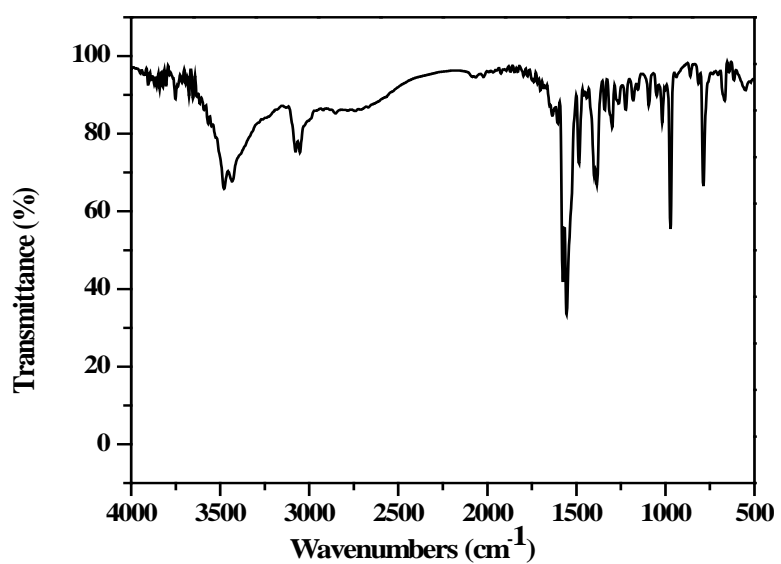

Figure S2. IR spectrum of the $\left[\mathrm{VO}\left(\mathrm{L}^{1}\right)(2,4\right.$-pentadionate)] $\mathrm{Cl} \cdot 4 \mathrm{HCl}$ complex.

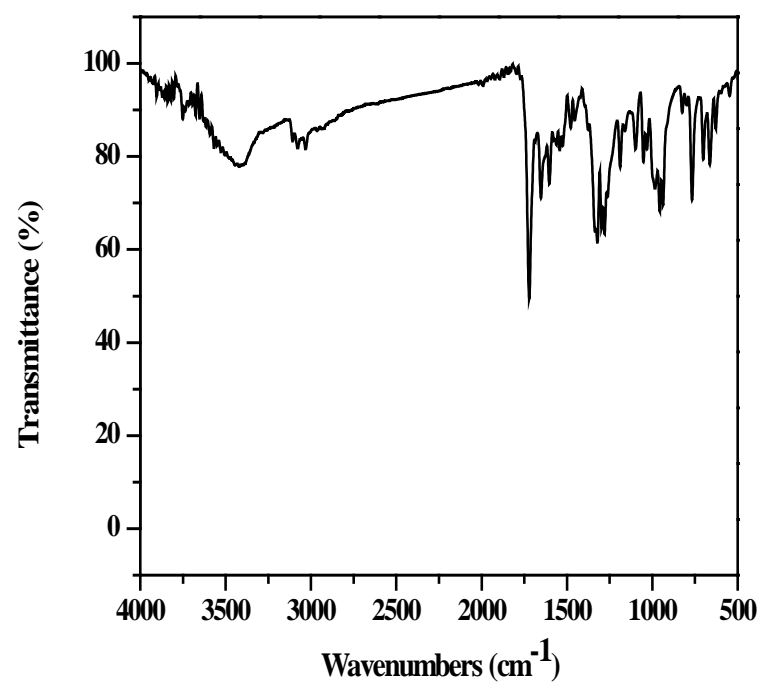

Figure S3. IR spectrum of the $\left[\mathrm{V}_{2} \mathrm{O}_{2}\left(\mathrm{~L}^{1}\right)\left(\mathrm{SO}_{4}\right)_{2}(\mathrm{EtOH})_{5 / 2}\right]$ complex. 


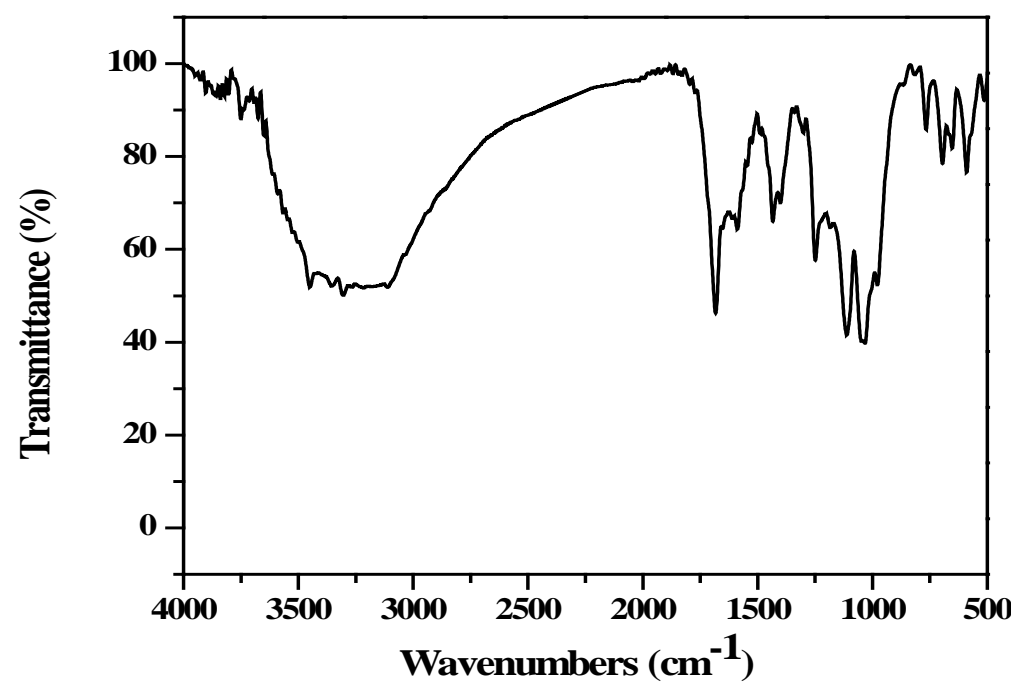

Figure S4. IR spectrum of the $\left[\mathrm{V}_{2} \mathrm{O}_{2}\left(\mathrm{~L}^{1}\right)\left(\mathrm{SO}_{4}\right)_{2}(\mathrm{EtOH})_{3 / 2}\left(\mathrm{H}_{2} \mathrm{O}\right)_{1 / 2}\right]$ complex.

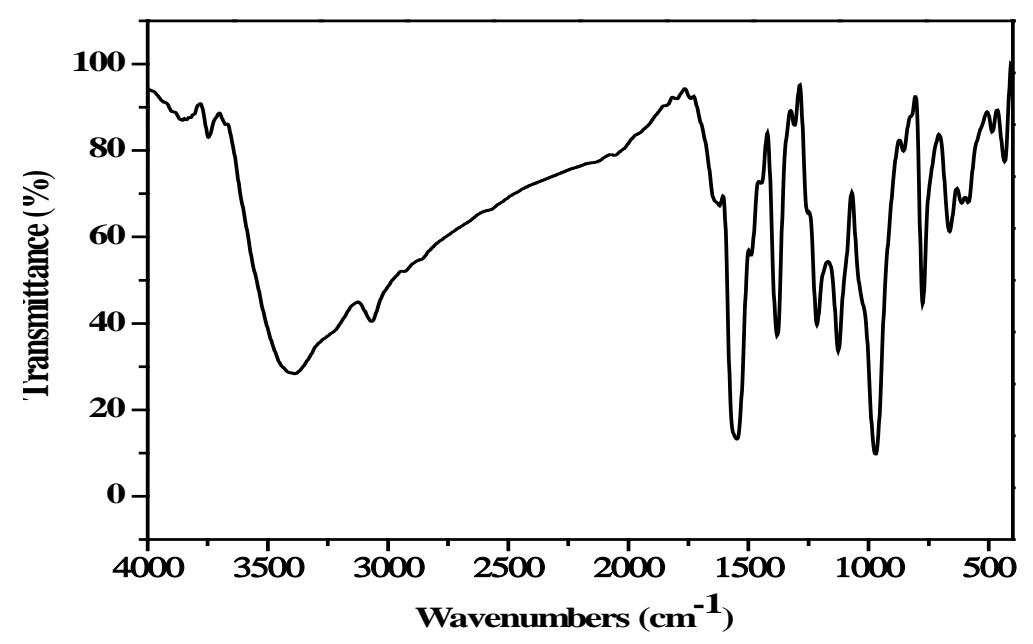

Figure S5. IR spectrum of the $\left[\mathrm{VO}\left(\mathrm{L}^{1}\right) \mathrm{SO}_{4}\left(\mathrm{H}_{2} \mathrm{O}\right)_{3 / 2}\right] \cdot 2.5 \mathrm{H}_{2} \mathrm{O}$ complex.

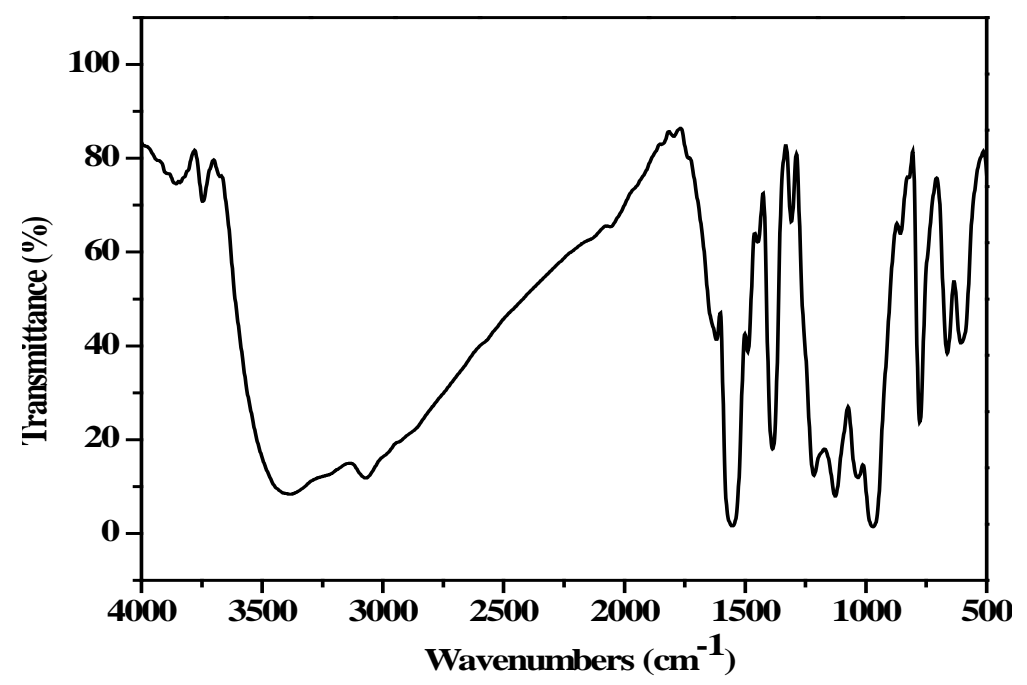

Figure S6. IR spectrum of the $\left[\mathrm{V}_{2} \mathrm{O}_{2}\left(\mathrm{~L}^{1}\right)\left(\mathrm{SO}_{4}\right)_{2}\left(\mathrm{H}_{2} \mathrm{O}\right)\right] \cdot \mathrm{H}_{2} \mathrm{O}$ complex. 


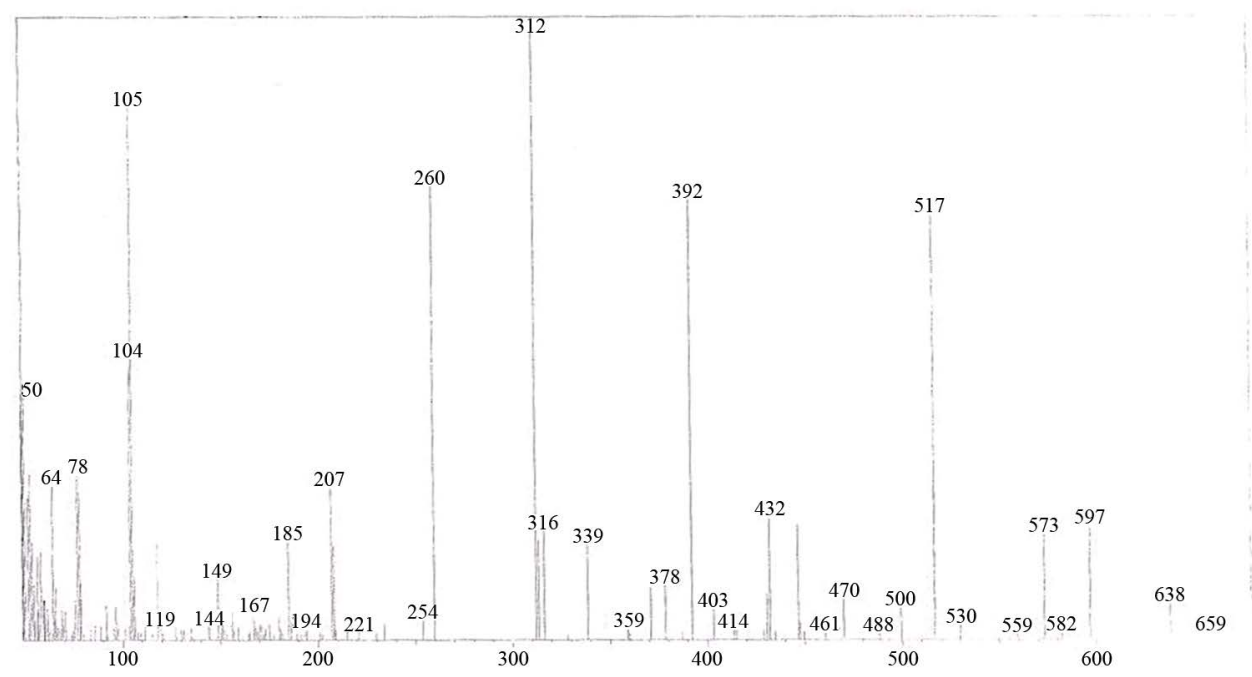

Figure S7. The mass spectrum of $\left[\mathrm{VO}\left(\mathrm{L}^{1}\right)(2,4\right.$-pentadionate) $] \mathrm{Cl} \cdot 4 \mathrm{HCl}$ complex.
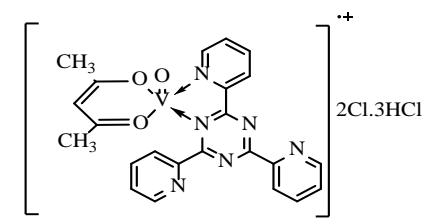

$\mathrm{m} / \mathrm{z}=659.2(658.7)(1.2 \%)$ $\stackrel{-3 \mathrm{HCl}+\mathrm{Cl}}{\longrightarrow}$

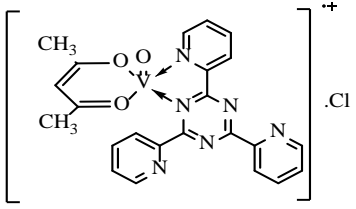

$+3 \mathrm{H}^{+} \mathrm{m} / \mathrm{z}=517$ (513.8) (68\%)

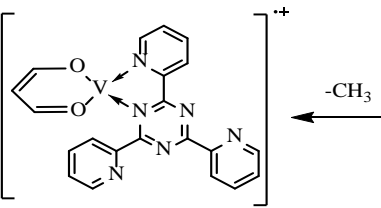

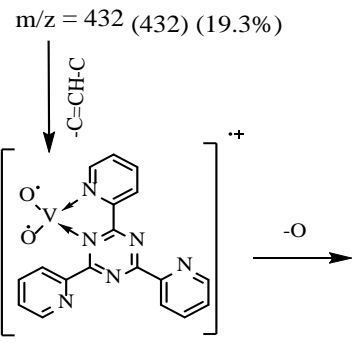

$\mathrm{m} / \mathrm{z}=447$ (447) (18.2\%)

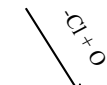

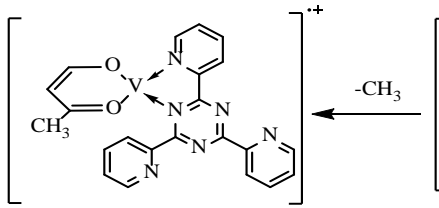<smiles></smiles>
$\mathrm{CH}_{3}=\mathrm{O} \quad \mathrm{N}=\mathrm{N}$ in ${ }^{N}{ }^{N}$ $\stackrel{+}{\mathrm{H}} / \mathrm{z}=461(462)(1.2 \%)$

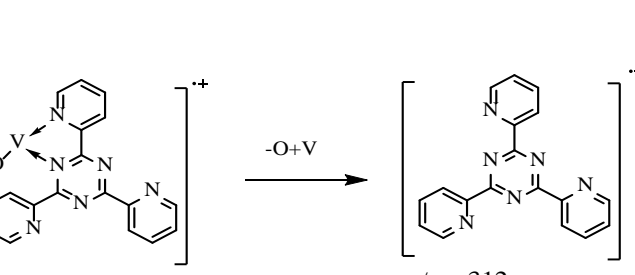

$-3 \mathrm{H} \mathrm{m} / \mathrm{z}=392.2(395.3)(70.4 \%) \quad \mathrm{m} / \mathrm{z}=378.4$ (379.3) (8.6\%)
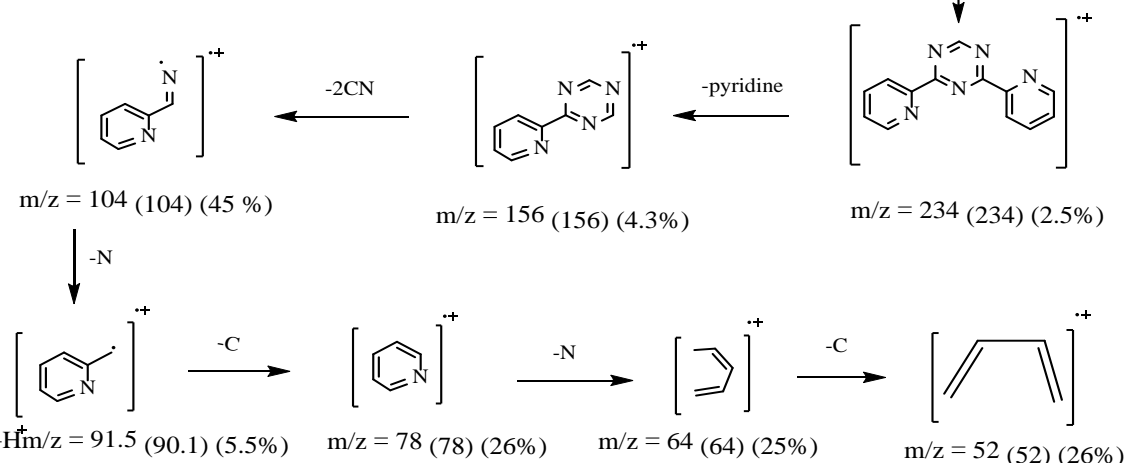

Figure S8. The fragmentation pattern of $\left[\mathrm{VO}\left(\mathbf{L}^{\mathbf{1}}\right)(2,4\right.$-pentadionate) $\mathrm{Cl} \cdot 4 \mathrm{HCl}$ complex. 


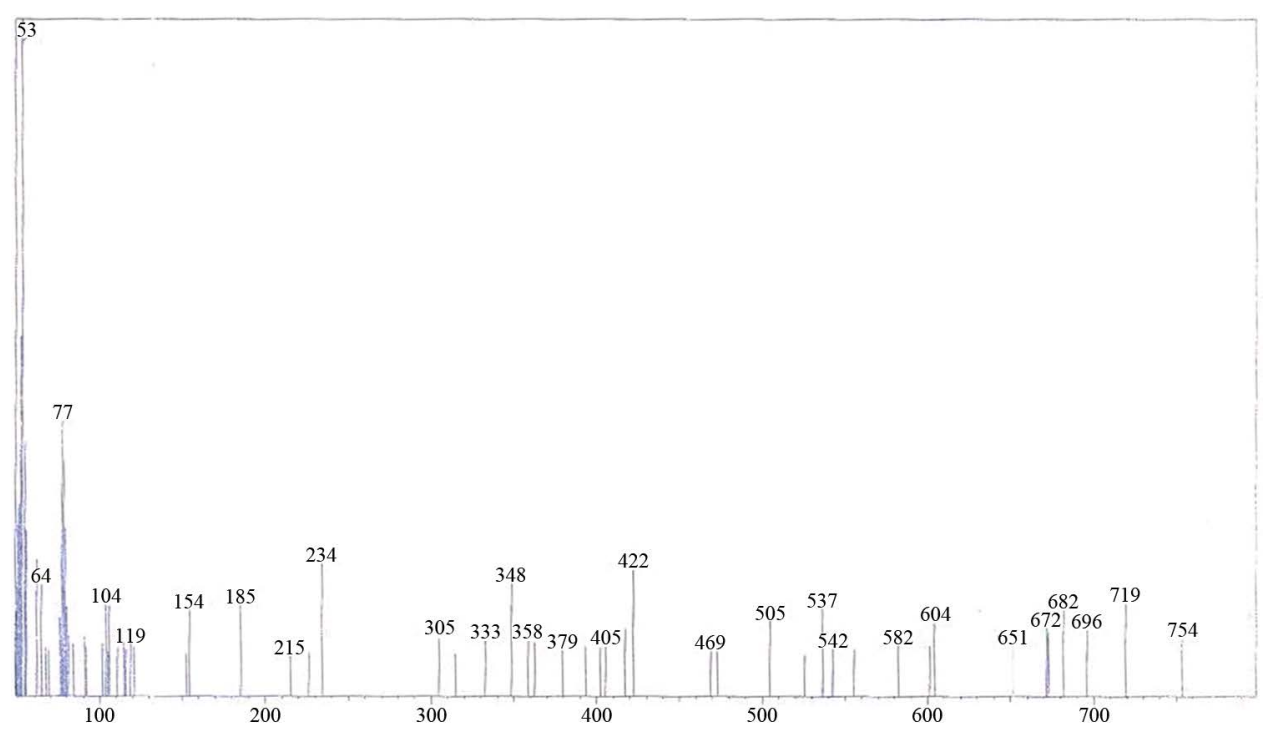

Figure S9. The mass spectrum of $\left[\mathrm{V}_{2} \mathrm{O}_{2}\left(\mathbf{L}^{1}\right)\left(\mathrm{SO}_{4}\right)_{2}(\mathrm{EtOH})_{5 / 2}\right]$.

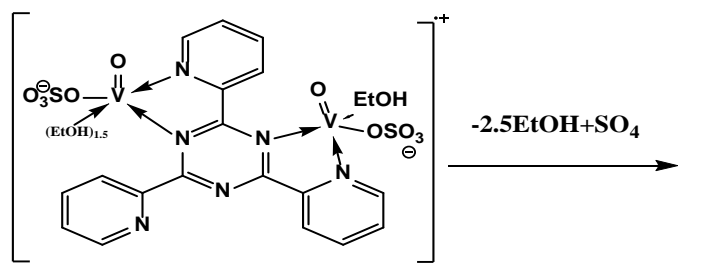

$\mathrm{m} / \mathrm{z}=753.6$ (753.5) (9\%)

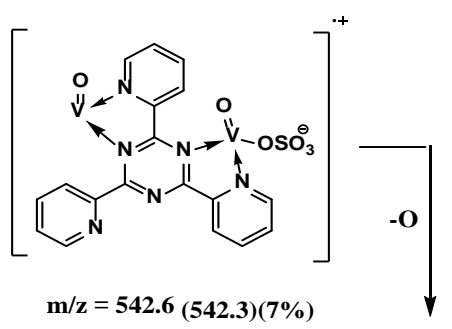

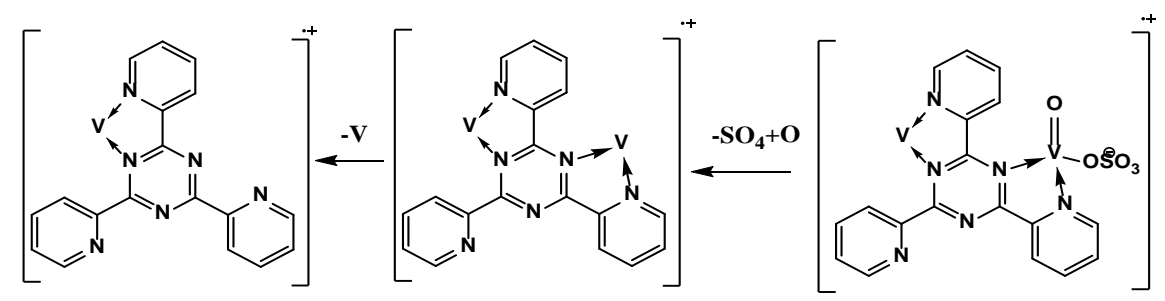

$\mathrm{m} / \mathrm{z}=362.5(363.3)(8 \%)$ $\downarrow-\mathbf{v}$

$+3 \stackrel{+}{H} \mathrm{~m} / \mathrm{z}=417.2(414.2)(10 \%)$

$\mathrm{m} / \mathrm{z}=525.7$ (526.3) (6\%)<smiles>c1ccc(-c2nc(-c3ccccn3)nc(-c3ccccn3)n2)nc1</smiles>

$+3 \stackrel{+}{\mathrm{H} m} / \mathbf{z}=314.8$ (312.3) (6\%)

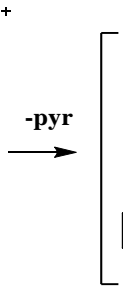<smiles>c1ccc(-c2cnc(-c3ccccn3)nn2)nc1</smiles><smiles>CC(C)C</smiles>

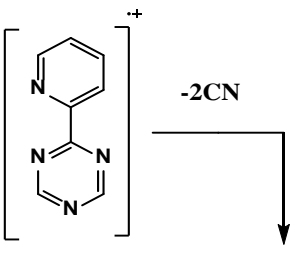<smiles>N#C[c+]1cc[cH+]1</smiles>

$\mathrm{m} / \mathrm{z}=\mathbf{5 2 . 6}(52)(100 \%)$

$\mathbf{m} / \mathbf{z}=234$ (234) (20\%)

$-\mathrm{H}^{\dagger} \mathrm{m} / \mathrm{z}=155$ (156) (13\%)

Figure S10. The fragmentation pattern of $\left[\mathrm{V}_{2} \mathrm{O}_{2}\left(\mathrm{~L}^{1}\right)\left(\mathrm{SO}_{4}\right)_{2}(\mathrm{EtOH})_{5 / 2}\right]$. 


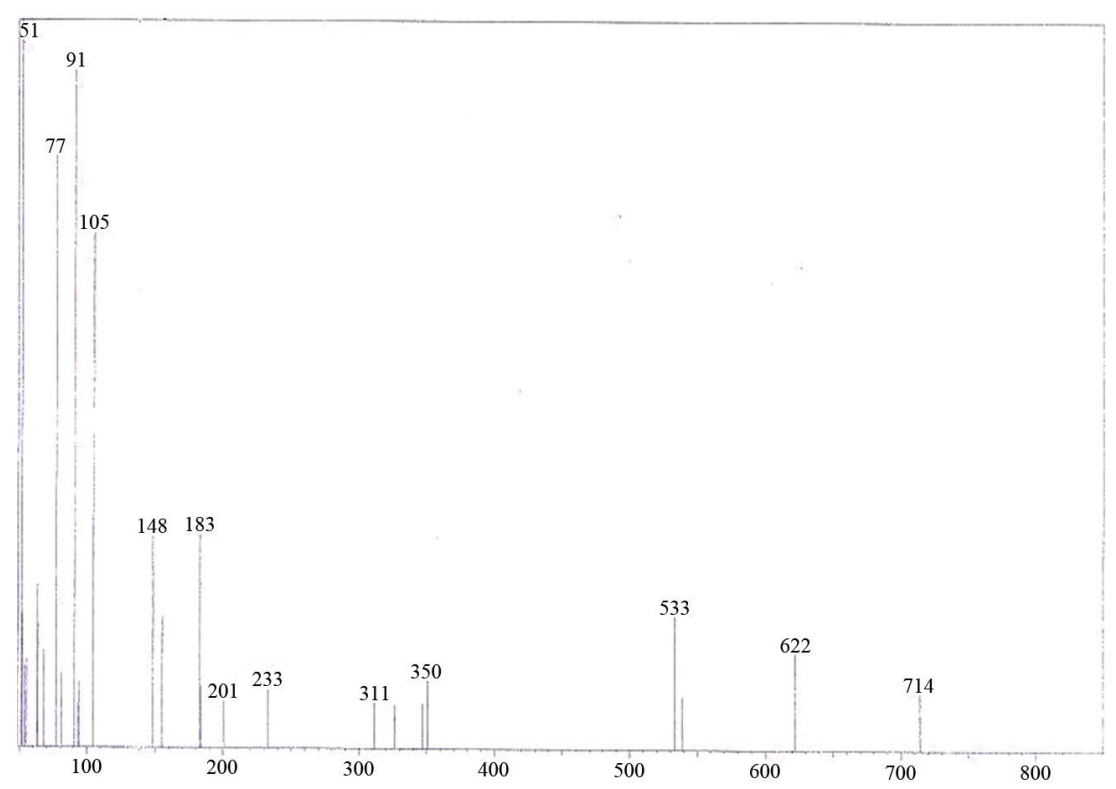

Figure S11. The mass spectrum of $\left[\mathrm{V}_{2} \mathrm{O}_{2}\left(\mathrm{~L}^{1}\right)\left(\mathrm{SO}_{4}\right)_{2}(\mathrm{EtOH})_{3 / 2}\left(\mathrm{H}_{2} \mathrm{O}\right)_{1 / 2}\right]$.

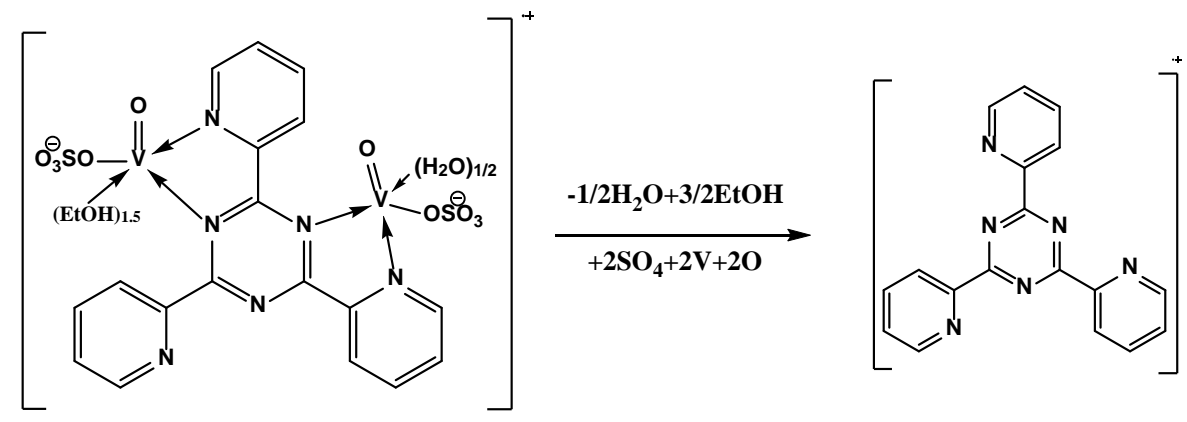

$-2+\mathbf{H m} / \mathbf{z}=713.9(716.4)(8 \%)$

$\mathrm{m} / \mathrm{z}=311.4(312.3)(6 \%)$

$\downarrow$-pyridine

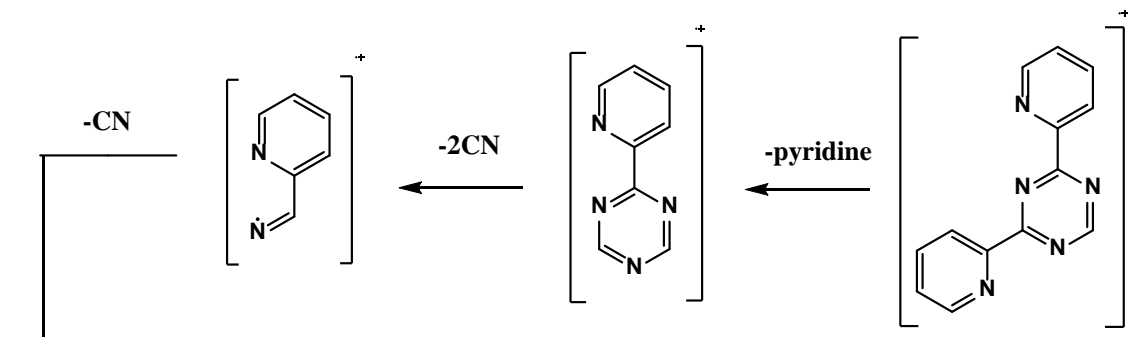

$\mathrm{m} / \mathbf{z}=104.7(104.1)(71 \%) \quad \mathrm{m} / \mathbf{z}=155.3(156.2)(18 \%) \quad-H \mathrm{H} / \mathbf{z}=233(234)(8 \%)$

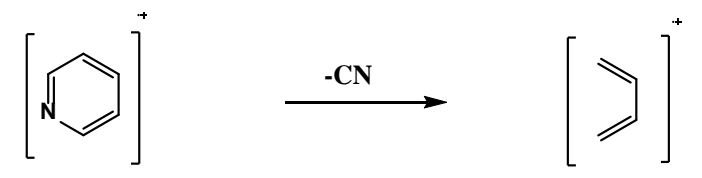

$\stackrel{+}{\mathrm{H} m} / \mathbf{z}=77(78.1)(81 \%) \quad \mathbf{m} / \mathbf{z}=51.3(52.1)(100 \%)$

Figure S12. The fragmentation pattern of $\left[\mathrm{V}_{2} \mathrm{O}_{2}\left(\mathbf{L}^{1}\right)\left(\mathrm{SO}_{4}\right)_{2}(\mathrm{EtOH})_{3 / 2}\left(\mathrm{H}_{2} \mathrm{O}\right)_{1 / 2}\right]$. 


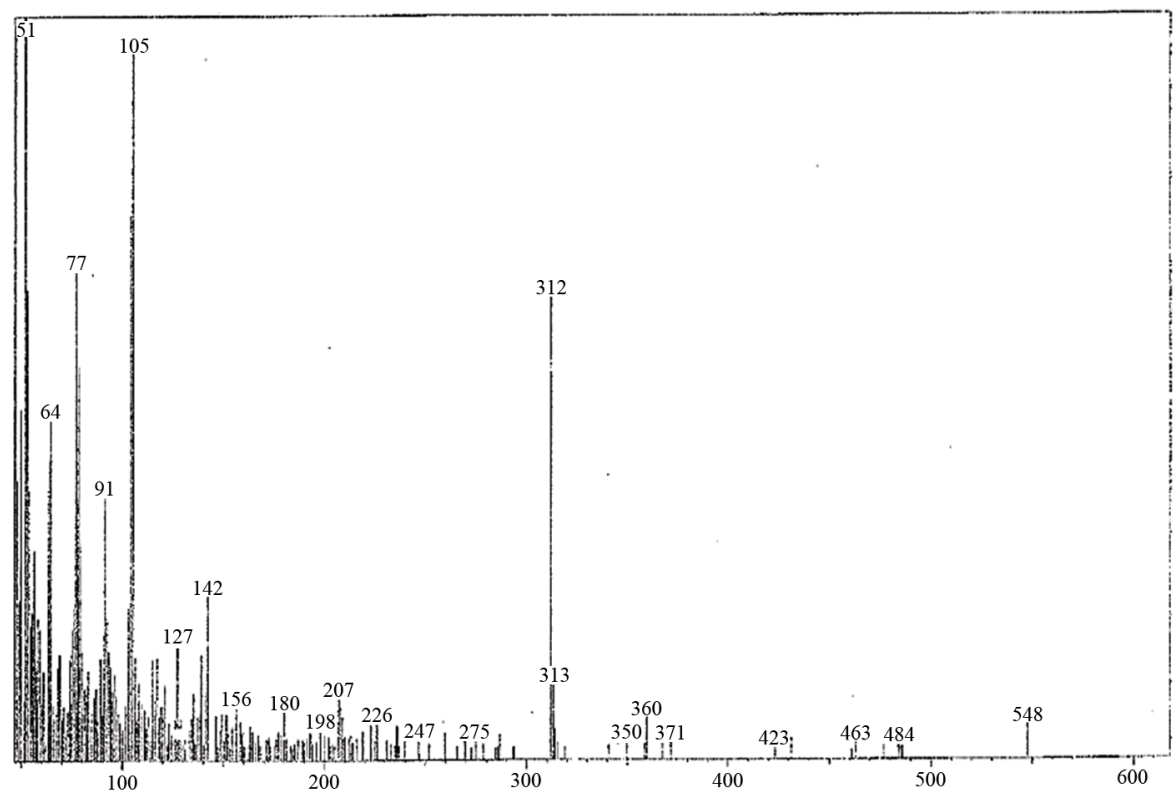

Figure S13. The mass spectrum of $\left[\mathrm{VO}\left(\mathbf{L}^{1}\right) \mathrm{SO}_{4}\left(\mathrm{H}_{2} \mathrm{O}\right)_{3 / 2}\right] \cdot 2.5 \mathrm{H}_{2} \mathrm{O}$.

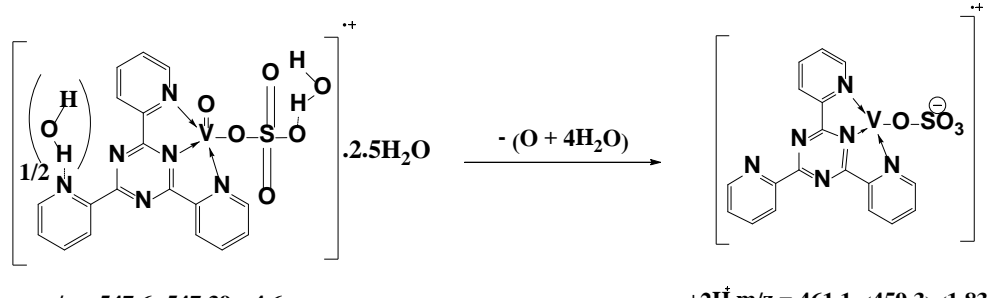

$\mathrm{m} / \mathrm{z}=547.6(547.39)(4.6)$

$+2 \mathrm{H}^{\dagger} \mathrm{m} / \mathrm{z}=461.1$ (459.3) (1.83)
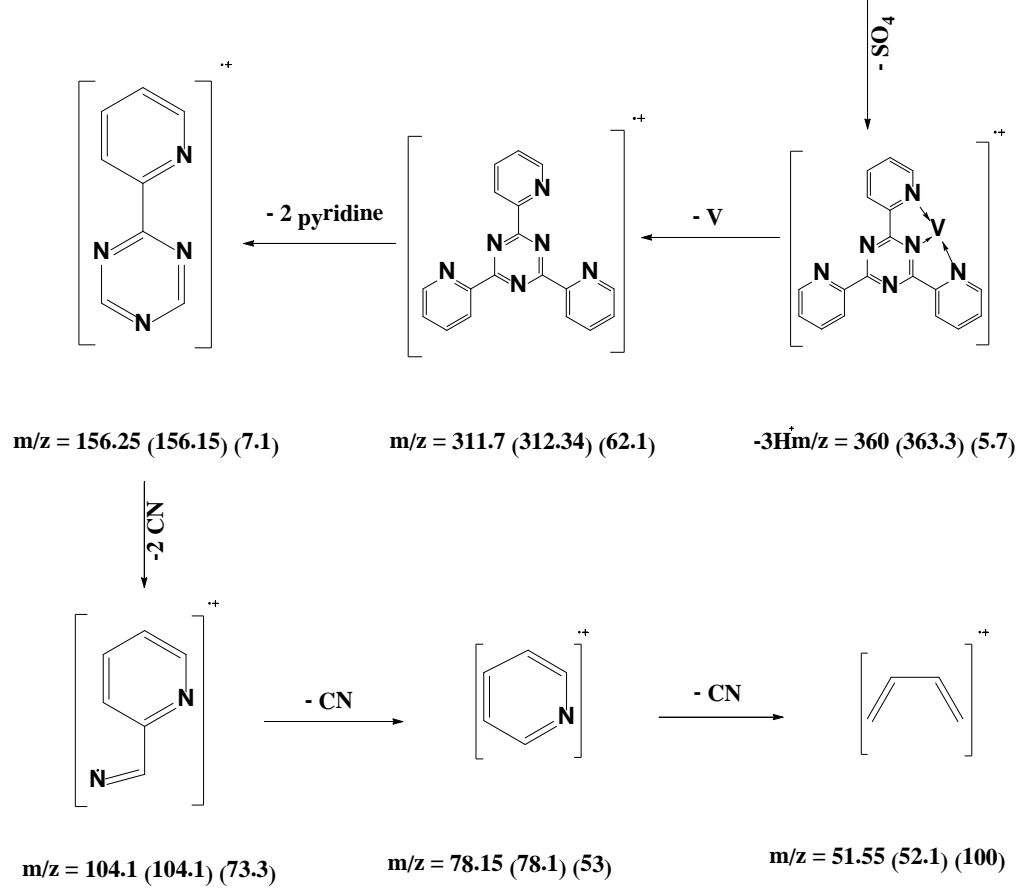

Figure S14. The fragmentation pattern of $\left[\mathrm{VO}\left(\mathbf{L}^{1}\right) \mathrm{SO}_{4}\left(\mathrm{H}_{2} \mathrm{O}\right)_{3 / 2}\right] \cdot 2.5 \mathrm{H}_{2} \mathrm{O}$. 


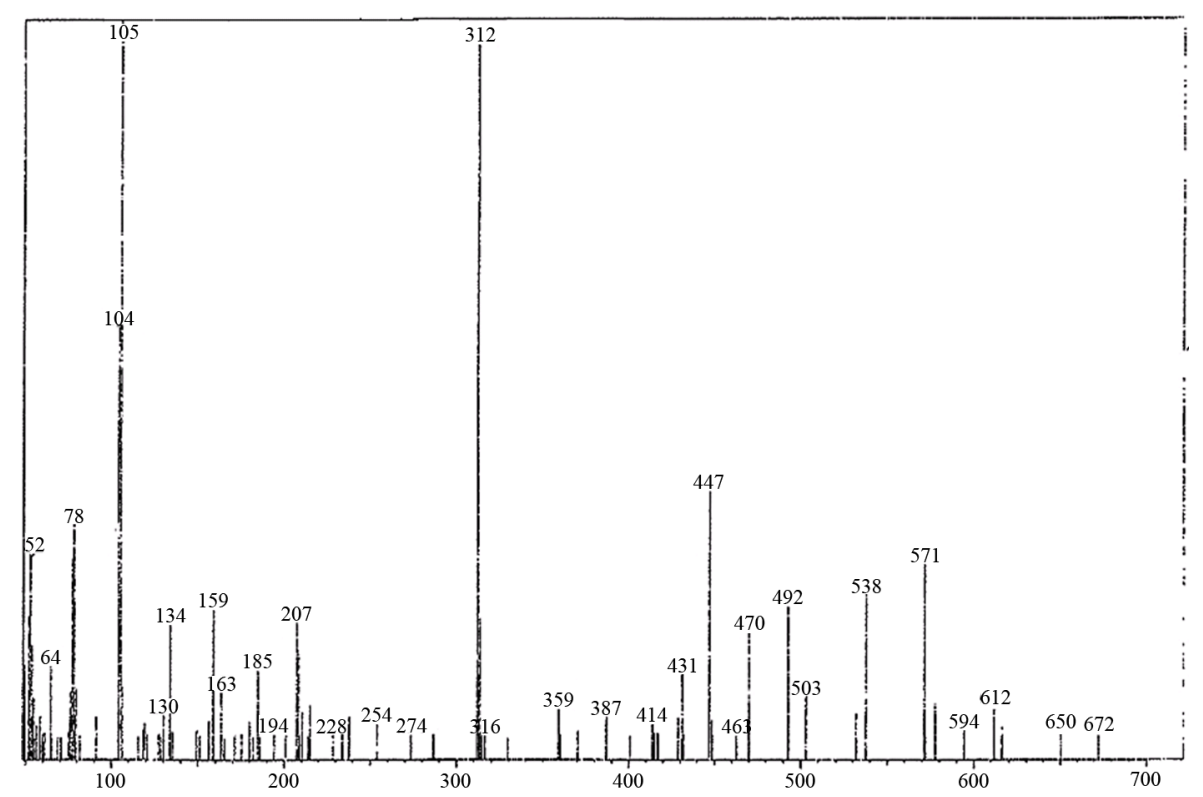

Figure S15. The mass spectrum of $\left[\mathrm{V}_{2} \mathrm{O}_{2}\left(\mathbf{L}^{1}\right)\left(\mathrm{SO}_{4}\right)_{2}\left(\mathrm{H}_{2} \mathrm{O}\right)\right] \cdot \mathrm{H}_{2} \mathrm{O}$.
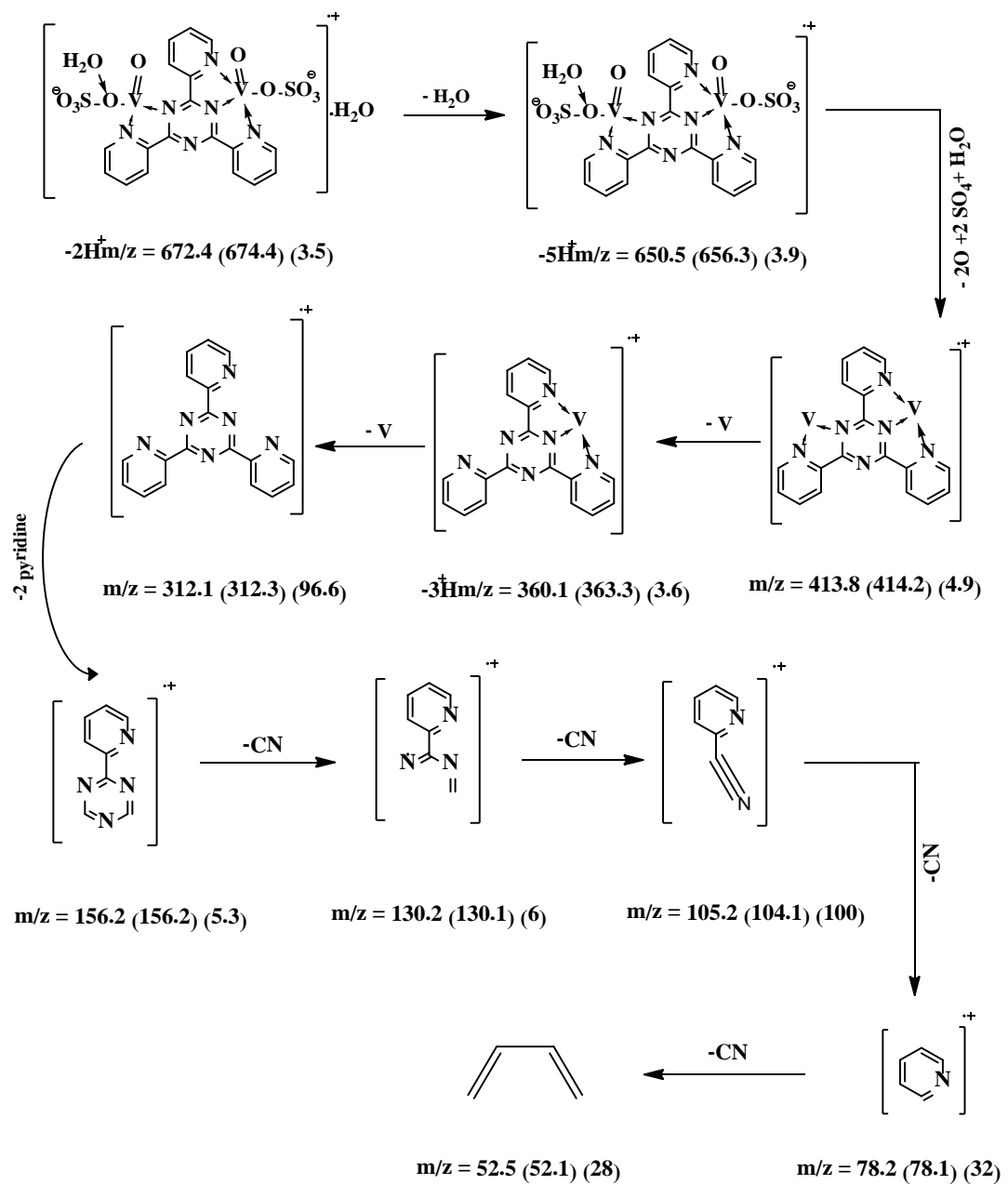

Figure S16. The fragmentation pattern of $\left[\mathrm{V}_{2} \mathrm{O}_{2}\left(\mathrm{~L}^{1}\right)\left(\mathrm{SO}_{4}\right)_{2}\left(\mathrm{H}_{2} \mathrm{O}\right)\right] \cdot \mathrm{H}_{2} \mathrm{O}$. 


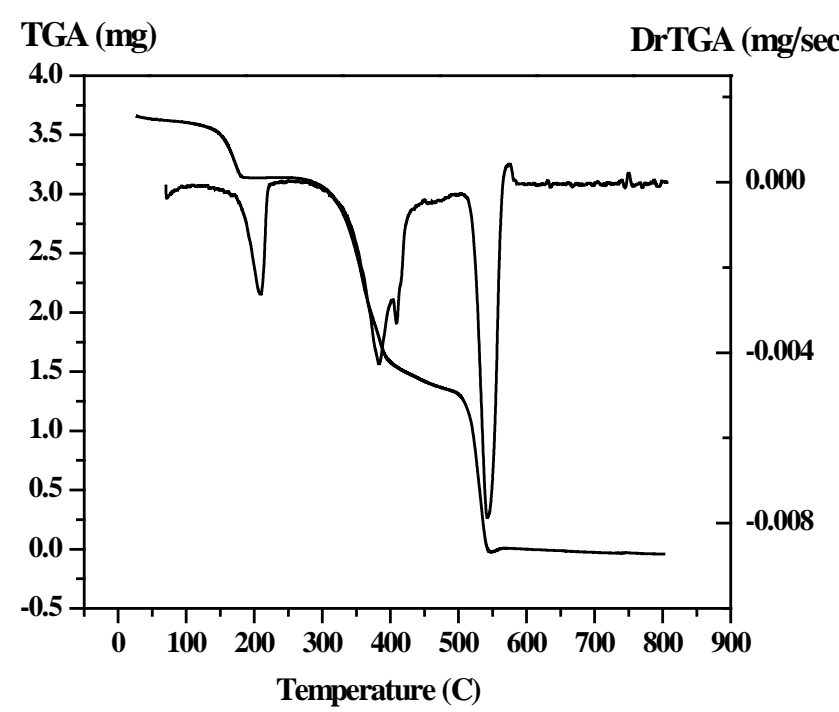

Figure S17. The TGA curve of $\left[\mathrm{VO}\left(\mathbf{L}^{\mathbf{1}}\right)(2,4\right.$-pentadionate)] $\mathrm{Cl} \cdot 4 \mathrm{HCl}$.

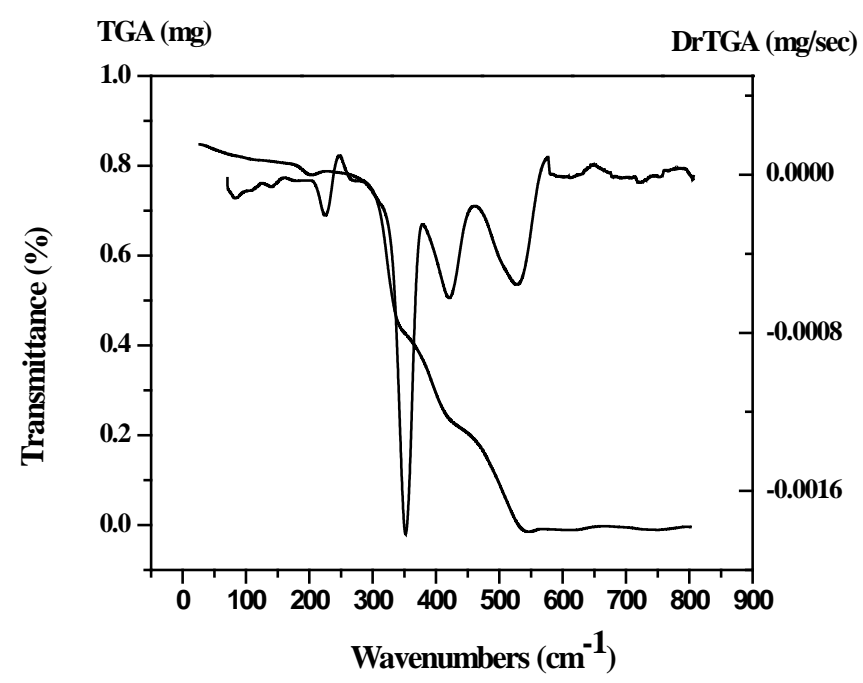

Figure S18. The TGA curve of $\left[\mathrm{V}_{2} \mathrm{O}_{2}\left(\mathbf{L}^{1}\right)\left(\mathrm{SO}_{4}\right)_{2}(\mathrm{EtOH})_{5 / 2}\right]$.

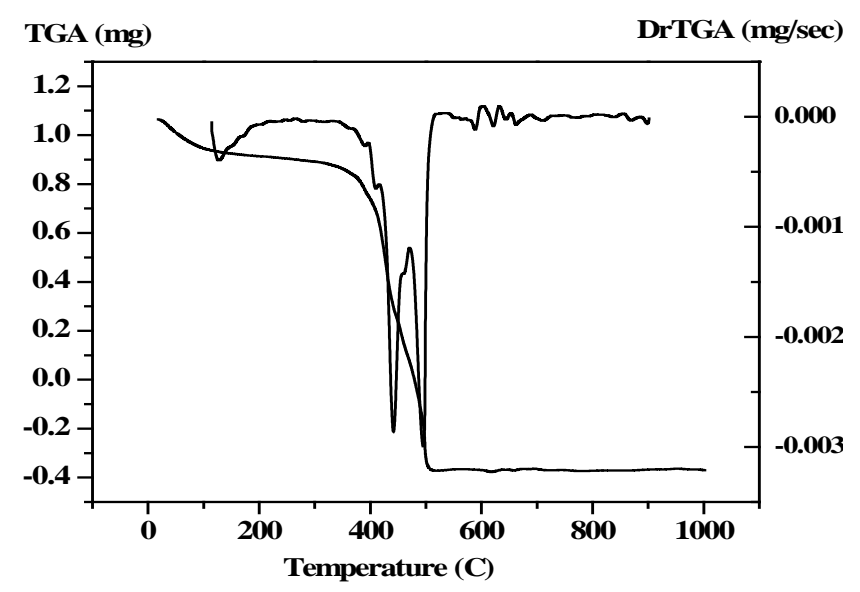

Figure S19. The TGA curve of $\left[\mathrm{VO}\left(\mathrm{L}^{1}\right) \mathrm{SO}_{4}\left(\mathrm{H}_{2} \mathrm{O}\right)_{3 / 2}\right] \cdot 2.5 \mathrm{H}_{2} \mathrm{O}$. 


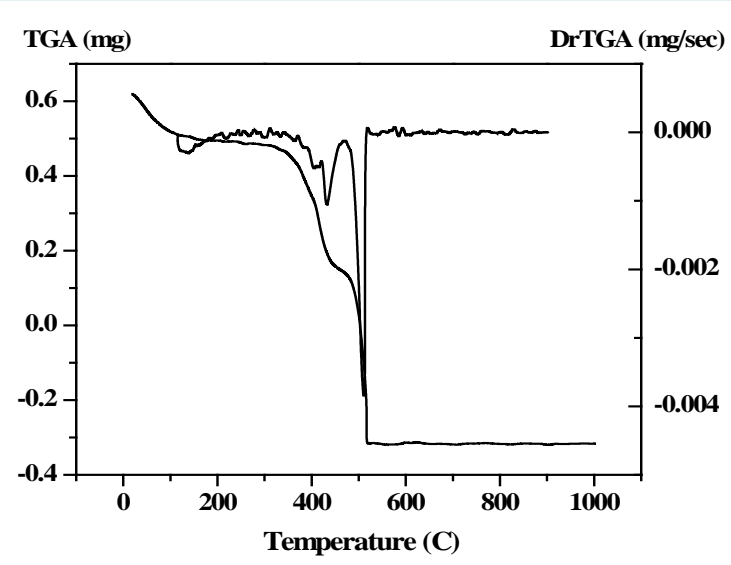

Figure S20. The TGA curve of $\left[\mathrm{V}_{2} \mathrm{O}_{2}\left(\mathrm{~L}^{1}\right)\left(\mathrm{SO}_{4}\right)_{2}\left(\mathrm{H}_{2} \mathrm{O}\right)\right] \cdot \mathrm{H}_{2} \mathrm{O}$.

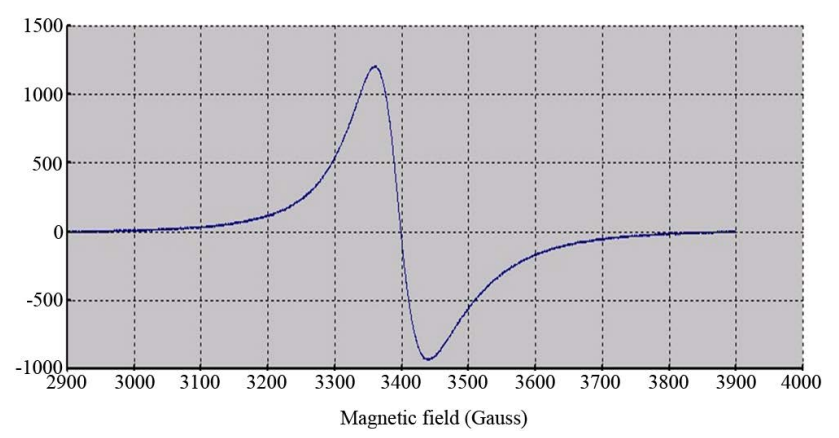

Figure S21. X-band ESR spectrum of $\left[\mathrm{VO}\left(\mathrm{L}^{1}\right)(2,4\right.$-pentadionate)] $\mathrm{Cl} \cdot 4 \mathrm{HCl}$.

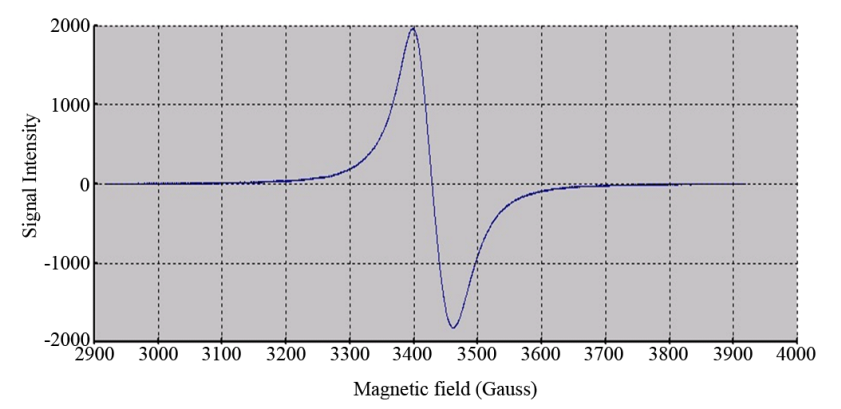

Figure S22. X-band ESR spectrum of $\left[\mathrm{VO}\left(\mathrm{L}^{1}\right) \mathrm{SO}_{4}\left(\mathrm{H}_{2} \mathrm{O}\right)_{3 / 2}\right] \cdot 2.5 \mathrm{H}_{2} \mathrm{O}$.

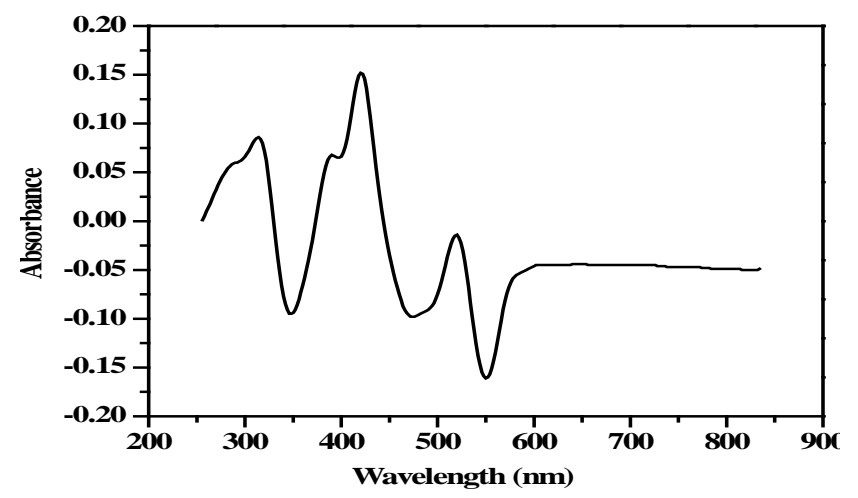

Figure S23. The electronic spectra of $\left[\mathrm{V}_{2} \mathrm{O}_{2}\left(\mathrm{~L}^{1}\right)\left(\mathrm{SO}_{4}\right)_{2}\left(\mathrm{H}_{2} \mathrm{O}\right)\right] \cdot \mathrm{H}_{2} \mathrm{O}$. 


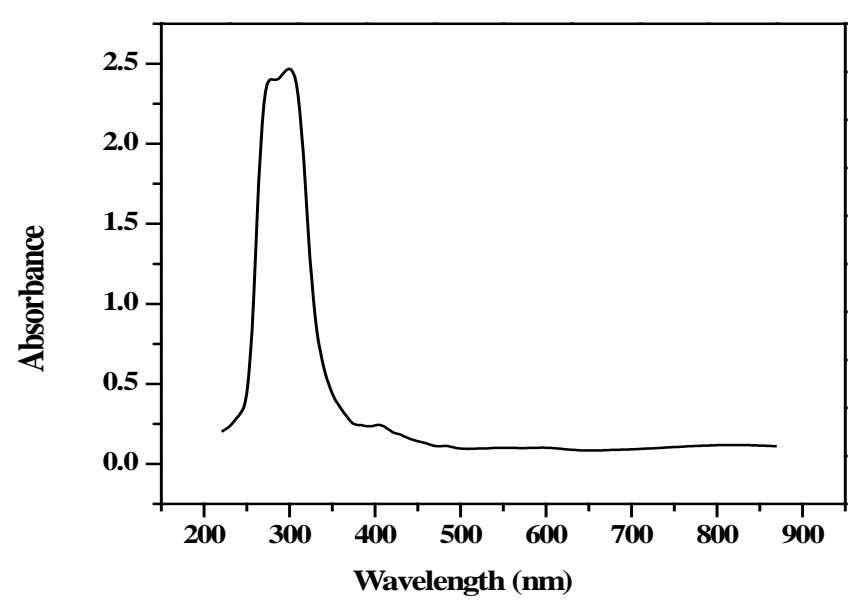

Figure S24. Electronic spectra of $\left[\mathrm{V}_{3} \mathrm{O}_{3}\left(\mathbf{L}^{1}\right)\left(\mathrm{SO}_{4}\right)_{3}(\mathrm{EtOH})_{1 / 2}\left(\mathrm{H}_{2} \mathrm{O}\right)_{3 / 2}\right]$.

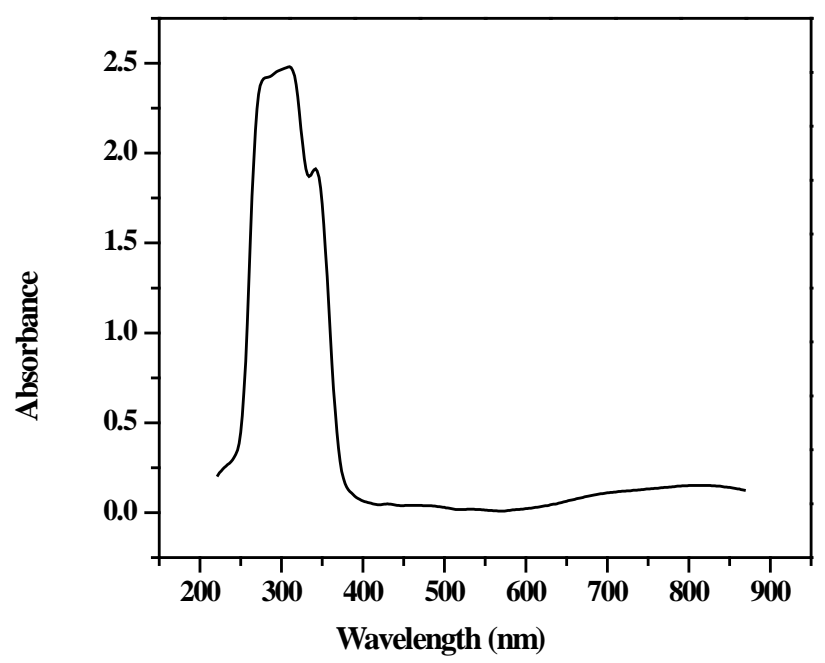

Figure S25. The electronic spectrum of $\left[\operatorname{VO}\left(\mathbf{L}^{1}\right)(2,4\right.$-pentadionate) $]$ $\mathrm{Cl} \cdot 4 \mathrm{HCl}$.

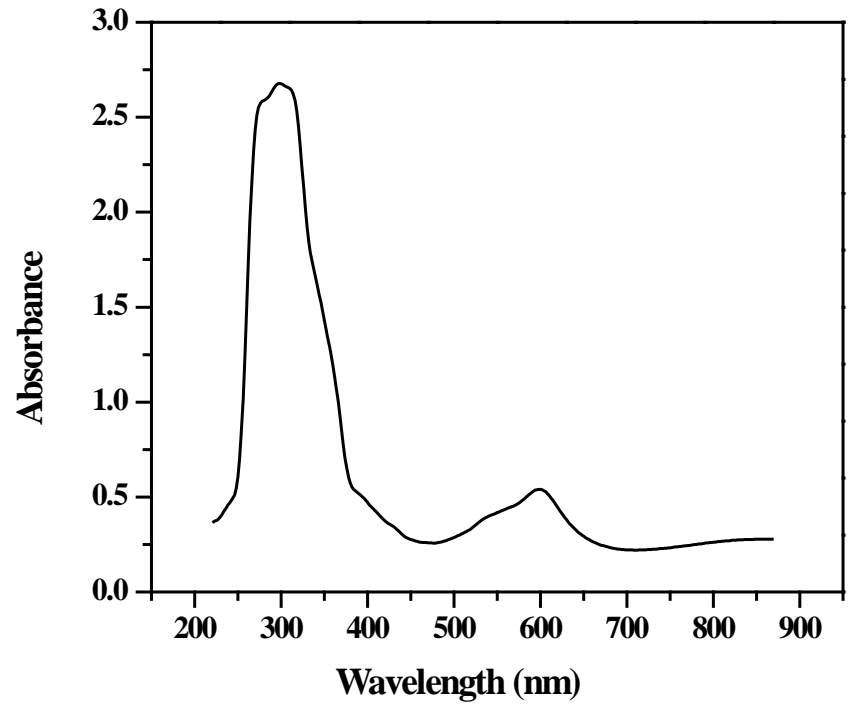

Figure S26. The electronic spectrum of $\left[\mathrm{V}_{2} \mathrm{O}_{2}\left(\mathrm{~L}^{1}\right)\left(\mathrm{SO}_{4}\right)_{2}(\mathrm{EtOH})_{5 / 2}\right]$. 


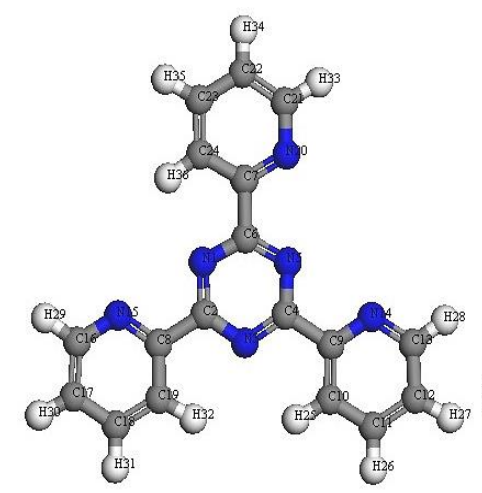

(a)

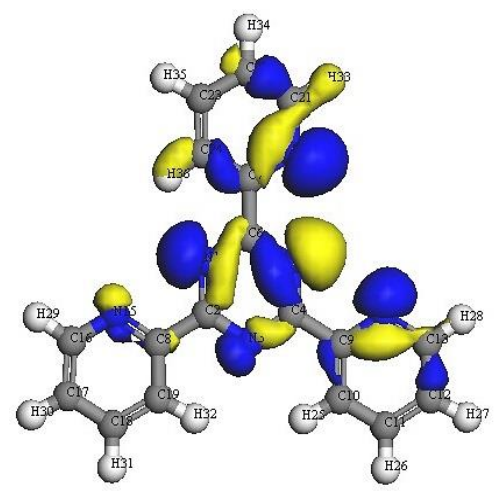

(c)

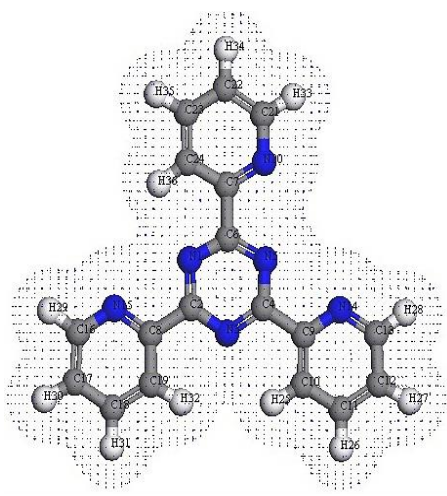

(b)

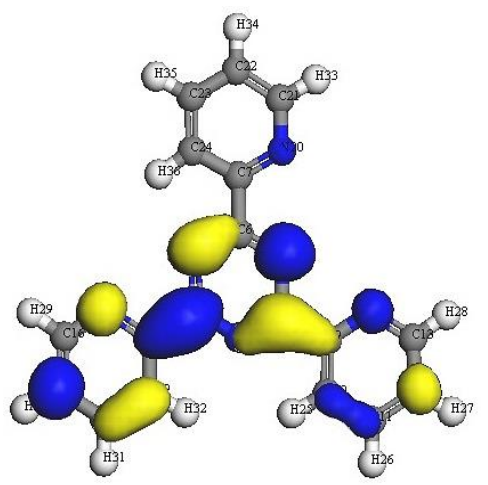

(d)

Figure S27. Molecular modeling of (a) $\left(\mathbf{L}^{1}\right)$, (b) electron density, (c) HOMO and (d) LUMO.

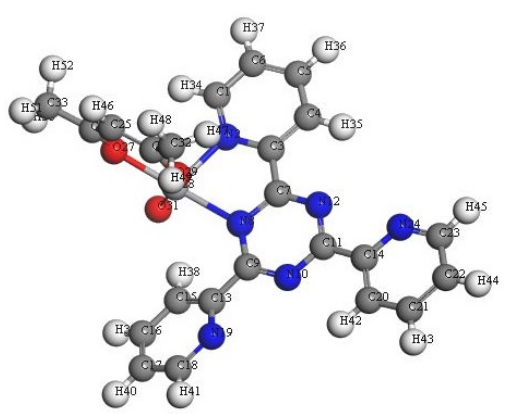

(a)

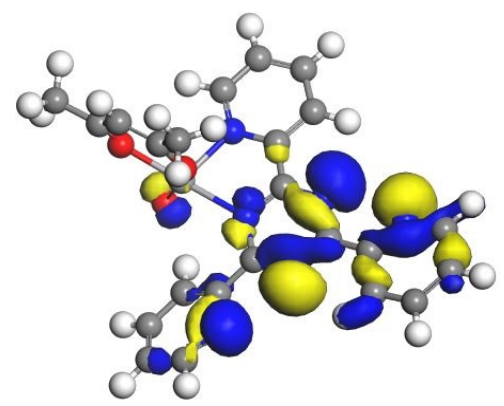

(c)

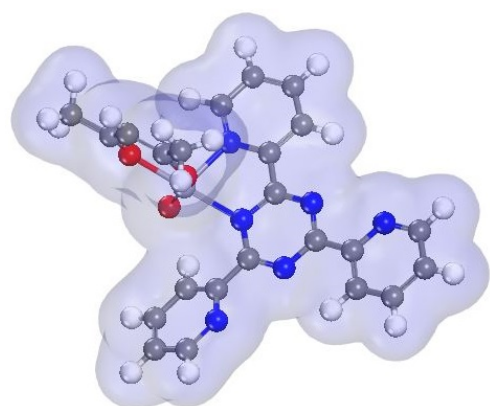

(b)

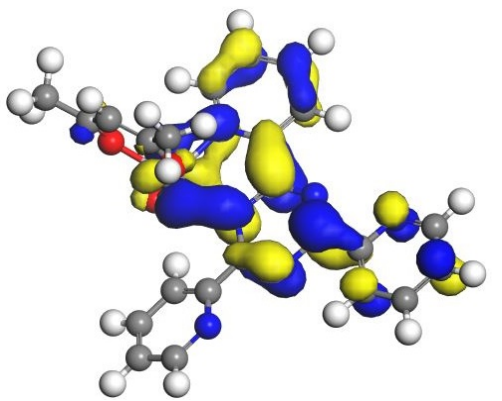

(d)

Figure S28. Molecular modeling of (a) $\left[\mathrm{VO}\left(\left(\mathbf{L}^{1}\right)\right)(2,4\right.$-pentadionate) $] \mathrm{Cl} \cdot 4 \mathrm{HCl}$, (b) electron density, (c) HOMO and (d) LUMO. 


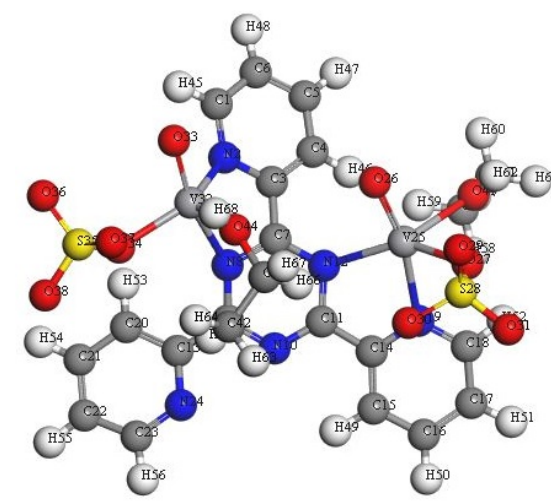

(a)

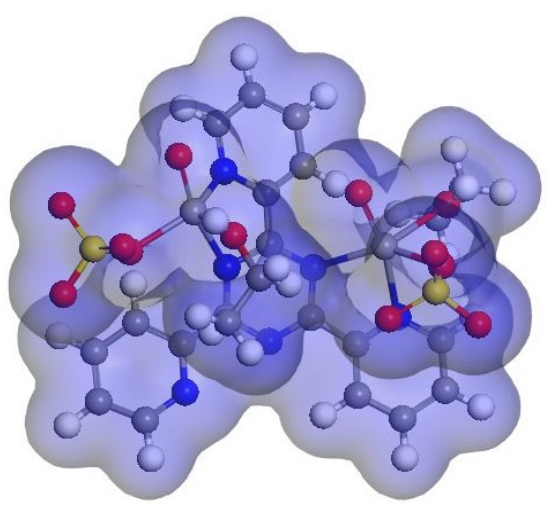

(b)

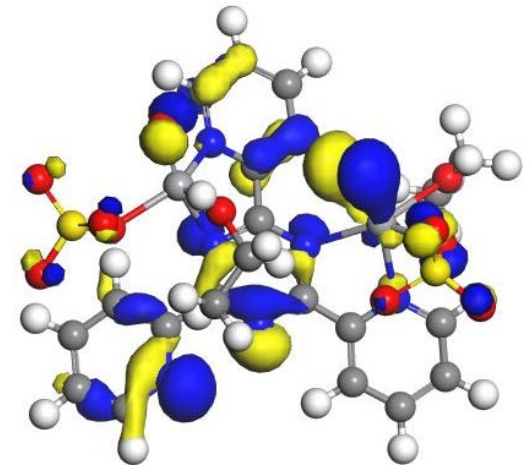

(c)

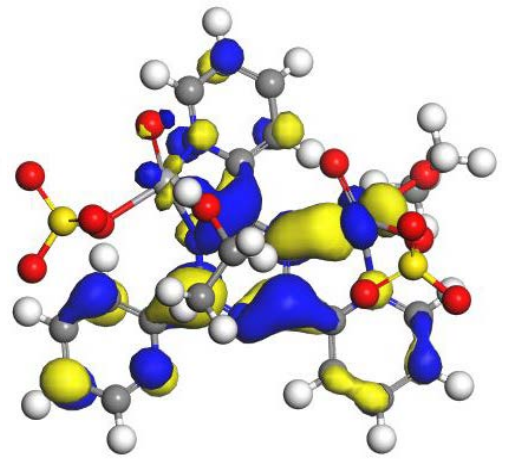

(d)

Figure S29. Molecular modeling of (a) $\left[\mathrm{V}_{2} \mathrm{O}_{2}\left(\left(\mathrm{~L}^{1}\right)\right)\left(\mathrm{SO}_{4}\right)_{2}(\mathrm{EtOH})_{5 / 2}\right]$, (b) electron density, (c) HOMO and (d) LUMO.

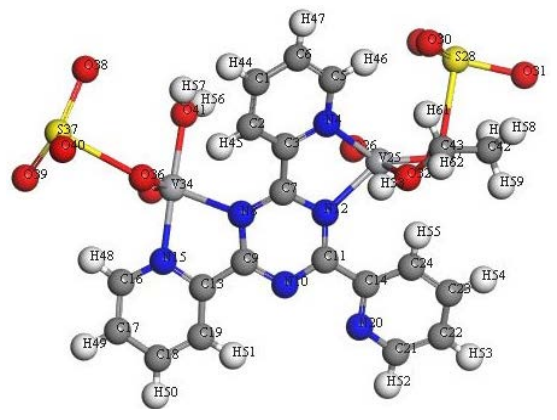

(a)

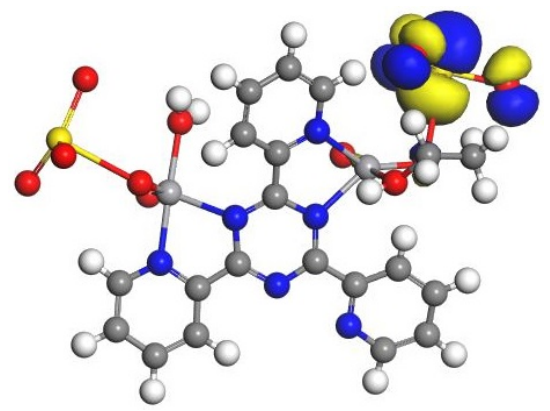

(c)

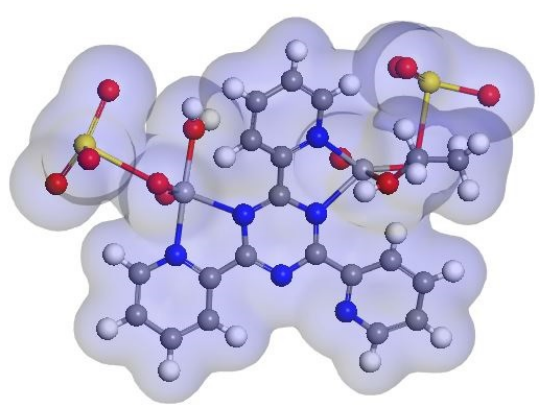

(b)

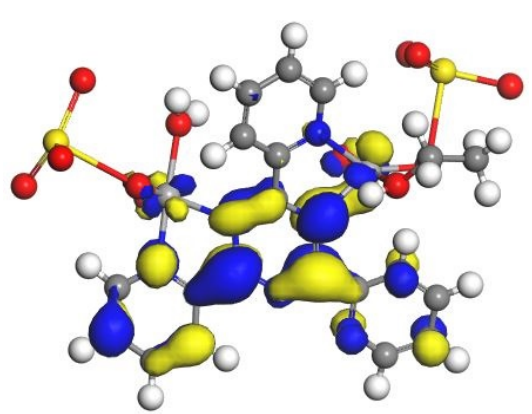

(d)

Figure S30. Molecular modeling of $(a)\left[\mathrm{V}_{2} \mathrm{O}_{2}\left(\left(\mathbf{L}^{1}\right)\right)\left(\mathrm{SO}_{4}\right)_{2}(\mathrm{EtOH})_{3 / 2}\left(\mathrm{H}_{2} \mathrm{O}\right)_{1 / 2}\right]$, (b) electron density, (c) HOMO and (d) LUMO. 


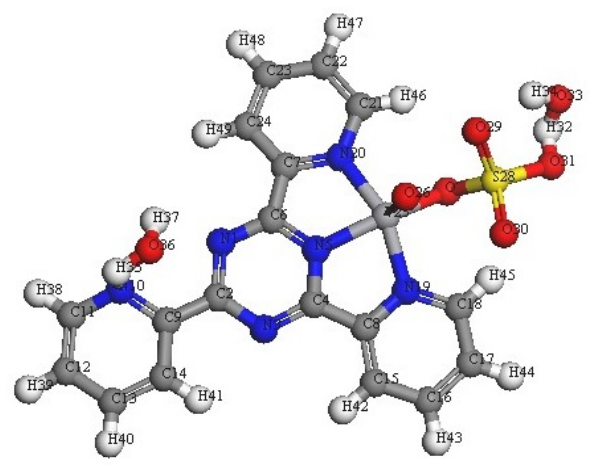

(a)

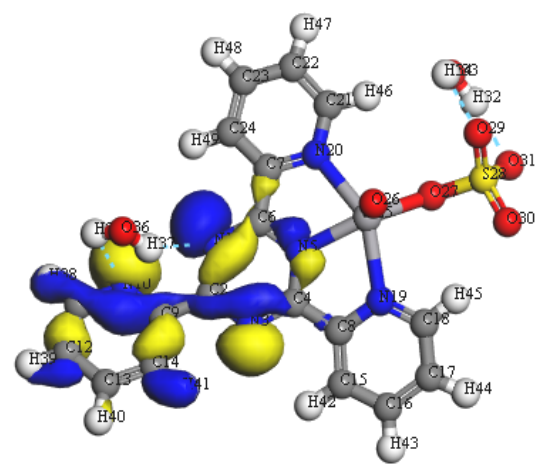

(c)

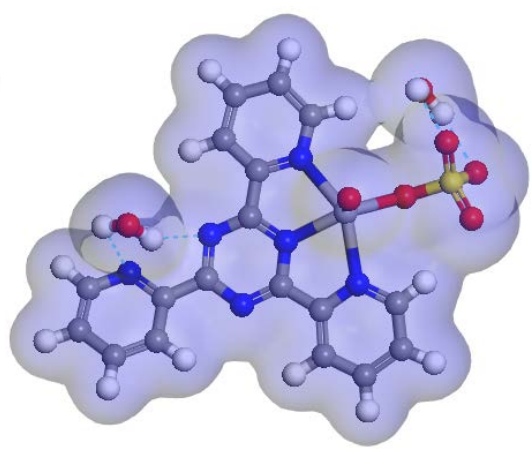

(b)

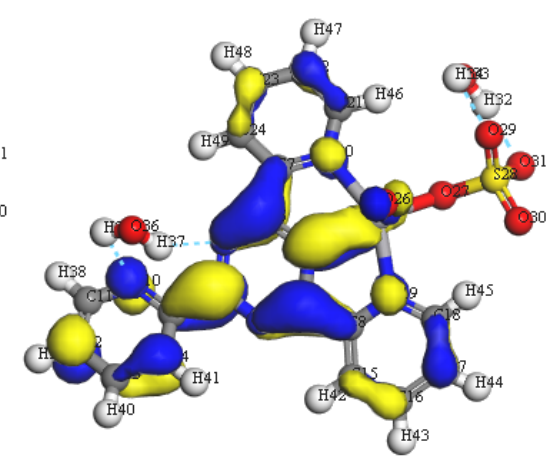

(d)

Figure S31. Molecular modeling of (a) $\left[\mathrm{VO}\left(\left(\mathrm{L}^{1}\right)\right) \mathrm{SO}_{4}\left(\mathrm{H}_{2} \mathrm{O}\right)_{3 / 2}\right] \cdot 2.5 \mathrm{H}_{2} \mathrm{O}$, (b) electron density, (c) HOMO and (d) LUMO.

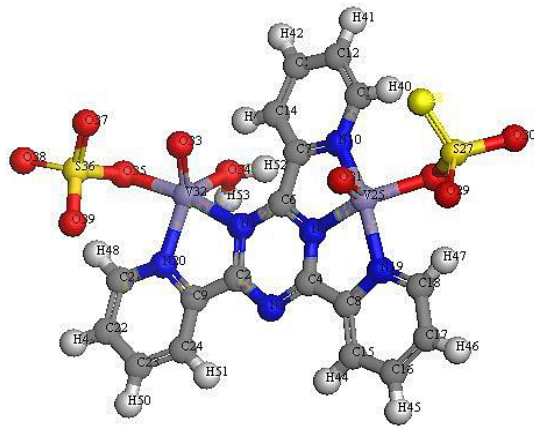

(a)

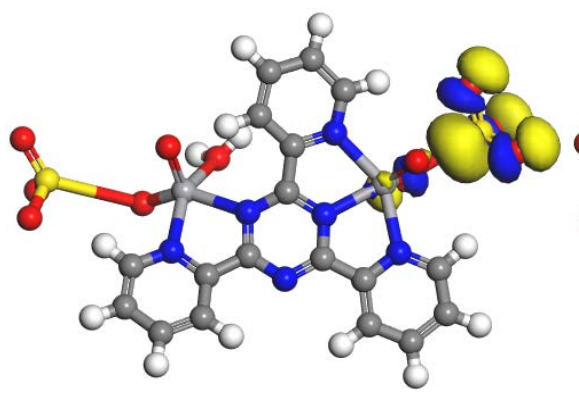

(c)

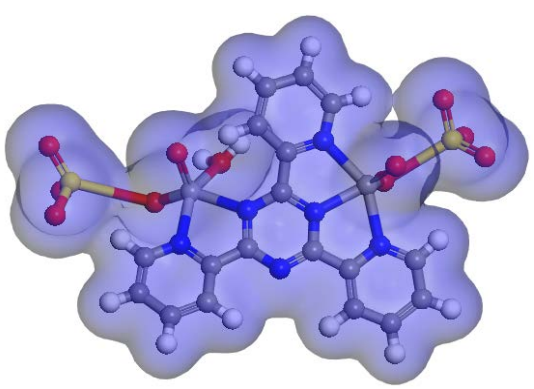

(b)

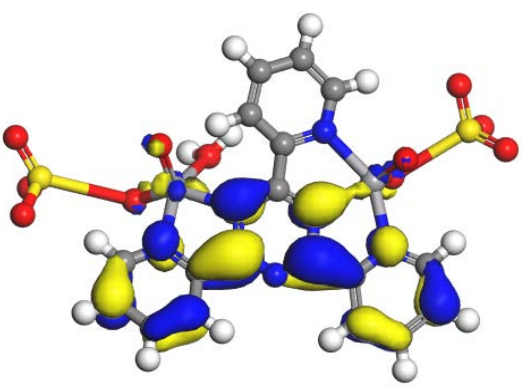

(d)

Figure S32. Molecular modeling of (a) $\left[\mathrm{V}_{2} \mathrm{O}_{2}\left(\left(\mathbf{L}^{1}\right)\right)\left(\mathrm{SO}_{4}\right)_{2}\left(\mathrm{H}_{2} \mathrm{O}\right)\right] \cdot \mathrm{H}_{2} \mathrm{O}$, (b) electron density, (c) HOMO and (d) LUMO. 
Table S1. Bonds lengths $(\AA)$ of $\left(\mathbf{L}^{\mathbf{1}}\right)$ using DFT-method from $\mathrm{DMOL}^{3}$ calculations.

\begin{tabular}{cccccc}
\hline Bond & Length $(\AA)$ & Bond & Length $(\AA)$ & Bond & Length $(\AA)$ \\
\hline $\mathrm{C}(24)-\mathrm{H}(36)$ & 1.087 & $\mathrm{~N}(15)-\mathrm{C}(16)$ & 1.339 & $\mathrm{C}(6)-\mathrm{C}(7)$ & 1.496 \\
$\mathrm{C}(23)-\mathrm{H}(35)$ & 1.092 & $\mathrm{C}(13)-\mathrm{H}(28)$ & 1.093 & $\mathrm{~N}(5)-\mathrm{C}(6)$ & 1.346 \\
$\mathrm{C}(23)-\mathrm{C}(24)$ & 1.396 & $\mathrm{C}(13)-\mathrm{N}(14)$ & 1.339 & $\mathrm{C}(4)-\mathrm{C}(9)$ & 1.497 \\
$\mathrm{C}(22)-\mathrm{H}(34)$ & 1.092 & $\mathrm{C}(12)-\mathrm{H}(27)$ & 1.089 & $\mathrm{C}(4)-\mathrm{N}(5)$ & 1.345 \\
$\mathrm{C}(22)-\mathrm{C}(23)$ & 1.399 & $\mathrm{C}(12)-\mathrm{C}(13)$ & 1.404 & $\mathrm{~N}(3)-\mathrm{C}(4)$ & 1.352 \\
$\mathrm{C}(21)-\mathrm{H}(33)$ & 1.094 & $\mathrm{C}(11)-\mathrm{H}(26)$ & 1.092 & $\mathrm{C}(2)-\mathrm{C}(8)$ & 1.496 \\
$\mathrm{C}(21)-\mathrm{C}(22)$ & 1.406 & $\mathrm{C}(11)-\mathrm{C}(12)$ & 1.399 & $\mathrm{C}(2)-\mathrm{N}(3)$ & 1.35 \\
$\mathrm{~N}(20)-\mathrm{C}(21)$ & 1.339 & $\mathrm{C}(10)-\mathrm{H}(25)$ & 1.087 & $\mathrm{C}(6)-\mathrm{N}(1)$ & 1.351 \\
$\mathrm{C}(19)-\mathrm{H}(32)$ & 1.087 & $\mathrm{C}(10)-\mathrm{C}(11)$ & 1.398 & $\mathrm{~N}(1)-\mathrm{C}(2)$ & 1.343 \\
$\mathrm{C}(18)-\mathrm{H}(31)$ & 1.092 & $\mathrm{~N}(14)-\mathrm{C}(9)$ & 1.35 & $\mathrm{C}(16)-\mathrm{C}(17)$ & 1.403 \\
$\mathrm{C}(18)-\mathrm{C}(19)$ & 1.397 & $\mathrm{C}(9)-\mathrm{C}(10)$ & 1.407 & $\mathrm{C}(7)-\mathrm{N}(20)$ & 1.35 \\
$\mathrm{C}(17)-\mathrm{H}(30)$ & 1.089 & $\mathrm{C}(19)-\mathrm{C}(8)$ & 1.406 & $\mathrm{C}(16)-\mathrm{H}(29)$ & 1.093 \\
$\mathrm{C}(17)-\mathrm{C}(18)$ & 1.399 & $\mathrm{C}(8)-\mathrm{N}(15)$ & 1.351 & $\mathrm{C}(24)-\mathrm{C}(7)$ & 1.407
\end{tabular}

Table S2. Bonds angles $\left({ }^{\circ}\right)$ of $\left(\mathbf{L}^{\mathbf{1}}\right)$ using DFT-method from DMOL ${ }^{3}$ calculations.

\begin{tabular}{|c|c|c|c|c|c|}
\hline Angle & Degree $\left({ }^{\circ}\right)$ & Angle & Degree $\left({ }^{\circ}\right)$ & Angle & Degree $\left({ }^{\circ}\right)$ \\
\hline $\mathrm{H}(36)-\mathrm{C}(24)-\mathrm{C}(23)$ & 123.136 & $\mathrm{C}(22)-\mathrm{C}(21)-\mathrm{N}(20)$ & 124.33 & $\mathrm{H}(29)-\mathrm{C}(16)-\mathrm{C}(17)$ & 120.469 \\
\hline $\mathrm{H}(36)-\mathrm{C}(24)-\mathrm{C}(7)$ & 118.205 & $\mathrm{C}(21)-\mathrm{N}(20)-\mathrm{C}(7)$ & 116.936 & $\mathrm{H}(29)-\mathrm{C}(16)-\mathrm{N}(15)$ & 115.357 \\
\hline$C(23)-C(24)-C(7)$ & 118.658 & $\mathrm{H}(32)-\mathrm{C}(19)-\mathrm{C}(18)$ & 122.169 & $\mathrm{C}(17)-\mathrm{C}(16)-\mathrm{N}(15)$ & 124.174 \\
\hline $\mathrm{H}(35)-\mathrm{C}(23)-\mathrm{C}(24)$ & 119.919 & $\mathrm{H}(32)-\mathrm{C}(19)-\mathrm{C}(8)$ & 118.861 & $\mathrm{C}(16)-\mathrm{N}(15)-\mathrm{C}(8)$ & 117.107 \\
\hline $\mathrm{H}(35)-\mathrm{C}(23)-\mathrm{C}(22)$ & 121.317 & $\mathrm{C}(18)-\mathrm{C}(19)-\mathrm{C}(8)$ & 118.97 & $\mathrm{C}(13)-\mathrm{N}(14)-\mathrm{C}(9)$ & 117.213 \\
\hline $\mathrm{C}(24)-\mathrm{C}(23)-\mathrm{C}(22)$ & 118.764 & $\mathrm{H}(31)-\mathrm{C}(18)-\mathrm{C}(19)$ & 120.715 & $\mathrm{H}(28)-\mathrm{C}(13)-\mathrm{N}(14)$ & 115.363 \\
\hline $\mathrm{H}(34)-\mathrm{C}(22)-\mathrm{C}(23)$ & 121.501 & $\mathrm{H}(31)-\mathrm{C}(18)-\mathrm{C}(17)$ & 120.896 & $\mathrm{H}(28)-\mathrm{C}(13)-\mathrm{C}(12)$ & 120.497 \\
\hline $\mathrm{H}(34)-\mathrm{C}(22)-\mathrm{C}(21)$ & 120.511 & $\mathrm{C}(19)-\mathrm{C}(18)-\mathrm{C}(17)$ & 118.389 & $\mathrm{~N}(14)-\mathrm{C}(13)-\mathrm{C}(12)$ & 124.14 \\
\hline $\mathrm{C}(23)-\mathrm{C}(22)-\mathrm{C}(21)$ & 117.988 & $\mathrm{H}(30)-\mathrm{C}(17)-\mathrm{C}(18)$ & 121.32 & $\mathrm{H}(27)-\mathrm{C}(12)-\mathrm{C}(13)$ & 120.281 \\
\hline $\mathrm{H}(33)-\mathrm{C}(21)-\mathrm{C}(22)$ & 120.077 & $\mathrm{H}(30)-\mathrm{C}(17)-\mathrm{C}(16)$ & 120.385 & $\mathrm{H}(27)-\mathrm{C}(12)-\mathrm{C}(11)$ & 121.439 \\
\hline $\mathrm{H}(33)-\mathrm{C}(21)-\mathrm{N}(20)$ & 115.593 & $\mathrm{C}(18)-\mathrm{C}(17)-\mathrm{C}(16)$ & 118.296 & $\mathrm{C}(13)-\mathrm{C}(12)-\mathrm{C}(11)$ & 118.28 \\
\hline $\mathrm{H}(26)-\mathrm{C}(11)-\mathrm{C}(12)$ & 120.915 & $\mathrm{~N}(15)-\mathrm{C}(8)-\mathrm{C}(2)$ & 117.089 & $\mathrm{C}(9)-\mathrm{C}(4)-\mathrm{N}(5)$ & 118.142 \\
\hline $\mathrm{H}(26)-\mathrm{C}(11)-\mathrm{C}(10)$ & 120.662 & $\mathrm{C}(24)-\mathrm{C}(7)-\mathrm{N}(20)$ & 123.323 & $\mathrm{C}(9)-\mathrm{C}(4)-\mathrm{N}(3)$ & 116.555 \\
\hline $\mathrm{C}(12)-\mathrm{C}(11)-\mathrm{C}(10)$ & 118.423 & $C(24)-C(7)-C(6)$ & 118.806 & $\mathrm{~N}(5)-\mathrm{C}(4)-\mathrm{N}(3)$ & 125.303 \\
\hline $\mathrm{H}(25)-\mathrm{C}(10)-\mathrm{C}(11)$ & 122.01 & $N(20)-C(7)-C(6)$ & 117.87 & $\mathrm{C}(4)-\mathrm{N}(3)-\mathrm{C}(2)$ & 115.003 \\
\hline $\mathrm{H}(25)-\mathrm{C}(10)-\mathrm{C}(9)$ & 119.06 & $\mathrm{C}(7)-\mathrm{C}(6)-\mathrm{N}(5)$ & 118.503 & $\mathrm{C}(8)-\mathrm{C}(2)-\mathrm{N}(3)$ & 116.897 \\
\hline $\mathrm{C}(11)-\mathrm{C}(10)-\mathrm{C}(9)$ & 118.93 & $\mathrm{C}(7)-\mathrm{C}(6)-\mathrm{N}(1)$ & 115.844 & $\mathrm{C}(8)-\mathrm{C}(2)-\mathrm{N}(1)$ & 118.259 \\
\hline $\mathrm{N}(14)-\mathrm{C}(9)-\mathrm{C}(10)$ & 123.013 & $\mathrm{~N}(5)-\mathrm{C}(6)-\mathrm{N}(1)$ & 125.653 & $\mathrm{~N}(3)-\mathrm{C}(2)-\mathrm{N}(1)$ & 124.844 \\
\hline $\mathrm{N}(14)-\mathrm{C}(9)-\mathrm{C}(4)$ & 116.981 & $\mathrm{C}(6)-\mathrm{N}(5)-\mathrm{C}(4)$ & 114.353 & $\mathrm{C}(6)-\mathrm{N}(1)-\mathrm{C}(2)$ & 114.844 \\
\hline $\mathrm{C}(10)-\mathrm{C}(9)-\mathrm{C}(4)$ & 120.006 & $C(19)-C(8)-C(2)$ & 119.847 & $\mathrm{C}(19)-\mathrm{C}(8)-\mathrm{N}(15)$ & 123.064 \\
\hline
\end{tabular}


Table S3. Bonds lengths $(\AA)$ of $\left[\mathrm{VO}\left(\left(\mathrm{L}^{1}\right)\right)(2,4\right.$-pentadionate $\left.)\right] \mathrm{Cl} \cdot 4 \mathrm{HCl}$ using DFT-method from $\mathrm{DMOL}^{3}$ calculations.

\begin{tabular}{cccccccc}
\hline Bond & Length $(\AA)$ & Bond & Length $(\AA)$ & Bond & Length $(\AA)$ & Bond & Length $(\AA)$ \\
\hline $\mathrm{C}(33)-\mathrm{H}(51)$ & 1.109 & $\mathrm{C}(21)-\mathrm{C}(22)$ & 1.426 & $\mathrm{~N}(8)-\mathrm{V}(28)$ & 2.228 & $\mathrm{C}(22)-\mathrm{H}(44)$ & 1.097 \\
$\mathrm{C}(33)-\mathrm{H}(50)$ & 1.106 & $\mathrm{C}(20)-\mathrm{H}(42)$ & 1.095 & $\mathrm{~N}(8)-\mathrm{C}(9)$ & 1.41 & $\mathrm{C}(22)-\mathrm{C}(23)$ & 1.433 \\
$\mathrm{C}(32)-\mathrm{H}(49)$ & 1.112 & $\mathrm{C}(20)-\mathrm{C}(21)$ & 1.423 & $\mathrm{~N}(12)-\mathrm{C}(7)$ & 1.378 & $\mathrm{C}(21)-\mathrm{H}(43)$ & 1.098 \\
$\mathrm{C}(32)-\mathrm{H}(48)$ & 1.107 & $\mathrm{C}(18)-\mathrm{H}(41)$ & 1.096 & $\mathrm{C}(7)-\mathrm{N}(8)$ & 1.414 & $\mathrm{~N}(10)-\mathrm{C}(11)$ & 1.388 \\
$\mathrm{C}(32)-\mathrm{H}(47)$ & 1.113 & $\mathrm{C}(18)-\mathrm{N}(19)$ & 1.372 & $\mathrm{C}(6)-\mathrm{H}(37)$ & 1.096 & $\mathrm{C}(9)-\mathrm{C}(13)$ & 1.462 \\
$\mathrm{C}(30)-\mathrm{C}(32)$ & 1.511 & $\mathrm{C}(17)-\mathrm{H}(40)$ & 1.098 & $\mathrm{C}(5)-\mathrm{H}(36)$ & 1.097 & $\mathrm{C}(9)-\mathrm{N}(10)$ & 1.38 \\
$\mathrm{O}(29)-\mathrm{C}(30)$ & 1.357 & $\mathrm{C}(17)-\mathrm{C}(18)$ & 1.429 & $\mathrm{C}(5)-\mathrm{C}(6)$ & 1.429 & $\mathrm{C}(23)-\mathrm{N}(24)$ & 1.371 \\
$\mathrm{~V}(28)-\mathrm{O}(31)$ & 1.889 & $\mathrm{C}(16)-\mathrm{H}(39)$ & 1.098 & $\mathrm{C}(4)-\mathrm{H}(35)$ & 1.096 & $\mathrm{C}(11)-\mathrm{N}(12)$ & 1.388 \\
$\mathrm{~V}(28)-\mathrm{O}(29)$ & 2.132 & $\mathrm{C}(16)-\mathrm{C}(17)$ & 1.426 & $\mathrm{C}(4)-\mathrm{C}(5)$ & 1.423 & $\mathrm{C}(23)-\mathrm{H}(45)$ & 1.096 \\
$\mathrm{O}(27)-\mathrm{V}(28)$ & 2.099 & $\mathrm{C}(15)-\mathrm{H}(38)$ & 1.096 & $\mathrm{C}(3)-\mathrm{C}(7)$ & 1.454 & $\mathrm{C}(11)-\mathrm{C}(14)$ & 1.456 \\
$\mathrm{C}(26)-\mathrm{C}(33)$ & 1.514 & $\mathrm{C}(15)-\mathrm{C}(16)$ & 1.424 & $\mathrm{C}(3)-\mathrm{C}(4)$ & 1.436 & $\mathrm{C}(1)-\mathrm{N}(2)$ & 1.389 \\
$\mathrm{C}(26)-\mathrm{O}(27)$ & 1.359 & $\mathrm{~N}(24)-\mathrm{C}(14)$ & 1.39 & $\mathrm{~N}(2)-\mathrm{V}(28)$ & 2.159 & $\mathrm{C}(6)-\mathrm{C}(1)$ & 1.424 \\
$\mathrm{C}(25)-\mathrm{H}(46)$ & 1.097 & $\mathrm{C}(14)-\mathrm{C}(20)$ & 1.446 & $\mathrm{~N}(2)-\mathrm{C}(3)$ & 1.409 & $\mathrm{C}(13)-\mathrm{C}(15)$ & 1.442 \\
$\mathrm{C}(30)-\mathrm{C}(25)$ & 1.435 & $\mathrm{~N}(19)-\mathrm{C}(13)$ & 1.392 & $\mathrm{C}(1)-\mathrm{H}(34)$ & 1.094 & $\mathrm{C}(25)-\mathrm{C}(26)$ & 1.438 \\
\hline
\end{tabular}

Table S4. Bonds angles $\left({ }^{\circ}\right)$ of $\left[\mathrm{VO}\left(\left(\mathrm{L}^{1}\right)\right)(2,4\right.$-pentadionate $\left.)\right] \mathrm{Cl} \cdot 4 \mathrm{HCl}$ using DFT-method from $\mathrm{DMOL}^{3}$ calculations.

\begin{tabular}{|c|c|c|c|c|c|}
\hline Angle & Degree $\left({ }^{\circ}\right)$ & Angle & Degree $\left({ }^{\circ}\right)$ & Angle & Degree $\left({ }^{\circ}\right)$ \\
\hline $\mathrm{H}(37)-\mathrm{C}(6)-\mathrm{C}(1)$ & 119.308 & $\mathrm{H}(35)-\mathrm{C}(4)-\mathrm{C}(5)$ & 122.022 & $\mathrm{C}(4)-\mathrm{C}(3)-\mathrm{N}(2)$ & 120.585 \\
\hline$C(5)-C(6)-C(1)$ & 119.363 & $\mathrm{H}(35)-\mathrm{C}(4)-\mathrm{C}(3)$ & 118.787 & $\mathrm{~V}(28)-\mathrm{N}(2)-\mathrm{C}(3)$ & 115.096 \\
\hline $\mathrm{H}(36)-\mathrm{C}(5)-\mathrm{C}(6)$ & 120.271 & $C(5)-C(4)-C(3)$ & 119.188 & $\mathrm{~V}(28)-\mathrm{N}(2)-\mathrm{C}(1)$ & 125.092 \\
\hline $\mathrm{H}(36)-\mathrm{C}(5)-\mathrm{C}(4)$ & 120.089 & $\mathrm{C}(7)-\mathrm{C}(3)-\mathrm{C}(4)$ & 123.145 & $\mathrm{C}(3)-\mathrm{N}(2)-\mathrm{C}(1)$ & 119.805 \\
\hline$C(6)-C(5)-C(4)$ & 119.629 & $\mathrm{C}(7)-\mathrm{C}(3)-\mathrm{N}(2)$ & 116.261 & $\mathrm{H}(34)-\mathrm{C}(1)-\mathrm{C}(6)$ & 122.591 \\
\hline $\mathrm{H}(52)-\mathrm{C}(33)-\mathrm{H}(51)$ & 107.597 & $\mathrm{O}(29)-\mathrm{V}(28)-\mathrm{O}(27)$ & 80.397 & $\mathrm{H}(43)-\mathrm{C}(21)-\mathrm{C}(22)$ & 120.667 \\
\hline $\mathrm{H}(52)-\mathrm{C}(33)-\mathrm{H}(50)$ & 107.628 & $\mathrm{O}(29)-\mathrm{V}(28)-\mathrm{N}(8)$ & 83.836 & $\mathrm{H}(43)-\mathrm{C}(21)-\mathrm{C}(20)$ & 119.761 \\
\hline $\mathrm{H}(52)-\mathrm{C}(33)-\mathrm{C}(26)$ & 111.383 & $\mathrm{O}(29)-\mathrm{V}(28)-\mathrm{N}(2)$ & 96.459 & $\mathrm{C}(22)-\mathrm{C}(21)-\mathrm{C}(20)$ & 119.559 \\
\hline $\mathrm{H}(51)-\mathrm{C}(33)-\mathrm{H}(50)$ & 109.117 & $\mathrm{O}(27)-\mathrm{V}(28)-\mathrm{N}(8)$ & 164.163 & $\mathrm{H}(42)-\mathrm{C}(20)-\mathrm{C}(21)$ & 121.619 \\
\hline $\mathrm{H}(51)-\mathrm{C}(33)-\mathrm{C}(26)$ & 111.335 & $\mathrm{O}(27)-\mathrm{V}(28)-\mathrm{N}(2)$ & 105.823 & $\mathrm{H}(42)-\mathrm{C}(20)-\mathrm{C}(14)$ & 118.636 \\
\hline $\mathrm{H}(50)-\mathrm{C}(33)-\mathrm{C}(26)$ & 109.672 & $\mathrm{~N}(8)-\mathrm{V}(28)-\mathrm{N}(2)$ & 77.359 & $C(21)-C(20)-C(14)$ & 119.746 \\
\hline $\mathrm{H}(49)-\mathrm{C}(32)-\mathrm{H}(48)$ & 108.285 & $\mathrm{~V}(28)-\mathrm{O}(27)-\mathrm{C}(26)$ & 135.836 & $\mathrm{C}(18)-\mathrm{N}(19)-\mathrm{C}(13)$ & 120.954 \\
\hline $\mathrm{H}(49)-\mathrm{C}(32)-\mathrm{H}(47)$ & 106.523 & $\mathrm{C}(33)-\mathrm{C}(26)-\mathrm{O}(27)$ & 116.77 & $\mathrm{H}(41)-\mathrm{C}(18)-\mathrm{N}(19)$ & 116.458 \\
\hline $\mathrm{H}(49)-\mathrm{C}(32)-\mathrm{C}(30)$ & 110.681 & $\mathrm{C}(33)-\mathrm{C}(26)-\mathrm{C}(25)$ & 121.363 & $\mathrm{H}(41)-\mathrm{C}(18)-\mathrm{C}(17)$ & 121.876 \\
\hline $\mathrm{H}(48)-\mathrm{C}(32)-\mathrm{H}(47)$ & 108.741 & $\mathrm{O}(27)-\mathrm{C}(26)-\mathrm{C}(25)$ & 121.832 & N(19)-C(18)-C(17) & 121.666 \\
\hline $\mathrm{H}(48)-\mathrm{C}(32)-\mathrm{C}(30)$ & 111.441 & $\mathrm{H}(46)-\mathrm{C}(25)-\mathrm{C}(30)$ & 117.513 & $\mathrm{H}(40)-\mathrm{C}(17)-\mathrm{C}(18)$ & 119.892 \\
\hline $\mathrm{H}(47)-\mathrm{C}(32)-\mathrm{C}(30)$ & 111 & $\mathrm{H}(46)-\mathrm{C}(25)-\mathrm{C}(26)$ & 117.684 & $\mathrm{H}(40)-\mathrm{C}(17)-\mathrm{C}(16)$ & 121.469 \\
\hline $\mathrm{C}(32)-\mathrm{C}(30)-\mathrm{O}(29)$ & 116.538 & $C(30)-C(25)-C(26)$ & 124.795 & $\mathrm{C}(18)-\mathrm{C}(17)-\mathrm{C}(16)$ & 118.633 \\
\hline$C(32)-C(30)-C(25)$ & 122.351 & $\mathrm{C}(23)-\mathrm{N}(24)-\mathrm{C}(14)$ & 120.997 & H(39)-C(16)-C(17) & 120.884 \\
\hline
\end{tabular}




\section{Continued}

\begin{tabular}{cccccc}
\hline $\mathrm{O}(29)-\mathrm{C}(30)-\mathrm{C}(25)$ & 121.105 & $\mathrm{H}(45)-\mathrm{C}(23)-\mathrm{N}(24)$ & 116.594 & $\mathrm{H}(39)-\mathrm{C}(16)-\mathrm{C}(15)$ & 119.657 \\
$\mathrm{C}(30)-\mathrm{O}(29)-\mathrm{V}(28)$ & 135.272 & $\mathrm{H}(45)-\mathrm{C}(23)-\mathrm{C}(22)$ & 121.533 & $\mathrm{C}(17)-\mathrm{C}(16)-\mathrm{C}(15)$ & 119.447 \\
$\mathrm{O}(31)-\mathrm{V}(28)-\mathrm{O}(29)$ & 161.774 & $\mathrm{~N}(24)-\mathrm{C}(23)-\mathrm{C}(22)$ & 121.873 & $\mathrm{H}(38)-\mathrm{C}(15)-\mathrm{C}(16)$ & 120.374 \\
$\mathrm{O}(31)-\mathrm{V}(28)-\mathrm{O}(27)$ & 92.993 & $\mathrm{H}(44)-\mathrm{C}(22)-\mathrm{C}(23)$ & 119.868 & $\mathrm{H}(38)-\mathrm{C}(15)-\mathrm{C}(13)$ & 119.96 \\
$\mathrm{O}(31)-\mathrm{V}(28)-\mathrm{N}(8)$ & 101.62 & $\mathrm{H}(44)-\mathrm{C}(22)-\mathrm{C}(21)$ & 121.76 & $\mathrm{C}(16)-\mathrm{C}(15)-\mathrm{C}(13)$ & 119.621 \\
$\mathrm{O}(31)-\mathrm{V}(28)-\mathrm{N}(2)$ & 101.694 & $\mathrm{C}(23)-\mathrm{C}(22)-\mathrm{C}(21)$ & 118.362 & $\mathrm{~N}(24)-\mathrm{C}(14)-\mathrm{C}(20)$ & 119.458 \\
$\mathrm{H}(34)-\mathrm{C}(1)-\mathrm{N}(2)$ & 116.078 & $\mathrm{C}(11)-\mathrm{N}(10)-\mathrm{C}(9)$ & 120.1 & $\mathrm{~N}(19)-\mathrm{C}(13)-\mathrm{C}(9)$ & 118.065 \\
$\mathrm{C}(6)-\mathrm{C}(1)-\mathrm{N}(2)$ & 121.32 & $\mathrm{C}(13)-\mathrm{C}(9)-\mathrm{N}(10)$ & 119.362 & $\mathrm{C}(15)-\mathrm{C}(13)-\mathrm{C}(9)$ & 122.375 \\
$\mathrm{H}(37)-\mathrm{C}(6)-\mathrm{C}(5)$ & 121.317 & $\mathrm{C}(13)-\mathrm{C}(9)-\mathrm{N}(8)$ & 119.569 & $\mathrm{C}(11)-\mathrm{N}(12)-\mathrm{C}(7)$ & 119.039 \\
$\mathrm{~N}(8)-\mathrm{C}(7)-\mathrm{C}(3)$ & 117.697 & $\mathrm{~N}(10)-\mathrm{C}(9)-\mathrm{N}(8)$ & 121.063 & $\mathrm{C}(14)-\mathrm{C}(11)-\mathrm{N}(12)$ & 120.979 \\
$\mathrm{~N}(12)-\mathrm{C}(7)-\mathrm{C}(3)$ & 120.033 & $\mathrm{~V}(28)-\mathrm{N}(8)-\mathrm{C}(9)$ & 129.609 & $\mathrm{C}(14)-\mathrm{C}(11)-\mathrm{N}(10)$ & 118.57 \\
$\mathrm{~N}(24)-\mathrm{C}(14)-\mathrm{C}(11)$ & 118.742 & $\mathrm{~V}(28)-\mathrm{N}(8)-\mathrm{C}(7)$ & 111.196 & $\mathrm{~N}(12)-\mathrm{C}(11)-\mathrm{N}(10)$ & 120.441 \\
$\mathrm{C}(20)-\mathrm{C}(14)-\mathrm{C}(11)$ & 121.798 & $\mathrm{C}(9)-\mathrm{N}(8)-\mathrm{C}(7)$ & 116.667 & $\mathrm{~N}(12)-\mathrm{C}(7)-\mathrm{N}(8)$ & 122.221 \\
$\mathrm{~N}(19)-\mathrm{C}(13)-\mathrm{C}(15)$ & 119.547 & & & \\
\hline
\end{tabular}

Table S5. Bonds lengths $(\AA)$ of $\left[\mathrm{V}_{2} \mathrm{O}_{2}\left(\left(\mathrm{~L}^{1}\right)\right)\left(\mathrm{SO}_{4}\right)_{2}(\mathrm{EtOH})_{5 / 2}\right]$ using DFT-method from $\mathrm{DMOL}^{3}$ calculations.

\begin{tabular}{|c|c|c|c|c|c|c|c|}
\hline Bond & Length $(\AA)$ & Bond & Length $(\AA)$ & Bond & Length $(\AA)$ & Bond & Length ( $\AA$ ) \\
\hline $\mathrm{O}(44)-\mathrm{H}(68)$ & 0.988 & $\mathrm{O}(44)-\mathrm{V}(32)$ & 2.315 & $\mathrm{C}(18)-\mathrm{N}(19)$ & 1.368 & $\mathrm{C}(7)-\mathrm{N}(8)$ & 1.392 \\
\hline $\mathrm{C}(43)-\mathrm{H}(67)$ & 1.106 & $\mathrm{~V}(32)-\mathrm{O}(34)$ & 2.132 & $\mathrm{C}(17)-\mathrm{H}(51)$ & 1.097 & $\mathrm{C}(6)-\mathrm{H}(48)$ & 1.095 \\
\hline $\mathrm{C}(43)-\mathrm{H}(66)$ & 1.1 & $\mathrm{~V}(32)-\mathrm{O}(33)$ & 1.833 & $\mathrm{C}(17)-\mathrm{C}(18)$ & 1.412 & $\mathrm{C}(5)-\mathrm{H}(47)$ & 1.095 \\
\hline $\mathrm{C}(43)-\mathrm{O}(44)$ & 1.469 & $\mathrm{~S}(28)-\mathrm{O}(31)$ & 1.507 & $\mathrm{C}(16)-\mathrm{H}(50)$ & 1.098 & $\mathrm{C}(5)-\mathrm{C}(6)$ & 1.416 \\
\hline $\mathrm{C}(42)-\mathrm{H}(65)$ & 1.106 & $\mathrm{~S}(28)-\mathrm{O}(30)$ & 1.519 & $\mathrm{C}(16)-\mathrm{C}(17)$ & 1.419 & $\mathrm{C}(4)-\mathrm{H}(46)$ & 1.093 \\
\hline $\mathrm{C}(42)-\mathrm{H}(64)$ & 1.106 & $\mathrm{~S}(28)-\mathrm{O}(29)$ & 1.51 & $\mathrm{C}(15)-\mathrm{H}(49)$ & 1.096 & $\mathrm{C}(4)-\mathrm{C}(5)$ & 1.411 \\
\hline $\mathrm{C}(42)-\mathrm{H}(63)$ & 1.108 & $\mathrm{O}(27)-\mathrm{S}(28)$ & 1.578 & $\mathrm{C}(15)-\mathrm{C}(16)$ & 1.412 & $\mathrm{C}(3)-\mathrm{C}(7)$ & 1.453 \\
\hline$C(42)-C(43)$ & 1.526 & $\mathrm{O}(41)-\mathrm{V}(25)$ & 2.373 & $\mathrm{~N}(19)-\mathrm{C}(14)$ & 1.385 & $\mathrm{C}(3)-\mathrm{C}(4)$ & 1.423 \\
\hline $\mathrm{O}(41)-\mathrm{H}(62)$ & 0.991 & $\mathrm{~V}(25)-\mathrm{O}(27)$ & 2.133 & $\mathrm{C}(14)-\mathrm{C}(15)$ & 1.427 & $\mathrm{~N}(2)-\mathrm{V}(32)$ & 2.225 \\
\hline $\mathrm{C}(40)-\mathrm{H}(61)$ & 1.109 & $\mathrm{~V}(25)-\mathrm{O}(26)$ & 1.839 & $\mathrm{~N}(24)-\mathrm{C}(13)$ & 1.369 & $\mathrm{~N}(2)-\mathrm{C}(3)$ & 1.391 \\
\hline $\mathrm{C}(40)-\mathrm{H}(60)$ & 1.111 & $\mathrm{C}(23)-\mathrm{H}(56)$ & 1.099 & $C(13)-C(20)$ & 1.432 & $\mathrm{C}(1)-\mathrm{H}(45)$ & 1.096 \\
\hline $\mathrm{C}(40)-\mathrm{O}(41)$ & 1.487 & $\mathrm{C}(23)-\mathrm{N}(24)$ & 1.349 & $N(12)-V(25)$ & 2.296 & $\mathrm{C}(6)-\mathrm{C}(1)$ & 1.413 \\
\hline C(39)-H(59) & 1.106 & $\mathrm{C}(22)-\mathrm{H}(55)$ & 1.095 & $\mathrm{C}(11)-\mathrm{C}(14)$ & 1.454 & $\mathrm{C}(1)-\mathrm{N}(2)$ & 1.368 \\
\hline $\mathrm{C}(39)-\mathrm{H}(58)$ & 1.106 & $C(22)-C(23)$ & 1.419 & $\mathrm{C}(11)-\mathrm{N}(12)$ & 1.391 & $\mathrm{O}(34)-\mathrm{S}(35)$ & 1.579 \\
\hline $\mathrm{C}(39)-\mathrm{H}(57)$ & 1.107 & $\mathrm{C}(21)-\mathrm{H}(54)$ & 1.095 & $\mathrm{~N}(10)-\mathrm{C}(11)$ & 1.351 & $\mathrm{C}(18)-\mathrm{H}(52)$ & 1.094 \\
\hline C(39)-C(40) & 1.521 & $\mathrm{C}(21)-\mathrm{C}(22)$ & 1.416 & $\mathrm{C}(9)-\mathrm{C}(13)$ & 1.462 & $\mathrm{~N}(12)-\mathrm{C}(7)$ & 1.379 \\
\hline $\mathrm{S}(35)-\mathrm{O}(38)$ & 1.512 & $\mathrm{C}(20)-\mathrm{H}(53)$ & 1.093 & $\mathrm{C}(9)-\mathrm{N}(10)$ & 1.359 & & \\
\hline $\mathrm{S}(35)-\mathrm{O}(37)$ & 1.519 & $C(20)-C(21)$ & 1.414 & $\mathrm{~N}(8)-\mathrm{V}(32)$ & 2.367 & & \\
\hline $\mathrm{S}(35)-\mathrm{O}(36)$ & 1.506 & $\mathrm{~N}(19)-\mathrm{V}(25)$ & 2.294 & $\mathrm{~N}(8)-\mathrm{C}(9)$ & 1.385 & & \\
\hline
\end{tabular}


Table S6. Bonds lengths $(\AA)$ of $\left[\mathrm{V}_{2} \mathrm{O}_{2}\left(\left(\mathbf{L}^{1}\right)\right)\left(\mathrm{SO}_{4}\right)_{2}(\mathrm{EtOH})_{5 / 2}\right]$ using DFT-method from $\mathrm{DMOL}^{3}$ calculations.

\begin{tabular}{|c|c|c|c|c|c|}
\hline Angle & Degree ( $\left.{ }^{\circ}\right)$ & Angle & Degree $\left({ }^{\circ}\right)$ & Angle & Degree $\left({ }^{\circ}\right)$ \\
\hline $\mathrm{H}(68)-\mathrm{O}(44)-\mathrm{C}(43)$ & 109.782 & $\mathrm{H}(61)-\mathrm{C}(40)-\mathrm{C}(39)$ & 112.154 & $\mathrm{O}(44)-\mathrm{V}(32)-\mathrm{N}(2)$ & 127.601 \\
\hline $\mathrm{H}(68)-\mathrm{O}(44)-\mathrm{V}(32)$ & 104.71 & $\mathrm{H}(60)-\mathrm{C}(40)-\mathrm{O}(41)$ & 108.02 & $\mathrm{O}(34)-\mathrm{V}(32)-\mathrm{O}(33)$ & 99.453 \\
\hline $\mathrm{C}(43)-\mathrm{O}(44)-\mathrm{V}(32)$ & 138.294 & $\mathrm{H}(60)-\mathrm{C}(40)-\mathrm{C}(39)$ & 111.056 & $\mathrm{O}(34)-\mathrm{V}(32)-\mathrm{N}(8)$ & 95.592 \\
\hline $\mathrm{H}(67)-\mathrm{C}(43)-\mathrm{H}(66)$ & 107.446 & $\mathrm{O}(41)-\mathrm{C}(40)-\mathrm{C}(39)$ & 109.439 & $\mathrm{O}(34)-\mathrm{V}(32)-\mathrm{N}(2)$ & 136.214 \\
\hline $\mathrm{H}(67)-\mathrm{C}(43)-\mathrm{O}(44)$ & 107.729 & H(59)-C(39)-H(58) & 108.165 & $\mathrm{O}(33)-\mathrm{V}(32)-\mathrm{N}(8)$ & 163.318 \\
\hline $\mathrm{H}(67)-\mathrm{C}(43)-\mathrm{C}(42)$ & 111.599 & H(59)-C(39)-H(57) & 107.899 & $\mathrm{O}(33)-\mathrm{V}(32)-\mathrm{N}(2)$ & 92.392 \\
\hline $\mathrm{H}(66)-\mathrm{C}(43)-\mathrm{O}(44)$ & 105.322 & H(59)-C(39)-C(40) & 111.439 & $\mathrm{~N}(8)-\mathrm{V}(32)-\mathrm{N}(2)$ & 71.635 \\
\hline $\mathrm{H}(66)-\mathrm{C}(43)-\mathrm{C}(42)$ & 111.293 & H(58)-C(39)-H(57) & 108.33 & $\mathrm{O}(31)-\mathrm{S}(28)-\mathrm{O}(30)$ & 111.454 \\
\hline $\mathrm{O}(44)-\mathrm{C}(43)-\mathrm{C}(42)$ & 113.086 & $\mathrm{H}(58)-\mathrm{C}(39)-\mathrm{C}(40)$ & 111.272 & $\mathrm{O}(31)-\mathrm{S}(28)-\mathrm{O}(29)$ & 111.279 \\
\hline $\mathrm{H}(65)-\mathrm{C}(42)-\mathrm{H}(64)$ & 108.107 & $\mathrm{H}(57)-\mathrm{C}(39)-\mathrm{C}(40)$ & 109.622 & $\mathrm{O}(31)-\mathrm{S}(28)-\mathrm{O}(27)$ & 107.626 \\
\hline $\mathrm{H}(65)-\mathrm{C}(42)-\mathrm{H}(63)$ & 108.06 & $\mathrm{O}(38)-\mathrm{S}(35)-\mathrm{O}(37)$ & 110.023 & $\mathrm{O}(30)-\mathrm{S}(28)-\mathrm{O}(29)$ & 110.915 \\
\hline $\mathrm{H}(65)-\mathrm{C}(42)-\mathrm{C}(43)$ & 111.485 & $\mathrm{O}(38)-\mathrm{S}(35)-\mathrm{O}(36)$ & 110.731 & $\mathrm{O}(30)-\mathrm{S}(28)-\mathrm{O}(27)$ & 106.521 \\
\hline $\mathrm{H}(64)-\mathrm{C}(42)-\mathrm{H}(63)$ & 108.295 & $\mathrm{O}(38)-\mathrm{S}(35)-\mathrm{O}(34)$ & 106.925 & $\mathrm{O}(29)-\mathrm{S}(28)-\mathrm{O}(27)$ & 108.84 \\
\hline $\mathrm{H}(64)-\mathrm{C}(42)-\mathrm{C}(43)$ & 111.666 & $\mathrm{O}(37)-\mathrm{S}(35)-\mathrm{O}(36)$ & 111.933 & $\mathrm{~S}(28)-\mathrm{O}(27)-\mathrm{V}(25)$ & 126.064 \\
\hline $\mathrm{H}(63)-\mathrm{C}(42)-\mathrm{C}(43)$ & 109.113 & $\mathrm{O}(37)-\mathrm{S}(35)-\mathrm{O}(34)$ & 107.794 & $\mathrm{O}(41)-\mathrm{V}(25)-\mathrm{O}(27)$ & 83.128 \\
\hline $\mathrm{H}(62)-\mathrm{O}(41)-\mathrm{C}(40)$ & 109.023 & $\mathrm{O}(36)-\mathrm{S}(35)-\mathrm{O}(34)$ & 109.261 & $\mathrm{O}(41)-\mathrm{V}(25)-\mathrm{O}(26)$ & 95.797 \\
\hline $\mathrm{O}(27)-\mathrm{V}(25)-\mathrm{N}(12)$ & 147.362 & $\mathrm{H}(62)-\mathrm{O}(41)-\mathrm{V}(25)$ & 107.179 & $\mathrm{~S}(35)-\mathrm{O}(34)-\mathrm{V}(32)$ & 130.421 \\
\hline $\mathrm{O}(26)-\mathrm{V}(25)-\mathrm{N}(19)$ & 166.165 & $\mathrm{C}(40)-\mathrm{O}(41)-\mathrm{V}(25)$ & 142.774 & $\mathrm{O}(44)-\mathrm{V}(32)-\mathrm{O}(34)$ & 95.231 \\
\hline $\mathrm{O}(26)-\mathrm{V}(25)-\mathrm{N}(12)$ & 94.015 & $\mathrm{H}(61)-\mathrm{C}(40)-\mathrm{H}(60)$ & 108.385 & $\mathrm{O}(44)-\mathrm{V}(32)-\mathrm{O}(33)$ & 86.794 \\
\hline $\mathrm{N}(19)-\mathrm{V}(25)-\mathrm{N}(12)$ & 72.546 & $\mathrm{H}(61)-\mathrm{C}(40)-\mathrm{O}(41)$ & 107.643 & $\mathrm{O}(44)-\mathrm{V}(32)-\mathrm{N}(8)$ & 99.02 \\
\hline $\mathrm{C}(23)-\mathrm{N}(24)-\mathrm{C}(13)$ & 121.115 & $\mathrm{O}(41)-\mathrm{V}(25)-\mathrm{N}(19)$ & 94.453 & $\mathrm{C}(21)-\mathrm{C}(20)-\mathrm{C}(13)$ & 119.502 \\
\hline $\mathrm{H}(56)-\mathrm{C}(23)-\mathrm{N}(24)$ & 116.45 & $\mathrm{O}(41)-\mathrm{V}(25)-\mathrm{N}(12)$ & 123.342 & V(25)-N(19)-C(18) & 125.354 \\
\hline H(56)-C(23)-C(22) & 121.296 & $\mathrm{O}(27)-\mathrm{V}(25)-\mathrm{O}(26)$ & 102.481 & V(25)-N(19)-C(14) & 109.524 \\
\hline N(24)-C(23)-C(22) & 122.251 & $\mathrm{O}(27)-\mathrm{V}(25)-\mathrm{N}(19)$ & 87.944 & C(18)-N(19)-C(14) & 118.644 \\
\hline $\mathrm{H}(55)-\mathrm{C}(22)-\mathrm{C}(23)$ & 120 & $\mathrm{H}(52)-\mathrm{C}(18)-\mathrm{N}(19)$ & 116.212 & $\mathrm{C}(11)-\mathrm{N}(12)-\mathrm{C}(7)$ & 116.157 \\
\hline $\mathrm{H}(55)-\mathrm{C}(22)-\mathrm{C}(21)$ & 121.929 & $\mathrm{H}(52)-\mathrm{C}(18)-\mathrm{C}(17)$ & 121.139 & $\mathrm{C}(14)-\mathrm{C}(11)-\mathrm{N}(12)$ & 118.3 \\
\hline $\mathrm{C}(23)-\mathrm{C}(22)-\mathrm{C}(21)$ & 118.07 & N(19)-C(18)-C(17) & 122.582 & $\mathrm{C}(14)-\mathrm{C}(11)-\mathrm{N}(10)$ & 119.474 \\
\hline $\mathrm{H}(54)-\mathrm{C}(21)-\mathrm{C}(22)$ & 120.543 & $\mathrm{H}(51)-\mathrm{C}(17)-\mathrm{C}(18)$ & 119.865 & $\mathrm{~N}(12)-\mathrm{C}(11)-\mathrm{N}(10)$ & 122.224 \\
\hline $\mathrm{H}(54)-\mathrm{C}(21)-\mathrm{C}(20)$ & 120.109 & $\mathrm{H}(51)-\mathrm{C}(17)-\mathrm{C}(16)$ & 120.804 & $\mathrm{C}(11)-\mathrm{N}(10)-\mathrm{C}(9)$ & 119.611 \\
\hline$C(22)-C(21)-C(20)$ & 119.346 & $\mathrm{C}(18)-\mathrm{C}(17)-\mathrm{C}(16)$ & 119.258 & $\mathrm{C}(13)-\mathrm{C}(9)-\mathrm{N}(10)$ & 117.717 \\
\hline $\mathrm{H}(53)-\mathrm{C}(20)-\mathrm{C}(21)$ & 120.683 & $\mathrm{H}(50)-\mathrm{C}(16)-\mathrm{C}(17)$ & 120.548 & $\mathrm{C}(13)-\mathrm{C}(9)-\mathrm{N}(8)$ & 120.657 \\
\hline H(53)-C(20)-C(13) & 119.811 & $\mathrm{H}(50)-\mathrm{C}(16)-\mathrm{C}(15)$ & 120.858 & $N(10)-C(9)-N(8)$ & 121.56 \\
\hline $\mathrm{H}(46)-\mathrm{C}(4)-\mathrm{C}(5)$ & 120.608 & $\mathrm{C}(17)-\mathrm{C}(16)-\mathrm{C}(15)$ & 118.59 & $\mathrm{~V}(32)-\mathrm{N}(8)-\mathrm{C}(9)$ & 135.179 \\
\hline $\mathrm{H}(46)-\mathrm{C}(4)-\mathrm{C}(3)$ & 119.363 & $\mathrm{H}(49)-\mathrm{C}(15)-\mathrm{C}(16)$ & 122.244 & $\mathrm{~V}(32)-\mathrm{N}(8)-\mathrm{C}(7)$ & 100.503 \\
\hline$C(5)-C(4)-C(3)$ & 120.019 & H(49)-C(15)-C(14) & 118.327 & $\mathrm{C}(9)-\mathrm{N}(8)-\mathrm{C}(7)$ & 116.009 \\
\hline $\mathrm{C}(7)-\mathrm{C}(3)-\mathrm{C}(4)$ & 124.396 & $\mathrm{C}(16)-\mathrm{C}(15)-\mathrm{C}(14)$ & 119.428 & $\mathrm{~N}(12)-\mathrm{C}(7)-\mathrm{N}(8)$ & 122.462 \\
\hline $\mathrm{C}(7)-\mathrm{C}(3)-\mathrm{N}(2)$ & 115.098 & $C(6)-C(5)-C(4)$ & 118.771 & $\mathrm{H}(47)-\mathrm{C}(5)-\mathrm{C}(4)$ & 119.911 \\
\hline $\mathrm{C}(4)-\mathrm{C}(3)-\mathrm{N}(2)$ & 120.486 & $\mathrm{C}(3)-\mathrm{N}(2)-\mathrm{C}(1)$ & 119.243 & N(19)-C(14)-C(15) & 121.467 \\
\hline $\mathrm{V}(32)-\mathrm{N}(2)-\mathrm{C}(3)$ & 109.155 & $\mathrm{H}(45)-\mathrm{C}(1)-\mathrm{C}(6)$ & 121.689 & $\mathrm{~N}(19)-\mathrm{C}(14)-\mathrm{C}(11)$ & 115.676 \\
\hline $\mathrm{V}(32)-\mathrm{N}(2)-\mathrm{C}(1)$ & 125.677 & $\mathrm{H}(45)-\mathrm{C}(1)-\mathrm{N}(2)$ & 115.816 & $\mathrm{C}(15)-\mathrm{C}(14)-\mathrm{C}(11)$ & 122.828 \\
\hline $\mathrm{C}(20)-\mathrm{C}(13)-\mathrm{C}(9)$ & 123.144 & $C(6)-C(1)-N(2)$ & 122.445 & N(24)-C(13)-C(20) & 119.708 \\
\hline $\mathrm{V}(25)-\mathrm{N}(12)-\mathrm{C}(11)$ & 106.841 & $\mathrm{H}(47)-\mathrm{C}(5)-\mathrm{C}(6)$ & 121.294 & $\mathrm{~N}(24)-\mathrm{C}(13)-\mathrm{C}(9)$ & 117.086 \\
\hline $\mathrm{V}(25)-\mathrm{N}(12)-\mathrm{C}(7)$ & 127.1 & $\mathrm{H}(48)-\mathrm{C}(6)-\mathrm{C}(5)$ & 121.764 & $\mathrm{~N}(8)-\mathrm{C}(7)-\mathrm{C}(3)$ & 116.828 \\
\hline $\mathrm{N}(12)-\mathrm{C}(7)-\mathrm{C}(3)$ & 120.709 & $\mathrm{H}(48)-\mathrm{C}(6)-\mathrm{C}(1)$ & 119.21 & $C(5)-C(6)-C(1)$ & 119.023 \\
\hline
\end{tabular}


Table S7. Bonds lengths $(\AA)$ of $\left[\mathrm{V}_{2} \mathrm{O}_{2}\left(\left(\mathrm{~L}^{1}\right)\right)\left(\mathrm{SO}_{4}\right)_{2}(\mathrm{EtOH})_{3 / 2}\left(\mathrm{H}_{2} \mathrm{O}\right)_{1 / 2}\right]$ using DFT-method from DMOL ${ }^{3}$ calculations.

\begin{tabular}{cccccccc}
\hline Bond & Length $(\AA)$ & Bond & Length $(\AA)$ & Bond & Length $(\AA)$ & Bond & Length $(\AA)$ \\
\hline $\mathrm{C}(43)-\mathrm{H}(62)$ & 1.102 & $\mathrm{~S}(28)-\mathrm{O}(29)$ & 2.067 & $\mathrm{C}(16)-\mathrm{C}(17)$ & 1.425 & $\mathrm{C}(5)-\mathrm{C}(6)$ & 1.427 \\
$\mathrm{C}(43)-\mathrm{H}(61)$ & 1.11 & $\mathrm{O}(27)-\mathrm{S}(28)$ & 3.046 & $\mathrm{~N}(15)-\mathrm{V}(34)$ & 2.167 & $\mathrm{~N}(4)-\mathrm{V}(25)$ & 2.209 \\
$\mathrm{C}(42)-\mathrm{H}(60)$ & 1.105 & $\mathrm{O}(32)-\mathrm{V}(25)$ & 2.264 & $\mathrm{~N}(15)-\mathrm{C}(16)$ & 1.386 & $\mathrm{~N}(4)-\mathrm{C}(5)$ & 1.391 \\
$\mathrm{C}(42)-\mathrm{H}(59)$ & 1.108 & $\mathrm{~V}(25)-\mathrm{O}(27)$ & 1.866 & $\mathrm{C}(24)-\mathrm{C}(14)$ & 1.438 & $\mathrm{C}(3)-\mathrm{C}(7)$ & 1.458 \\
$\mathrm{C}(42)-\mathrm{H}(58)$ & 1.11 & $\mathrm{~V}(25)-\mathrm{O}(26)$ & 1.831 & $\mathrm{C}(14)-\mathrm{N}(20)$ & 1.394 & $\mathrm{C}(3)-\mathrm{N}(4)$ & 1.41 \\
$\mathrm{C}(42)-\mathrm{C}(43)$ & 1.517 & $\mathrm{C}(24)-\mathrm{H}(55)$ & 1.094 & $\mathrm{C}(19)-\mathrm{C}(13)$ & 1.434 & $\mathrm{C}(2)-\mathrm{H}(45)$ & 1.095 \\
$\mathrm{O}(41)-\mathrm{H}(57)$ & 1.005 & $\mathrm{C}(23)-\mathrm{H}(54)$ & 1.095 & $\mathrm{C}(13)-\mathrm{N}(15)$ & 1.401 & $\mathrm{C}(2)-\mathrm{C}(3)$ & 1.434 \\
$\mathrm{O}(41)-\mathrm{H}(56)$ & 1.008 & $\mathrm{C}(23)-\mathrm{C}(24)$ & 1.426 & $\mathrm{~N}(12)-\mathrm{V}(25)$ & 2.215 & $\mathrm{C}(1)-\mathrm{H}(44)$ & 1.096 \\
$\mathrm{~S}(37)-\mathrm{O}(40)$ & 2.076 & $\mathrm{C}(22)-\mathrm{H}(53)$ & 1.097 & $\mathrm{C}(11)-\mathrm{C}(14)$ & 1.452 & $\mathrm{C}(6)-\mathrm{C}(1)$ & 1.428 \\
$\mathrm{~S}(37)-\mathrm{O}(39)$ & 2.099 & $\mathrm{C}(22)-\mathrm{C}(23)$ & 1.428 & $\mathrm{C}(11)-\mathrm{N}(12)$ & 1.406 & $\mathrm{C}(1)-\mathrm{C}(2)$ & 1.429 \\
$\mathrm{~S}(37)-\mathrm{O}(38)$ & 2.103 & $\mathrm{C}(21)-\mathrm{H}(52)$ & 1.091 & $\mathrm{~N}(10)-\mathrm{C}(11)$ & 1.389 & $\mathrm{~S}(28)-\mathrm{O}(30)$ & 2.137 \\
$\mathrm{O}(36)-\mathrm{S}(37)$ & 2.842 & $\mathrm{C}(21)-\mathrm{C}(22)$ & 1.428 & $\mathrm{C}(9)-\mathrm{C}(13)$ & 1.442 & $\mathrm{C}(16)-\mathrm{H}(48)$ & 1.091 \\
$\mathrm{O}(41)-\mathrm{V}(34)$ & 2.219 & $\mathrm{~N}(20)-\mathrm{C}(21)$ & 1.375 & $\mathrm{C}(9)-\mathrm{N}(10)$ & 1.379 & $\mathrm{C}(5)-\mathrm{H}(46)$ & 1.097 \\
$\mathrm{~V}(34)-\mathrm{O}(36)$ & 1.864 & $\mathrm{C}(19)-\mathrm{H}(51)$ & 1.096 & $\mathrm{~N}(8)-\mathrm{V}(34)$ & 2.221 & $\mathrm{~S}(28)-\mathrm{O}(31)$ & 2.076 \\
$\mathrm{~V}(34)-\mathrm{O}(35)$ & 1.896 & $\mathrm{C}(18)-\mathrm{H}(50)$ & 1.095 & $\mathrm{~N}(8)-\mathrm{C}(9)$ & 1.416 & $\mathrm{C}(17)-\mathrm{C}(18)$ & 1.432 \\
$\mathrm{O}(32)-\mathrm{C}(43)$ & 1.565 & $\mathrm{C}(18)-\mathrm{C}(19)$ & 1.423 & $\mathrm{~N}(12)-\mathrm{C}(7)$ & 1.423 & $\mathrm{C}(6)-\mathrm{H}(47)$ & 1.095 \\
$\mathrm{O}(32)-\mathrm{H}(33)$ & 1.008 & $\mathrm{C}(17)-\mathrm{H}(49)$ & 1.094 & $\mathrm{C}(7)-\mathrm{N}(8)$ & 1.409 & & \\
\hline
\end{tabular}

Table S8. Bonds angles $\left(^{\circ}\right)$ of $)\left[\mathrm{V}_{2} \mathrm{O}_{2}\left(\left(\mathbf{L}^{1}\right)\right)\left(\mathrm{SO}_{4}\right)_{2}(\mathrm{EtOH})_{3 / 2}\left(\mathrm{H}_{2} \mathrm{O}\right)_{1 / 2}\right]$ using DFT-method from $\mathrm{DMOL}^{3}$ calculations.

\begin{tabular}{cccccc}
\hline Angle & Degree $\left(^{\circ}\right)$ & Angle & Degree ( $\left.{ }^{\circ}\right)$ & Angle & Degree ( ${ }^{\circ}$ \\
\hline $\mathrm{H}(62)-\mathrm{C}(43)-\mathrm{H}(61)$ & 110.943 & $\mathrm{O}(38)-\mathrm{S}(37)-\mathrm{O}(36)$ & 91.951 & $\mathrm{O}(29)-\mathrm{S}(28)-\mathrm{O}(27)$ & 113.643 \\
$\mathrm{H}(62)-\mathrm{C}(43)-\mathrm{C}(42)$ & 113.191 & $\mathrm{~S}(37)-\mathrm{O}(36)-\mathrm{V}(34)$ & 128.184 & $\mathrm{~S}(28)-\mathrm{O}(27)-\mathrm{V}(25)$ & 107.182 \\
$\mathrm{H}(62)-\mathrm{C}(43)-\mathrm{O}(32)$ & 102.729 & $\mathrm{O}(41)-\mathrm{V}(34)-\mathrm{O}(36)$ & 93.833 & $\mathrm{O}(32)-\mathrm{V}(25)-\mathrm{O}(27)$ & 84.889 \\
$\mathrm{H}(61)-\mathrm{C}(43)-\mathrm{C}(42)$ & 113.709 & $\mathrm{O}(41)-\mathrm{V}(34)-\mathrm{O}(35)$ & 85.701 & $\mathrm{O}(32)-\mathrm{V}(25)-\mathrm{O}(26)$ & 177.473 \\
$\mathrm{H}(61)-\mathrm{C}(43)-\mathrm{O}(32)$ & 104.538 & $\mathrm{O}(41)-\mathrm{V}(34)-\mathrm{N}(15)$ & 173.796 & $\mathrm{O}(32)-\mathrm{V}(25)-\mathrm{N}(12)$ & 88.318 \\
$\mathrm{C}(42)-\mathrm{C}(43)-\mathrm{O}(32)$ & 110.822 & $\mathrm{O}(41)-\mathrm{V}(34)-\mathrm{N}(8)$ & 103.177 & $\mathrm{O}(32)-\mathrm{V}(25)-\mathrm{N}(4)$ & 84.507 \\
$\mathrm{H}(60)-\mathrm{C}(42)-\mathrm{H}(59)$ & 108.585 & $\mathrm{O}(36)-\mathrm{V}(34)-\mathrm{O}(35)$ & 131.659 & $\mathrm{O}(27)-\mathrm{V}(25)-\mathrm{O}(26)$ & 97.566 \\
$\mathrm{H}(60)-\mathrm{C}(42)-\mathrm{H}(58)$ & 107.962 & $\mathrm{O}(36)-\mathrm{V}(34)-\mathrm{N}(15)$ & 92.218 & $\mathrm{O}(27)-\mathrm{V}(25)-\mathrm{N}(12)$ & 141.1 \\
$\mathrm{H}(60)-\mathrm{C}(42)-\mathrm{C}(43)$ & 112.288 & $\mathrm{O}(36)-\mathrm{V}(34)-\mathrm{N}(8)$ & 108.783 & $\mathrm{O}(27)-\mathrm{V}(25)-\mathrm{N}(4)$ & 141.206 \\
$\mathrm{H}(59)-\mathrm{C}(42)-\mathrm{H}(58)$ & 108.532 & $\mathrm{O}(35)-\mathrm{V}(34)-\mathrm{N}(15)$ & 89.255 & $\mathrm{O}(26)-\mathrm{V}(25)-\mathrm{N}(12)$ & 90.125 \\
$\mathrm{H}(59)-\mathrm{C}(42)-\mathrm{C}(43)$ & 110.968 & $\mathrm{O}(35)-\mathrm{V}(34)-\mathrm{N}(8)$ & 118.377 & $\mathrm{O}(26)-\mathrm{V}(25)-\mathrm{N}(4)$ & 93.18 \\
$\mathrm{H}(58)-\mathrm{C}(42)-\mathrm{C}(43)$ & 108.396 & $\mathrm{~N}(15)-\mathrm{V}(34)-\mathrm{N}(8)$ & 76.09 & $\mathrm{~N}(12)-\mathrm{V}(25)-\mathrm{N}(4)$ & 75.621 \\
$\mathrm{H}(57)-\mathrm{O}(41)-\mathrm{H}(56)$ & 111.447 & $\mathrm{C}(43)-\mathrm{O}(32)-\mathrm{H}(33)$ & 109.95 & $\mathrm{H}(55)-\mathrm{C}(24)-\mathrm{C}(23)$ & 119.09 \\
$\mathrm{H}(57)-\mathrm{O}(41)-\mathrm{V}(34)$ & 123.793 & $\mathrm{C}(43)-\mathrm{O}(32)-\mathrm{V}(25)$ & 128.95 & $\mathrm{H}(55)-\mathrm{C}(24)-\mathrm{C}(14)$ & 120.911 \\
$\mathrm{H}(56)-\mathrm{O}(41)-\mathrm{V}(34)$ & 121.362 & $\mathrm{H}(33)-\mathrm{O}(32)-\mathrm{V}(25)$ & 106.043 & $\mathrm{C}(23)-\mathrm{C}(24)-\mathrm{C}(14)$ & 119.905 \\
$\mathrm{O}(40)-\mathrm{S}(37)-\mathrm{O}(39)$ & 119.199 & $\mathrm{O}(31)-\mathrm{S}(28)-\mathrm{O}(30)$ & 116.851 & $\mathrm{H}(54)-\mathrm{C}(23)-\mathrm{C}(24)$ & 119.514 \\
$\mathrm{O}(40)-\mathrm{S}(37)-\mathrm{O}(38)$ & 116.104 & $\mathrm{O}(31)-\mathrm{S}(28)-\mathrm{O}(29)$ & 120.482 & $\mathrm{H}(54)-\mathrm{C}(23)-\mathrm{C}(22)$ & 121.265 \\
$\mathrm{O}(40)-\mathrm{S}(37)-\mathrm{O}(36)$ & 88.774 & $\mathrm{O}(31)-\mathrm{S}(28)-\mathrm{O}(27)$ & 87.884 & $\mathrm{C}(24)-\mathrm{C}(23)-\mathrm{C}(22)$ & 119.22 \\
\hline
\end{tabular}




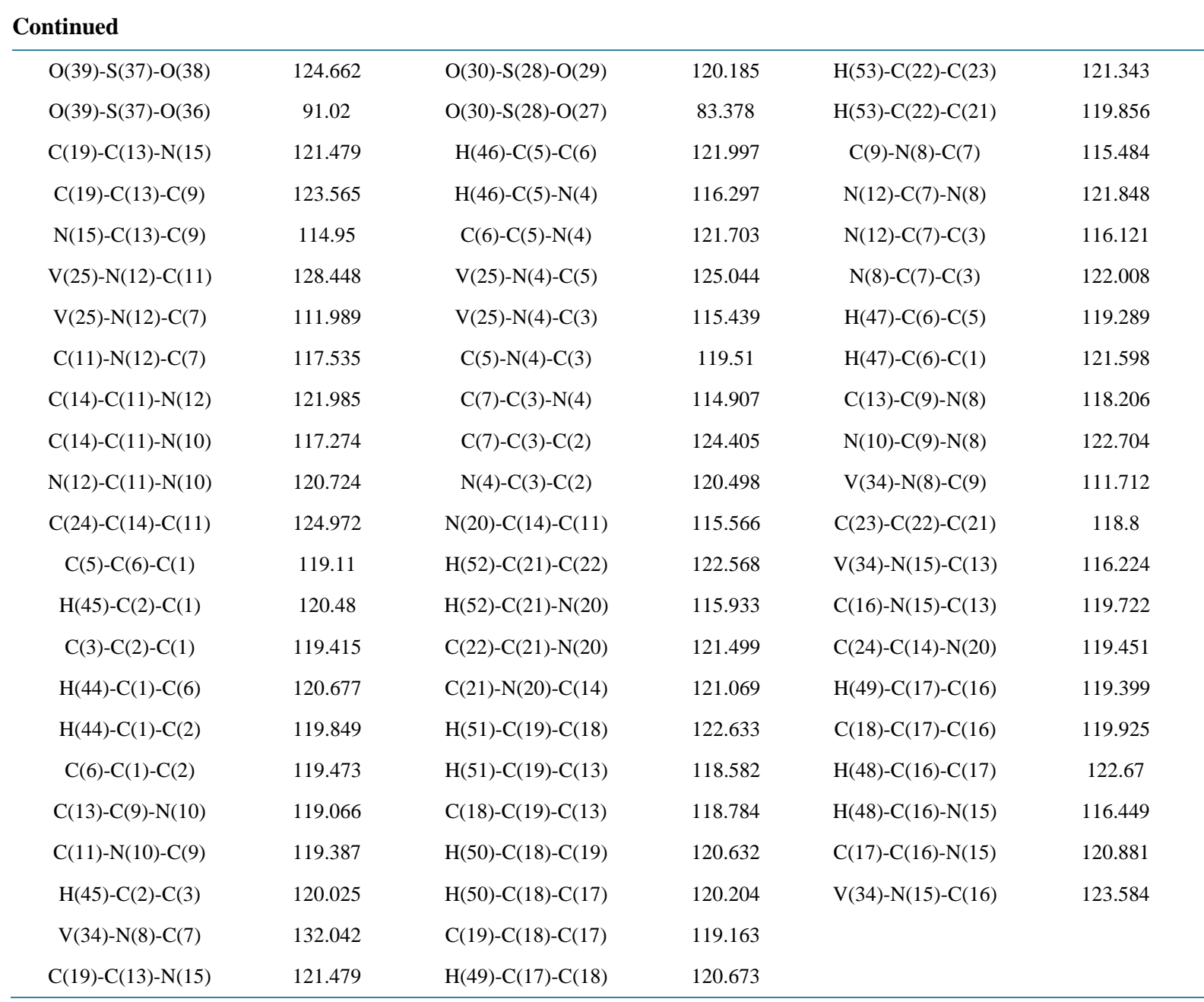

Table S9. Bonds lengths $(\AA)$ of $\left[\mathrm{VO}\left(\left(\mathrm{L}^{1}\right)\right) \mathrm{SO}_{4}\left(\mathrm{H}_{2} \mathrm{O}\right)_{3 / 2}\right] \cdot 2.5 \mathrm{H}_{2} \mathrm{O}$ using DFT-method from DMOL ${ }^{3}$ calculations.

\begin{tabular}{ccccccccc}
\hline Bond & Length $(\AA)$ & Bond & Length $(\AA)$ & Bond & Length $(\AA)$ & Bond & Length $(\AA)$ \\
\hline $\mathrm{O}(49)-\mathrm{H}(50)$ & 1.11 & $\mathrm{~N}(19)-\mathrm{V}(25)$ & 2.085 & $\mathrm{C}(8)-\mathrm{C}(15)$ & 1.535 & $\mathrm{C}(23)-\mathrm{C}(24)$ & 1.545 \\
$\mathrm{H}(48)-\mathrm{O}(49)$ & 1.11 & $\mathrm{C}(18)-\mathrm{H}(39)$ & 1.14 & $\mathrm{C}(24)-\mathrm{C}(7)$ & 1.535 & $\mathrm{C}(22)-\mathrm{H}(41)$ & 1.14 \\
$\mathrm{O}(46)-\mathrm{H}(47)$ & 1.11 & $\mathrm{C}(18)-\mathrm{N}(19)$ & 1.505 & $\mathrm{C}(7)-\mathrm{N}(20)$ & 1.531 & $\mathrm{C}(22)-\mathrm{C}(23)$ & 1.55 \\
$\mathrm{H}(45)-\mathrm{O}(46)$ & 1.11 & $\mathrm{C}(17)-\mathrm{H}(38)$ & 1.14 & $\mathrm{C}(6)-\mathrm{C}(7)$ & 1.571 & $\mathrm{C}(21)-\mathrm{H}(40)$ & 1.14 \\
$\mathrm{O}(31)-\mathrm{H}(44)$ & 0.942 & $\mathrm{C}(17)-\mathrm{C}(18)$ & 1.545 & $\mathrm{~N}(5)-\mathrm{V}(25)$ & 2.027 & $\mathrm{C}(21)-\mathrm{C}(22)$ & 1.545 \\
$\mathrm{~S}(28)-\mathrm{O}(31)$ & 1.78 & $\mathrm{C}(16)-\mathrm{H}(37)$ & 1.14 & $\mathrm{~N}(5)-\mathrm{C}(6)$ & 1.476 & $\mathrm{~N}(20)-\mathrm{V}(25)$ & 2.085 \\
$\mathrm{~S}(28)-\mathrm{O}(30)$ & 1.78 & $\mathrm{C}(16)-\mathrm{C}(17)$ & 1.55 & $\mathrm{C}(4)-\mathrm{C}(8)$ & 1.571 & $\mathrm{~N}(20)-\mathrm{C}(21)$ & 1.504 \\
$\mathrm{~S}(28)-\mathrm{O}(29)$ & 1.78 & $\mathrm{C}(15)-\mathrm{H}(36)$ & 1.14 & $\mathrm{C}(4)-\mathrm{N}(5)$ & 1.476 & $\mathrm{C}(12)-\mathrm{C}(13)$ & 1.538 \\
$\mathrm{O}(27)-\mathrm{S}(28)$ & 1.779 & $\mathrm{C}(15)-\mathrm{C}(16)$ & 1.545 & $\mathrm{~N}(3)-\mathrm{C}(4)$ & 1.509 & $\mathrm{C}(11)-\mathrm{H}(32)$ & 1.14 \\
$\mathrm{O}(27)-\mathrm{V}(25)$ & 2.091 & $\mathrm{C}(14)-\mathrm{H}(35)$ & 1.14 & $\mathrm{C}(2)-\mathrm{C}(9)$ & 1.54 & $\mathrm{C}(11)-\mathrm{C}(12)$ & 1.54 \\
$\mathrm{~V}(25)-\mathrm{O}(26)$ & 2.102 & $\mathrm{C}(13)-\mathrm{H}(34)$ & 1.14 & $\mathrm{C}(2)-\mathrm{N}(3)$ & 1.538 & $\mathrm{~N}(10)-\mathrm{C}(11)$ & 1.512 \\
$\mathrm{C}(24)-\mathrm{H}(43)$ & 1.14 & $\mathrm{C}(13)-\mathrm{C}(14)$ & 1.538 & $\mathrm{C}(6)-\mathrm{N}(1)$ & 1.509 & $\mathrm{C}(14)-\mathrm{C}(9)$ & 1.54 \\
$\mathrm{C}(23)-\mathrm{H}(42)$ & 1.14 & $\mathrm{C}(12)-\mathrm{H}(33)$ & 1.14 & $\mathrm{~N}(1)-\mathrm{C}(2)$ & 1.538 & $\mathrm{C}(9)-\mathrm{N}(10)$ & 1.511 \\
\hline
\end{tabular}




\begin{tabular}{cccccccc} 
Continued & \multicolumn{7}{l}{ 积 } \\
\hline $\mathrm{N}(19)-\mathrm{C}(8)$ & 1.531 & $\mathrm{O}(49)-\mathrm{H}(50)$ & 1.11 & $\mathrm{C}(16)-\mathrm{H}(37)$ & 1.14 & $\mathrm{C}(2)-\mathrm{N}(3)$ & 1.538 \\
$\mathrm{H}(48)-\mathrm{O}(49)$ & 1.11 & $\mathrm{C}(16)-\mathrm{C}(17)$ & 1.55 & $\mathrm{C}(6)-\mathrm{N}(1)$ & 1.509 & $\mathrm{~N}(19)-\mathrm{C}(8)$ & 1.531 \\
$\mathrm{O}(46)-\mathrm{H}(47)$ & 1.11 & $\mathrm{C}(15)-\mathrm{H}(36)$ & 1.14 & $\mathrm{~N}(1)-\mathrm{C}(2)$ & 1.538 & $\mathrm{C}(8)-\mathrm{C}(15)$ & 1.535 \\
$\mathrm{H}(45)-\mathrm{O}(46)$ & 1.11 & $\mathrm{C}(15)-\mathrm{C}(16)$ & 1.545 & $\mathrm{C}(22)-\mathrm{H}(41)$ & 1.14 & $\mathrm{C}(24)-\mathrm{C}(7)$ & 1.535 \\
$\mathrm{O}(31)-\mathrm{H}(44)$ & 0.942 & $\mathrm{C}(14)-\mathrm{H}(35)$ & 1.14 & $\mathrm{C}(22)-\mathrm{C}(23)$ & 1.55 & $\mathrm{C}(7)-\mathrm{N}(20)$ & 1.531 \\
$\mathrm{~S}(28)-\mathrm{O}(31)$ & 1.78 & $\mathrm{C}(13)-\mathrm{H}(34)$ & 1.14 & $\mathrm{C}(21)-\mathrm{H}(40)$ & 1.14 & $\mathrm{C}(6)-\mathrm{C}(7)$ & 1.571 \\
$\mathrm{~S}(28)-\mathrm{O}(30)$ & 1.78 & $\mathrm{C}(13)-\mathrm{C}(14)$ & 1.538 & $\mathrm{C}(21)-\mathrm{C}(22)$ & 1.545 & $\mathrm{~N}(5)-\mathrm{V}(25)$ & 2.027 \\
$\mathrm{~S}(28)-\mathrm{O}(29)$ & 1.78 & $\mathrm{C}(12)-\mathrm{H}(33)$ & 1.14 & $\mathrm{~N}(20)-\mathrm{V}(25)$ & 2.085 & $\mathrm{~N}(5)-\mathrm{C}(6)$ & 1.476 \\
$\mathrm{O}(27)-\mathrm{S}(28)$ & 1.779 & $\mathrm{C}(12)-\mathrm{C}(13)$ & 1.538 & $\mathrm{~N}(20)-\mathrm{C}(21)$ & 1.504 & $\mathrm{C}(4)-\mathrm{C}(8)$ & 1.571 \\
$\mathrm{O}(27)-\mathrm{V}(25)$ & 2.091 & $\mathrm{C}(11)-\mathrm{H}(32)$ & 1.14 & $\mathrm{~N}(19)-\mathrm{V}(25)$ & 2.085 & $\mathrm{C}(4)-\mathrm{N}(5)$ & 1.476 \\
$\mathrm{~V}(25)-\mathrm{O}(26)$ & 2.102 & $\mathrm{C}(11)-\mathrm{C}(12)$ & 1.54 & $\mathrm{C}(18)-\mathrm{H}(39)$ & 1.14 & $\mathrm{~N}(3)-\mathrm{C}(4)$ & 1.509 \\
$\mathrm{C}(24)-\mathrm{H}(43)$ & 1.14 & $\mathrm{~N}(10)-\mathrm{C}(11)$ & 1.512 & $\mathrm{C}(18)-\mathrm{N}(19)$ & 1.505 & $\mathrm{C}(2)-\mathrm{C}(9)$ & 1.54 \\
$\mathrm{C}(23)-\mathrm{H}(42)$ & 1.14 & $\mathrm{C}(14)-\mathrm{C}(9)$ & 1.54 & $\mathrm{C}(17)-\mathrm{H}(38)$ & 1.14 & & \\
$\mathrm{C}(23)-\mathrm{C}(24)$ & 1.545 & $\mathrm{C}(9)-\mathrm{N}(10)$ & 1.511 & $\mathrm{C}(17)-\mathrm{C}(18)$ & 1.545 & & \\
\hline
\end{tabular}

Table S10. Bonds angles $\left(^{\circ}\right)$ of $\left[\mathrm{VO}\left(\left(\mathbf{L}^{1}\right)\right) \mathrm{SO}_{4}\left(\mathrm{H}_{2} \mathrm{O}\right)_{3 / 2}\right] \cdot 2.5 \mathrm{H}_{2} \mathrm{O}$ using DFT-method from $\mathrm{DMOL}^{3}$ calculations.

\begin{tabular}{|c|c|c|c|c|c|}
\hline Angle & Degree ( $\left.{ }^{\circ}\right)$ & Angle & Degree $\left({ }^{\circ}\right)$ & Angle & Degree $\left({ }^{\circ}\right)$ \\
\hline $\mathrm{H}(50)-\mathrm{O}(49)-\mathrm{H}(48)$ & 109.279 & $\mathrm{C}(23)-\mathrm{C}(24)-\mathrm{C}(7)$ & 118.499 & $\mathrm{H}(36)-\mathrm{C}(15)-\mathrm{C}(16)$ & 120.772 \\
\hline $\mathrm{H}(47)-\mathrm{O}(46)-\mathrm{H}(45)$ & 109.385 & $\mathrm{H}(42)-\mathrm{C}(23)-\mathrm{C}(24)$ & 119.888 & H(36)-C(15)-C(8) & 120.725 \\
\hline $\mathrm{H}(44)-\mathrm{O}(31)-\mathrm{S}(28)$ & 120.005 & $\mathrm{H}(42)-\mathrm{C}(23)-\mathrm{C}(22)$ & 119.894 & $C(16)-C(15)-C(8)$ & 118.499 \\
\hline $\mathrm{O}(31)-\mathrm{S}(28)-\mathrm{O}(30)$ & 109.438 & $C(24)-C(23)-C(22)$ & 120.215 & $\mathrm{H}(35)-\mathrm{C}(14)-\mathrm{C}(13)$ & 120.163 \\
\hline $\mathrm{O}(31)-\mathrm{S}(28)-\mathrm{O}(29)$ & 109.23 & $\mathrm{H}(41)-\mathrm{C}(22)-\mathrm{C}(23)$ & 119.861 & H(35)-C(14)-C(9) & 120.125 \\
\hline $\mathrm{O}(31)-\mathrm{S}(28)-\mathrm{O}(27)$ & 108.74 & $\mathrm{H}(41)-\mathrm{C}(22)-\mathrm{C}(21)$ & 119.859 & $\mathrm{C}(13)-\mathrm{C}(14)-\mathrm{C}(9)$ & 119.708 \\
\hline $\mathrm{O}(30)-\mathrm{S}(28)-\mathrm{O}(29)$ & 110.311 & $C(23)-C(22)-C(21)$ & 120.279 & $\mathrm{H}(34)-\mathrm{C}(13)-\mathrm{C}(14)$ & 120.266 \\
\hline $\mathrm{O}(30)-\mathrm{S}(28)-\mathrm{O}(27)$ & 109.634 & $\mathrm{H}(40)-\mathrm{C}(21)-\mathrm{C}(22)$ & 120.814 & $\mathrm{H}(34)-\mathrm{C}(13)-\mathrm{C}(12)$ & 120.254 \\
\hline $\mathrm{O}(29)-\mathrm{S}(28)-\mathrm{O}(27)$ & 109.462 & $\mathrm{H}(40)-\mathrm{C}(21)-\mathrm{N}(20)$ & 120.706 & $\mathrm{C}(14)-\mathrm{C}(13)-\mathrm{C}(12)$ & 119.48 \\
\hline $\mathrm{S}(28)-\mathrm{O}(27)-\mathrm{V}(25)$ & 112.522 & $\mathrm{C}(22)-\mathrm{C}(21)-\mathrm{N}(20)$ & 118.481 & $\mathrm{H}(33)-\mathrm{C}(12)-\mathrm{C}(13)$ & 120.144 \\
\hline $\mathrm{O}(27)-\mathrm{V}(25)-\mathrm{O}(26)$ & 93.018 & $\mathrm{~V}(25)-\mathrm{N}(20)-\mathrm{C}(21)$ & 126.77 & $\mathrm{H}(33)-\mathrm{C}(12)-\mathrm{C}(11)$ & 120.143 \\
\hline $\mathrm{O}(27)-\mathrm{V}(25)-\mathrm{N}(20)$ & 94.073 & V(25)-N(20)-C(7) & 110.775 & $\mathrm{C}(13)-\mathrm{C}(12)-\mathrm{C}(11)$ & 119.713 \\
\hline $\mathrm{O}(27)-\mathrm{V}(25)-\mathrm{N}(19)$ & 94.125 & $\mathrm{C}(21)-\mathrm{N}(20)-\mathrm{C}(7)$ & 122.125 & $\mathrm{H}(32)-\mathrm{C}(11)-\mathrm{C}(12)$ & 119.896 \\
\hline $\mathrm{O}(27)-\mathrm{V}(25)-\mathrm{N}(5)$ & 173.294 & V(25)-N(19)-C(18) & 126.794 & $\mathrm{H}(32)-\mathrm{C}(11)-\mathrm{N}(10)$ & 119.905 \\
\hline $\mathrm{O}(26)-\mathrm{V}(25)-\mathrm{N}(20)$ & 93.283 & V(25)-N(19)-C(8) & 110.794 & $\mathrm{C}(12)-\mathrm{C}(11)-\mathrm{N}(10)$ & 120.198 \\
\hline $\mathrm{O}(26)-\mathrm{V}(25)-\mathrm{N}(19)$ & 93.235 & C(18)-N(19)-C(8) & 122.105 & $\mathrm{C}(11)-\mathrm{N}(10)-\mathrm{C}(9)$ & 120.686 \\
\hline $\mathrm{O}(26)-\mathrm{V}(25)-\mathrm{N}(5)$ & 93.688 & $\mathrm{H}(39)-\mathrm{C}(18)-\mathrm{N}(19)$ & 120.726 & $\mathrm{C}(14)-\mathrm{C}(9)-\mathrm{N}(10)$ & 120.207 \\
\hline $\mathrm{N}(20)-\mathrm{V}(25)-\mathrm{N}(19)$ & 169.239 & $\mathrm{H}(39)-\mathrm{C}(18)-\mathrm{C}(17)$ & 120.763 & $\mathrm{C}(14)-\mathrm{C}(9)-\mathrm{C}(2)$ & 119.883 \\
\hline N(20)-V(25)-N(5) & 85.538 & $\mathrm{~N}(19)-\mathrm{C}(18)-\mathrm{C}(17)$ & 118.51 & N(10)-C(9)-C(2) & 119.877 \\
\hline $\mathrm{N}(19)-\mathrm{V}(25)-\mathrm{N}(5)$ & 85.506 & $\mathrm{H}(38)-\mathrm{C}(17)-\mathrm{C}(18)$ & 119.889 & $\mathrm{~N}(19)-\mathrm{C}(8)-\mathrm{C}(15)$ & 120.22 \\
\hline $\mathrm{H}(43)-\mathrm{C}(24)-\mathrm{C}(23)$ & 120.754 & $\mathrm{H}(38)-\mathrm{C}(17)-\mathrm{C}(16)$ & 119.874 & N(19)-C(8)-C(4) & 114.869 \\
\hline $\mathrm{H}(43)-\mathrm{C}(24)-\mathrm{C}(7)$ & 120.745 & $\mathrm{C}(18)-\mathrm{C}(17)-\mathrm{C}(16)$ & 120.237 & $\mathrm{C}(15)-\mathrm{C}(8)-\mathrm{C}(4)$ & 124.909 \\
\hline $\mathrm{C}(7)-\mathrm{C}(6)-\mathrm{N}(5)$ & 112.978 & $H(37)-C(16)-C(17)$ & 119.882 & $\mathrm{C}(24)-\mathrm{C}(7)-\mathrm{N}(20)$ & 120.216 \\
\hline $\mathrm{C}(7)-\mathrm{C}(6)-\mathrm{N}(1)$ & 129.039 & $\mathrm{H}(37)-\mathrm{C}(16)-\mathrm{C}(15)$ & 119.861 & $\mathrm{C}(24)-\mathrm{C}(7)-\mathrm{C}(6)$ & 124.922 \\
\hline $\mathrm{N}(5)-\mathrm{C}(6)-\mathrm{N}(1)$ & 117.551 & $\mathrm{C}(17)-\mathrm{C}(16)-\mathrm{C}(15)$ & 120.256 & $N(20)-C(7)-C(6)$ & 114.861 \\
\hline $\mathrm{C}(7)-\mathrm{C}(6)-\mathrm{N}(5)$ & 112.978 & V(25)-N(5)-C(4) & 115.616 & $\mathrm{~N}(5)-\mathrm{C}(4)-\mathrm{N}(3)$ & 117.515 \\
\hline $\mathrm{C}(7)-\mathrm{C}(6)-\mathrm{N}(1)$ & 129.039 & $\mathrm{C}(6)-\mathrm{N}(5)-\mathrm{C}(4)$ & 126.748 & $\mathrm{C}(4)-\mathrm{N}(3)-\mathrm{C}(2)$ & 118.028 \\
\hline $\mathrm{N}(5)-\mathrm{C}(6)-\mathrm{N}(1)$ & 117.551 & $\mathrm{C}(8)-\mathrm{C}(4)-\mathrm{N}(5)$ & 112.953 & $\mathrm{C}(9)-\mathrm{C}(2)-\mathrm{N}(3)$ & 118.926 \\
\hline V(25)-N(5)-C(6) & 115.562 & $\mathrm{C}(8)-\mathrm{C}(4)-\mathrm{N}(3)$ & 129.08 & $\mathrm{C}(9)-\mathrm{C}(2)-\mathrm{N}(1)$ & 119.063 \\
\hline $\mathrm{N}(3)-\mathrm{C}(2)-\mathrm{N}(1)$ & 121.933 & $\mathrm{C}(6)-\mathrm{N}(1)-\mathrm{C}(2)$ & 118 & & \\
\hline
\end{tabular}


Table S11. Bonds lengths $(\AA)$ of $\left[\mathrm{V}_{2} \mathrm{O}_{2}\left(\left(\mathbf{L}^{1}\right)\right)\left(\mathrm{SO}_{4}\right)_{2}\left(\mathrm{H}_{2} \mathrm{O}\right)\right] \cdot \mathrm{H}_{2} \mathrm{O}$ using DFT-method from DMOL ${ }^{3}$ calculations.

\begin{tabular}{|c|c|c|c|c|c|c|c|}
\hline Bond & Length ( $(\AA)$ & Bond & Length (Å) & Bond & Length ( $(\AA)$ & Bond & Length ( $(\AA)$ \\
\hline $\mathrm{O}(39)-\mathrm{H}(55)$ & 0.942 & $C(22)-C(23)$ & 1.497 & $N(10)-V(25)$ & 2.093 & $\mathrm{O}(39)-\mathrm{H}(55)$ & 0.942 \\
\hline $\mathrm{O}(30)-\mathrm{H}(54)$ & 0.942 & $\mathrm{C}(21)-\mathrm{H}(48)$ & 1.121 & $\mathrm{~N}(10)-\mathrm{C}(11)$ & 1.463 & $\mathrm{O}(30)-\mathrm{H}(54)$ & 0.942 \\
\hline $\mathrm{S}(36)-\mathrm{O}(39)$ & 1.761 & $C(21)-C(22)$ & 1.494 & $C(24)-C(9)$ & 1.492 & $\mathrm{~S}(36)-\mathrm{O}(39)$ & 1.761 \\
\hline $\mathrm{S}(36)-\mathrm{O}(38)$ & 1.757 & $N(20)-V(32)$ & 2.091 & $\mathrm{C}(9)-\mathrm{N}(20)$ & 1.466 & $\mathrm{~S}(36)-\mathrm{O}(38)$ & 1.757 \\
\hline $\mathrm{S}(36)-\mathrm{O}(37)$ & 1.763 & $N(20)-C(21)$ & 1.467 & $\mathrm{~N}(19)-\mathrm{C}(8)$ & 1.476 & $\mathrm{~S}(36)-\mathrm{O}(37)$ & 1.763 \\
\hline $\mathrm{O}(35)-\mathrm{S}(36)$ & 1.784 & $N(19)-V(25)$ & 2.106 & $\mathrm{C}(8)-\mathrm{C}(15)$ & 1.491 & $\mathrm{O}(35)-\mathrm{S}(36)$ & 1.784 \\
\hline $\mathrm{O}(34)-\mathrm{H}(53)$ & 1.075 & $\mathrm{C}(18)-\mathrm{H}(47)$ & 1.123 & $\mathrm{C}(14)-\mathrm{C}(7)$ & 1.498 & $\mathrm{O}(34)-\mathrm{H}(53)$ & 1.075 \\
\hline $\mathrm{O}(34)-\mathrm{H}(52)$ & 1.077 & $\mathrm{C}(18)-\mathrm{N}(19)$ & 1.464 & $\mathrm{C}(7)-\mathrm{N}(10)$ & 1.482 & $\mathrm{O}(34)-\mathrm{H}(52)$ & 1.077 \\
\hline $\mathrm{V}(32)-\mathrm{O}(35)$ & 2.073 & $\mathrm{C}(17)-\mathrm{H}(46)$ & 1.124 & $\mathrm{C}(6)-\mathrm{C}(7)$ & 1.517 & $\mathrm{~V}(32)-\mathrm{O}(35)$ & 2.073 \\
\hline $\mathrm{O}(34)-\mathrm{V}(32)$ & 2.1 & $\mathrm{C}(17)-\mathrm{C}(18)$ & 1.496 & $N(5)-V(25)$ & 2.064 & $\mathrm{O}(34)-\mathrm{V}(32)$ & 2.1 \\
\hline $\mathrm{V}(32)-\mathrm{O}(33)$ & 1.999 & $\mathrm{C}(16)-\mathrm{H}(45)$ & 1.124 & $\mathrm{~N}(5)-\mathrm{C}(6)$ & 1.454 & $\mathrm{~V}(32)-\mathrm{O}(33)$ & 1.999 \\
\hline $\mathrm{S}(27)-\mathrm{O}(30)$ & 1.758 & $\mathrm{C}(16)-\mathrm{C}(17)$ & 1.497 & $\mathrm{C}(4)-\mathrm{C}(8)$ & 1.502 & $\mathrm{~S}(27)-\mathrm{O}(30)$ & 1.758 \\
\hline $\mathrm{S}(27)-\mathrm{O}(29)$ & 1.762 & $\mathrm{C}(15)-\mathrm{H}(44)$ & 1.123 & $\mathrm{C}(4)-\mathrm{N}(5)$ & 1.455 & $\mathrm{~S}(27)-\mathrm{O}(29)$ & 1.762 \\
\hline $\mathrm{S}(27)-\mathrm{O}(28)$ & 1.763 & $\mathrm{C}(15)-\mathrm{C}(16)$ & 1.491 & N(3)-C(4) & 1.461 & $\mathrm{~S}(27)-\mathrm{O}(28)$ & 1.763 \\
\hline $\mathrm{O}(26)-\mathrm{S}(27)$ & 1.79 & $\mathrm{C}(14)-\mathrm{H}(43)$ & 1.119 & $\mathrm{C}(2)-\mathrm{C}(9)$ & 1.497 & $\mathrm{O}(26)-\mathrm{S}(27)$ & 1.79 \\
\hline $\mathrm{V}(25)-\mathrm{O}(31)$ & 1.99 & $\mathrm{C}(13)-\mathrm{H}(42)$ & 1.124 & $\mathrm{C}(2)-\mathrm{N}(3)$ & 1.475 & $\mathrm{~V}(25)-\mathrm{O}(31)$ & 1.99 \\
\hline $\mathrm{V}(25)-\mathrm{O}(26)$ & 2.073 & $\mathrm{C}(13)-\mathrm{C}(14)$ & 1.493 & $\mathrm{~N}(1)-\mathrm{V}(32)$ & 2.104 & $\mathrm{~V}(25)-\mathrm{O}(26)$ & 2.073 \\
\hline $\mathrm{C}(24)-\mathrm{H}(51)$ & 1.123 & $\mathrm{C}(12)-\mathrm{H}(41)$ & 1.123 & $\mathrm{C}(6)-\mathrm{N}(1)$ & 1.478 & $\mathrm{C}(24)-\mathrm{H}(51)$ & 1.123 \\
\hline $\mathrm{C}(23)-\mathrm{H}(50)$ & 1.124 & $\mathrm{C}(12)-\mathrm{C}(13)$ & 1.495 & $\mathrm{~N}(1)-\mathrm{C}(2)$ & 1.489 & $\mathrm{C}(23)-\mathrm{H}(50)$ & 1.124 \\
\hline$C(23)-C(24)$ & 1.491 & $\mathrm{C}(11)-\mathrm{H}(40)$ & 1.124 & $\mathrm{C}(15)-\mathrm{H}(44)$ & 1.123 & $C(23)-C(24)$ & 1.491 \\
\hline $\mathrm{C}(22)-\mathrm{H}(49)$ & 1.124 & $\mathrm{C}(11)-\mathrm{C}(12)$ & 1.493 & $\mathrm{~N}(19)-\mathrm{V}(25)$ & 2.106 & N(19)-C(8) & 1.476 \\
\hline $\mathrm{C}(22)-\mathrm{H}(49)$ & 1.124 & $\mathrm{C}(11)-\mathrm{H}(40)$ & 1.124 & $\mathrm{C}(18)-\mathrm{H}(47)$ & 1.123 & $\mathrm{C}(8)-\mathrm{C}(15)$ & 1.491 \\
\hline$C(22)-C(23)$ & 1.497 & $\mathrm{C}(11)-\mathrm{C}(12)$ & 1.493 & $\mathrm{C}(18)-\mathrm{N}(19)$ & 1.464 & $\mathrm{C}(14)-\mathrm{C}(7)$ & 1.498 \\
\hline $\mathrm{C}(21)-\mathrm{H}(48)$ & 1.121 & $N(10)-V(25)$ & 2.093 & $\mathrm{C}(17)-\mathrm{H}(46)$ & 1.124 & $\mathrm{C}(7)-\mathrm{N}(10)$ & 1.482 \\
\hline$C(21)-C(22)$ & 1.494 & $N(10)-C(11)$ & 1.463 & $\mathrm{C}(17)-\mathrm{C}(18)$ & 1.496 & $\mathrm{C}(6)-\mathrm{C}(7)$ & 1.517 \\
\hline$N(20)-V(32)$ & 2.091 & $C(24)-C(9)$ & 1.492 & $\mathrm{C}(16)-\mathrm{H}(45)$ & 1.124 & $\mathrm{~N}(5)-\mathrm{V}(25)$ & 2.064 \\
\hline $\mathrm{N}(20)-\mathrm{C}(21)$ & 1.467 & $\mathrm{C}(9)-\mathrm{N}(20)$ & 1.466 & $\mathrm{C}(16)-\mathrm{C}(17)$ & 1.497 & $\mathrm{~N}(5)-\mathrm{C}(6)$ & 1.454 \\
\hline$C(4)-C(8)$ & 1.502 & $\mathrm{~N}(1)-\mathrm{C}(2)$ & 1.489 & $\mathrm{C}(13)-\mathrm{C}(14)$ & 1.493 & $\mathrm{C}(2)-\mathrm{N}(3)$ & 1.475 \\
\hline $\mathrm{C}(15)-\mathrm{C}(16)$ & 1.491 & $C(4)-N(5)$ & 1.455 & $\mathrm{C}(12)-\mathrm{H}(41)$ & 1.123 & $\mathrm{~N}(1)-\mathrm{V}(32)$ & 2.104 \\
\hline $\mathrm{C}(14)-\mathrm{H}(43)$ & 1.119 & $\mathrm{~N}(3)-\mathrm{C}(4)$ & 1.461 & $\mathrm{C}(12)-\mathrm{C}(13)$ & 1.495 & $\mathrm{C}(6)-\mathrm{N}(1)$ & 1.478 \\
\hline $\mathrm{C}(13)-\mathrm{H}(42)$ & 1.124 & $\mathrm{C}(2)-\mathrm{C}(9)$ & 1.497 & & & & \\
\hline
\end{tabular}

Table S12. Bonds angles $\left(^{\circ}\right)$ of $\left[\mathrm{V}_{2} \mathrm{O}_{2}\left(\left(\mathbf{L}^{1}\right)\right)\left(\mathrm{SO}_{4}\right)_{2}\left(\mathrm{H}_{2} \mathrm{O}\right)\right] \cdot \mathrm{H}_{2} \mathrm{O}$ using DFT-method from DMOL ${ }^{3}$ calculations.

\begin{tabular}{cccccc}
\hline Angle & Degree $\left(^{\circ}\right)$ & Angle & Degree $\left(^{\circ}\right)$ & Angle & Degree $\left(^{\circ}\right)$ \\
\hline $\mathrm{H}(55)-\mathrm{O}(39)-\mathrm{S}(36)$ & 120 & $\mathrm{O}(33)-\mathrm{V}(32)-\mathrm{N}(1)$ & 90.746 & $\mathrm{H}(51)-\mathrm{C}(24)-\mathrm{C}(23)$ & 120.978 \\
$\mathrm{O}(39)-\mathrm{S}(36)-\mathrm{O}(38)$ & 110.528 & $\mathrm{~N}(20)-\mathrm{V}(32)-\mathrm{N}(1)$ & 80.514 & $\mathrm{H}(51)-\mathrm{C}(24)-\mathrm{C}(9)$ & 120.439 \\
$\mathrm{O}(39)-\mathrm{S}(36)-\mathrm{O}(37)$ & 110.11 & $\mathrm{H}(54)-\mathrm{O}(30)-\mathrm{S}(27)$ & 120 & $\mathrm{C}(23)-\mathrm{C}(24)-\mathrm{C}(9)$ & 118.583 \\
$\mathrm{O}(39)-\mathrm{S}(36)-\mathrm{O}(35)$ & 108.727 & $\mathrm{O}(30)-\mathrm{S}(27)-\mathrm{O}(29)$ & 109.937 & $\mathrm{H}(50)-\mathrm{C}(23)-\mathrm{C}(24)$ & 120.141 \\
$\mathrm{O}(38)-\mathrm{S}(36)-\mathrm{O}(37)$ & 109.694 & $\mathrm{O}(30)-\mathrm{S}(27)-\mathrm{O}(28)$ & 109.917 & $\mathrm{H}(50)-\mathrm{C}(23)-\mathrm{C}(22)$ & 120.278 \\
\hline
\end{tabular}




\section{Continued}

\begin{tabular}{|c|c|c|c|c|c|}
\hline $\mathrm{O}(38)-\mathrm{S}(36)-\mathrm{O}(35)$ & 108.451 & $\mathrm{O}(30)-\mathrm{S}(27)-\mathrm{O}(26)$ & 108.458 & $C(24)-C(23)-C(22)$ & 119.581 \\
\hline $\mathrm{O}(37)-\mathrm{S}(36)-\mathrm{O}(35)$ & 109.293 & $\mathrm{O}(29)-\mathrm{S}(27)-\mathrm{O}(28)$ & 110.646 & H(49)-C(22)-C(23) & 120.242 \\
\hline $\mathrm{S}(36)-\mathrm{O}(35)-\mathrm{V}(32)$ & 112.568 & $\mathrm{O}(29)-\mathrm{S}(27)-\mathrm{O}(26)$ & 109.504 & $\mathrm{H}(49)-\mathrm{C}(22)-\mathrm{C}(21)$ & 119.742 \\
\hline $\mathrm{H}(53)-\mathrm{O}(34)-\mathrm{H}(52)$ & 108.492 & $\mathrm{O}(28)-\mathrm{S}(27)-\mathrm{O}(26)$ & 108.331 & $C(23)-C(22)-C(21)$ & 120.016 \\
\hline $\mathrm{H}(53)-\mathrm{O}(34)-\mathrm{V}(32)$ & 110.595 & $\mathrm{~S}(27)-\mathrm{O}(26)-\mathrm{V}(25)$ & 114.737 & $\mathrm{H}(48)-\mathrm{C}(21)-\mathrm{C}(22)$ & 120.645 \\
\hline $\mathrm{H}(52)-\mathrm{O}(34)-\mathrm{V}(32)$ & 110.491 & $\mathrm{O}(31)-\mathrm{V}(25)-\mathrm{O}(26)$ & 103.976 & $\mathrm{H}(48)-\mathrm{C}(21)-\mathrm{N}(20)$ & 119.11 \\
\hline $\mathrm{O}(35)-\mathrm{V}(32)-\mathrm{O}(34)$ & 94.37 & $\mathrm{O}(31)-\mathrm{V}(25)-\mathrm{N}(19)$ & 101.385 & $\mathrm{C}(22)-\mathrm{C}(21)-\mathrm{N}(20)$ & 120.245 \\
\hline $\mathrm{O}(35)-\mathrm{V}(32)-\mathrm{O}(33)$ & 91.243 & $\mathrm{O}(31)-\mathrm{V}(25)-\mathrm{N}(10)$ & 100.722 & V(32)-N(20)-C(21) & 124.284 \\
\hline $\mathrm{O}(35)-\mathrm{V}(32)-\mathrm{N}(20)$ & 89.681 & $\mathrm{O}(31)-\mathrm{V}(25)-\mathrm{N}(5)$ & 113.062 & V(32)-N(20)-C(9) & 116.11 \\
\hline $\mathrm{O}(35)-\mathrm{V}(32)-\mathrm{N}(1)$ & 168.352 & $\mathrm{O}(26)-\mathrm{V}(25)-\mathrm{N}(19)$ & 94.461 & $\mathrm{C}(21)-\mathrm{N}(20)-\mathrm{C}(9)$ & 119.594 \\
\hline $\mathrm{O}(34)-\mathrm{V}(32)-\mathrm{O}(33)$ & 111.648 & $\mathrm{O}(26)-\mathrm{V}(25)-\mathrm{N}(10)$ & 94.646 & V(25)-N(19)-C(18) & 124.659 \\
\hline $\mathrm{O}(34)-\mathrm{V}(32)-\mathrm{N}(20)$ & 115.849 & $\mathrm{O}(26)-\mathrm{V}(25)-\mathrm{N}(5)$ & 142.96 & V(25)-N(19)-C(8) & 115.79 \\
\hline $\mathrm{O}(34)-\mathrm{V}(32)-\mathrm{N}(1)$ & 95.557 & N(19)-V(25)-N(10) & 153.243 & $\mathrm{C}(18)-\mathrm{N}(19)-\mathrm{C}(8)$ & 119.282 \\
\hline $\mathrm{O}(33)-\mathrm{V}(32)-\mathrm{N}(20)$ & 132.271 & $\mathrm{~N}(19)-\mathrm{V}(25)-\mathrm{N}(5)$ & 79.011 & $\mathrm{H}(47)-\mathrm{C}(18)-\mathrm{N}(19)$ & 118.942 \\
\hline N(19)-C(18)-C(17) & 120.26 & $\mathrm{~N}(10)-\mathrm{V}(25)-\mathrm{N}(5)$ & 78.583 & H(47)-C(18)-C(17) & 120.798 \\
\hline $\mathrm{H}(46)-\mathrm{C}(17)-\mathrm{C}(18)$ & 119.657 & $\mathrm{H}(40)-\mathrm{C}(11)-\mathrm{N}(10)$ & 118.766 & $\mathrm{C}(8)-\mathrm{C}(4)-\mathrm{N}(5)$ & 112.816 \\
\hline $\mathrm{H}(46)-\mathrm{C}(17)-\mathrm{C}(16)$ & 120.088 & $\mathrm{C}(12)-\mathrm{C}(11)-\mathrm{N}(10)$ & 120.278 & $\mathrm{C}(8)-\mathrm{C}(4)-\mathrm{N}(3)$ & 125.263 \\
\hline$C(18)-C(17)-C(16)$ & 120.255 & $\mathrm{~V}(25)-\mathrm{N}(10)-\mathrm{C}(11)$ & 122.41 & $\mathrm{~N}(5)-\mathrm{C}(4)-\mathrm{N}(3)$ & 121.915 \\
\hline $\mathrm{H}(45)-\mathrm{C}(16)-\mathrm{C}(17)$ & 120.365 & $\mathrm{~V}(25)-\mathrm{N}(10)-\mathrm{C}(7)$ & 116.836 & $\mathrm{C}(4)-\mathrm{N}(3)-\mathrm{C}(2)$ & 114.782 \\
\hline $\mathrm{H}(45)-\mathrm{C}(16)-\mathrm{C}(15)$ & 120.127 & $\mathrm{C}(11)-\mathrm{N}(10)-\mathrm{C}(7)$ & 120.472 & $\mathrm{C}(9)-\mathrm{C}(2)-\mathrm{N}(3)$ & 120.809 \\
\hline C(17)-C(16)-C(15) & 119.508 & $\mathrm{C}(24)-\mathrm{C}(9)-\mathrm{N}(20)$ & 121.975 & $\mathrm{C}(9)-\mathrm{C}(2)-\mathrm{N}(1)$ & 114.261 \\
\hline $\mathrm{H}(44)-\mathrm{C}(15)-\mathrm{C}(16)$ & 121.003 & $\mathrm{C}(24)-\mathrm{C}(9)-\mathrm{C}(2)$ & 123.754 & $\mathrm{~N}(3)-\mathrm{C}(2)-\mathrm{N}(1)$ & 124.898 \\
\hline $\mathrm{H}(44)-\mathrm{C}(15)-\mathrm{C}(8)$ & 120.485 & N(20)-C(9)-C(2) & 114.268 & V(32)-N(1)-C(6) & 128.009 \\
\hline $\mathrm{C}(16)-\mathrm{C}(15)-\mathrm{C}(8)$ & 118.511 & $\mathrm{~N}(19)-\mathrm{C}(8)-\mathrm{C}(15)$ & 122.152 & $\mathrm{~V}(32)-\mathrm{N}(1)-\mathrm{C}(2)$ & 114.828 \\
\hline $\mathrm{H}(43)-\mathrm{C}(14)-\mathrm{C}(13)$ & 119.524 & N(19)-C(8)-C(4) & 113.446 & $\mathrm{C}(6)-\mathrm{N}(1)-\mathrm{C}(2)$ & 117.143 \\
\hline $\mathrm{H}(43)-\mathrm{C}(14)-\mathrm{C}(7)$ & 121.291 & $\mathrm{C}(15)-\mathrm{C}(8)-\mathrm{C}(4)$ & 124.39 & $C(6)-N(5)-C(4)$ & 122.43 \\
\hline $\mathrm{C}(13)-\mathrm{C}(14)-\mathrm{C}(7)$ & 119.185 & $\mathrm{C}(14)-\mathrm{C}(7)-\mathrm{N}(10)$ & 120.293 & $\mathrm{H}(40)-\mathrm{C}(11)-\mathrm{C}(12)$ & 120.956 \\
\hline $\mathrm{H}(42)-\mathrm{C}(13)-\mathrm{C}(14)$ & 119.946 & $\mathrm{C}(14)-\mathrm{C}(7)-\mathrm{C}(6)$ & 126.988 & $\mathrm{~V}(25)-\mathrm{N}(5)-\mathrm{C}(4)$ & 118.344 \\
\hline $\mathrm{H}(42)-\mathrm{C}(13)-\mathrm{C}(12)$ & 120.164 & $\mathrm{~N}(10)-\mathrm{C}(7)-\mathrm{C}(6)$ & 112.669 & $\mathrm{C}(13)-\mathrm{C}(12)-\mathrm{C}(11)$ & 119.791 \\
\hline $\mathrm{C}(14)-\mathrm{C}(13)-\mathrm{C}(12)$ & 119.889 & $\mathrm{C}(7)-\mathrm{C}(6)-\mathrm{N}(5)$ & 111.964 & $\mathrm{~V}(25)-\mathrm{N}(5)-\mathrm{C}(6)$ & 119.225 \\
\hline $\mathrm{H}(41)-\mathrm{C}(12)-\mathrm{C}(13)$ & 120.267 & $\mathrm{C}(7)-\mathrm{C}(6)-\mathrm{N}(1)$ & 129.696 & & \\
\hline $\mathrm{H}(41)-\mathrm{C}(12)-\mathrm{C}(11)$ & 119.942 & $\mathrm{~N}(5)-\mathrm{C}(6)-\mathrm{N}(1)$ & 118.328 & & \\
\hline
\end{tabular}

